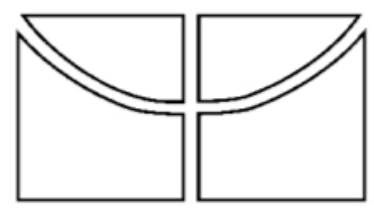

UNIVERSIDADE DE BRASÍLIA FACULDADE DE COMUNICAÇÃO

PROGRAMA DE PÓS-GRADUAÇÃO EM COMUNICAÇÃO

POLÍTICAS CULTURAIS DE ACESSO AO CINEMA NO BRASIL:

OS DESAFIOS DO PROGRAMA CINEMA PERTO DE VOCE

Milena Times de Carvalho 


\author{
UNIVERSIDADE DE BRASÍLIA \\ FACULDADE DE COMUNICAÇÃO \\ PROGRAMA DE PÓS-GRADUAÇÃO EM COMUNICAÇÃO
}

\title{
POLÍTICAS CULTURAIS DE ACESSO AO CINEMA NO BRASIL: \\ OS DESAFIOS DO PROGRAMA CINEMA PERTO DE VOCÊ
}

Milena Times de Carvalho

Dissertação apresentada ao Programa de PósGraduação da Universidade de Brasília/UnB como parte dos requisitos para a obtenção do título de Mestre.

Linha de Pesquisa: Políticas de Comunicação e de Cultura.

Orientadora: Profa. Dra. Elen Cristina Geraldes 


\section{UNIVERSIDADE DE BRASÍLIA \\ FACULDADE DE COMUNICAÇÃO \\ PROGRAMA DE PÓS-GRADUAÇÃO EM COMUNICAÇÃO}

\section{DISSERTAÇÃO DE MESTRADO}

Políticas Culturais de acesso ao cinema no Brasil: os desafios do programa Cinema Perto de Você

Milena Times de Carvalho

Banca Examinadora:

Prof $^{\mathrm{a}}$. Dr ${ }^{\mathrm{a}}$. Elen Cristina Geraldes - FAC/ UnB

Orientadora

Prof $^{\mathrm{a}}$. Dr ${ }^{\mathrm{a}}$. Dácia Ibiapina da Silva - FAC/ UnB

Membro Interno

Prof. Dr. José Walter Nunes - CEAM/ UnB

Membro Externo

Prof $^{a}$. Dr ${ }^{\mathrm{a}}$. Janara Kalline Leal Lopes de Sousa - FAC/UnB

Suplente 
Aos meus pais, Rejane e Sócrates 


\section{AGRADECIMENTOS}

Aos meus pais, a quem dedico esse trabalho, pelo exemplo e por incentivarem, desde as minhas mais remotas lembranças, a leitura, o estudo e uma visão crítica do mundo.

A Giliate, companheiro incondicional de todos os momentos, por todo amor, paciência e dedicação.

A Elen Geraldes, por ser tão cuidadosa e firme durante toda essa jornada. Por compartilhar de forma tão generosa sua experiência e seu conhecimento, imprescindíveis para a concretização desse trabalho. A Dácia Ibiapina, José Walter Nunes, Sivaldo Pereira e Janara Sousa, por se mostrarem tão dispostos a contribuir na qualificação e na defesa.

À Coordenação de Aperfeiçoamento de Pessoal de Nível Superior (Capes), pela bolsa de estudos essencial para o desenvolvimento desta pesquisa. Aos professores e funcionários do Programa, por contribuírem direta ou indiretamente nesse processo. Aos colegas de turma, por compartilhar a caminhada, as angústias, as risadas, a luta por melhores condições de pesquisa. A Mariana Martins, pela amizade, pela acolhida e pelo incentivo desde o início. A todos os meus amigos espalhados pelo mundo, pela eterna torcida e pelos momentos de descontração tão preciosos, presenciais ou à distância. 


\section{RESUMO}

A partir de uma retomada da constituição das políticas públicas voltadas para o setor cinematográfico em vários períodos históricos, é possível constatar que o foco da política de fomento se concentrou primordialmente na etapa de produção dos filmes. Na última década, iniciativas como a Lei do Audiovisual e o Fundo Setorial do Audiovisual conseguiram garantir um significativo montante de recursos que têm contribuído para o crescimento da produção de filmes nacionais. No entanto, o público atingido pela maioria desses filmes ainda representa um percentual pouco expressivo do mercado. Partindo dessa constatação, a presente pesquisa se propõe a investigar como tem sido formulada e implementada no Brasil uma política de acesso ao cinema, por meio de um estudo de caso do programa mais representativo dessa vertente na política em vigor, o Cinema Perto de Você. Adotando o aporte teórico-metodológico da Economia Política da Comunicação e sua aplicação aos estudos sobre a atividade cinematográfica, bem como reflexões contemporâneas sobre a conceituação e caracterização das políticas públicas de cultura e do acesso à cultura, analisamos a perspectiva de acesso adotada pelo Cinema Perto de Você, os atores e relações de poder envolvidos na sua formulação e implementação, e em que medida ele cumpre com o objetivo de diversificar, descentralizar e expandir a oferta de cinema à população brasileira. Concluímos que o programa, se por um lado tem contribuído positivamente para a expansão do parque exibidor, por outro, enxerga o acesso prioritariamente como prática de consumo, reforçando a hegemonia do modelo comercial de produção, distribuição e exibição, o que lhe impede de atuar significativamente na diminuição das desigualdades de acesso e na diversificação do conteúdo oferecido.

Palavras-chave: acesso ao cinema, políticas culturais, Cinema Perto de Você. 


\begin{abstract}
From a resumption of the establishment of public policies for the film industry in various historical periods, it is clear that the focus of the policy focused primarily on the film production. In the last decade, initiatives such as the Audiovisual Law and the Audiovisual Sector Fund managed to secure a significant amount of resources that have contributed to the growth of production of national films, but the audience reached by the majority of these films is still a small percentage of market. Based on this finding, the present study aims to investigate how it has been formulated and implemented in Brazil a cinema access policy, through a case study of the most representative program this strand in the policy in course, the Cinema Perto de Você. Adopting the theoretical and methodological support of the Political Economy of Communication and its application to studies of film activity, as well as contemporary studies on the conceptualization and characterization of public policies on culture and access to culture, we analyzed the perspective of access adopted by the Cinema Perto de Você, the actors and power relations involved in its formulation and implementation, and to what extent it complies with the aim of diversifying, decentralizing and expanding the offer of films to the Brazilian population. We conclude that the program, on the one hand, has contributed positively to the expansion of the exhibitor park, and on the other hand faces the access primarily as a consumption practice, reinforcing the hegemony of the business model of production, distribution and exhibition, which prevents the Cinema Perto de Você from acting significantly in the reduction of inequalities of access and the diversification of the offered content.
\end{abstract}

Key-words: access to cinema, cultural policies, Cinema Perto de Você. 


\section{LISTA DE FIGURAS}

Figura 1 - Fachada do Shopping Hortolândia 34

Figura 2 - Hall de entrada do Cinesystem Hortolândia 34

Figura 3 - Autoatendimento Cinesystem Hortolândia 35

Figura 4 - Bilheteria do Cinesystem Hortolândia no sábado à tarde 36

Figura 5 - Praça de alimentação e entrada do Cine 10

Figura 6 - Bilheteria do Cine $10 \quad 38$

Figura 7 - Mural de cartazes do Cine $10 \quad 39$

Figura 8 - Fachada do Imperial Shopping $\quad 42$

Figura 9 - Entrada do Cinesystem Imperatriz 43 


\section{LISTA DE QUADROS}

Quadro 1 - Resumo da proposta de pesquisa 3

Quadro 2 - Etapas das Políticas Públicas 19

Quadro 3 - Guia de entrevista e análise documental 32

Quadro 4 - Grupos de prioridade do Cinema Perto de Você 59

Quadro 5 - Alcance das metas do Cinema Perto de Você 69

Quadro 6 - Salas de exibição por Região (2010 a 2014) 70

Quadro 7 - Distribuição geográfica de novos complexos beneficiados pelo CPV 71 


\section{LISTA DE GRÁFICOS}

Gráfico 1 - Total de longas lançados por ano (1930-1965) 45

Gráfico 2 - Total de longas lançados por ano (1966-1990) 48

Gráfico 3 - Total de salas de cinema por ano (1969-1990) 48

Gráfico 4 - Incentivo federal ao audiovisual nacional (em milhões) 53

Gráfico 5 - Total de longas lançados por ano (1995-2014) 53

Gráfico 6 - Público do cinema nacional em salas de exibição (1995-2014) 54

Gráfico 7 - Cinema nacional na televisão e vídeo doméstico (2008-2013) 55

$\begin{array}{ll}\text { Gráfico } 8 \text { - Frequência após abertura da nova sala } & 73\end{array}$

$\begin{array}{ll}\text { Gráfico } 9 \text { - Sala que mais frequenta atualmente } & 73\end{array}$

Gráfico 10 - Onde mora em relação à sala $\quad 74$

$\begin{array}{ll}\text { Gráfico } 11 \text { - Meios de transporte mais utilizados } & 74\end{array}$

Gráfico 12 - Opinião sobre o valor dos ingressos $\quad 75$

Gráfico 13 - Se o ingresso fosse mais barato, viria mais vezes? 75

Gráfico 14 - Justificativas entre os que consideram o ingresso barato 76

$\begin{array}{ll}\text { Gráfico } 15 \text { - Opinião sobre a estrutura da sala } & 78\end{array}$

Gráfico 16 - Como escolhe os filmes $\quad 85$

Gráfico 17 - Costuma assistir a filmes nacionais? 86

Gráfico 18 - Opinião sobre os filmes nacionais em geral 86

Gráfico 19 - Opinião quanto à oferta de filmes nacionais nesta sala 88

Gráfico 20 - Opinião sobre a programação da sala 88

Gráfico 21 - Escolaridade dos entrevistados $\quad 89$ 


\section{LISTA DE ABREVIATURAS E SIGLAS}

Ancinav - Agência Nacional do Cinema e do Audiovisual

Ancine - Agência Nacional do Cinema

Concine - Conselho Nacional de Cinema

Condecine - Contribuição para o Desenvolvimento da Indústria Cinematográfica Nacional CPV - Cinema Perto de Você

DIP - Departamento de Imprensa e Propaganda

Embrafilme - Empresa Brasileira de Filmes S/A

Fistel - Fundo de Fiscalização das Telecomunicações

FSA - Fundo Setorial do Audiovisual

GEDIC - Grupo Executivo de Desenvolvimento da Indústria Cinematográfica

IBGE - Instituto Brasileiro de Geografia e Estatística

INC - Instituto Nacional do Cinema

INCE - Instituto Nacional de Cinema Educativo

LCD - Liquid Cristal Display

PIB - Produto Interno Bruto

Recine - Regime Especial de Tributação para o Desenvolvimento da Atividade de Exibição Cinematográfica

SAv - Secretaria do Audiovisual 
RESUMO vi vi

ABSTRACT vii

LISTA DE FIGURAS viii

LISTA DE QUADROS Ix

LISTA DE GRÁFICOS $\quad$ X

LISTA DE ABREVIATURAS E SIGLAS xi

1. INTRODUÇÃO

2. REFERENCIAL TEÓRICO-METODOLÓGICO 9

2.1. Economia Política do Cinema 9

2.2. Os conceitos de política pública de cultura e Estado 16

2.3. $\mathrm{O}$ conceito de acesso à cultura 23

2.4. Procedimentos metodológicos 29

2.5. Dados gerais da pesquisa de campo 33

3. POLÍTICAS DE CINEMA NO BRASIL 44

3.1. Da cota de tela à Embrafilme 44

3.2. Do desmonte da Embrafilme à Retomada 48

3.3. Da verdadeira retomada da produção aos desafios da difusão e do acesso 52

4. A ATUAÇÃO dO CINEMA PERTO DE VOCÊ NO ACESSO E A HEGEMONIA DO CINEMA COMERCIAL

4.1. Acesso material e a hegemonia do modelo de exibição multiplex 65

4.2. Acesso cultural e simbólico e a hegemonia dos grandes produtores de conteúdo 83

5. CONSIDERAÇÕES FINAIS 94

6. REFERENCIAS

6.1. Referências bibliográficas $\quad 98$

6.2. Entrevistas 103

6.3. Páginas eletrônicas 104

7. APÊNDICE 105 


\section{INTRODUÇÃO}

A presente pesquisa propõe-se a investigar como tem sido formulada e implementada no Brasil uma política de acesso ao cinema, a partir de um estudo de caso do programa mais representativo desta vertente da política cinematográfica em vigor, o Cinema Perto de Você. Partimos de uma retomada histórica de como se constituíram as políticas públicas voltadas para o cinema no Brasil e adotamos o referencial teóricometodológico da Economia Política da Comunicação para abordar nosso objeto, na tentativa de construir uma reflexão acerca do conceito de acesso, de compreender qual a perspectiva de acesso adotada pelo programa e que interesses, atores e relações de poder estão envolvidos na sua formulação e implementação, além de avaliar em que medida ele cumpre com seus objetivos. Acreditamos que isso nos permitirá lançar um olhar sobre uma etapa pouco estudada do processo, tanto da constituição das políticas de incentivo, quanto da própria atividade cinematográfica, uma vez que a tríade produção-distribuição-exibição tende a ser o foco das investigações na área.

No fim da década de 1980, com a extinção da Embrafilme, empresa estatal responsável pela produção e distribuição da maior parte dos filmes nacionais naquele momento, as políticas voltadas para o audiovisual no Brasil, durante a década seguinte, concentraram-se em leis e mecanismos de incentivo via isenção fiscal (Lei Rouanet e Lei do Audiovisual). Após a lacuna de política cultural do governo Fernando Collor de Mello, que em 1990 extinguiu as leis de incentivo e os órgãos culturais no país, saímos de uma média de mais de 80 produções por ano, durante as décadas de 1970 e 1980, para menos de 10 lançamentos anuais na primeira metade da década de 1990. Com a Lei do Audiovisual, a produção nacional voltou a crescer e gerou certa euforia no setor durante o período que ficou conhecido como Retomada. As contradições da nova política de incentivo, entretanto, não tardaram a aparecer: criados para incentivar a iniciativa privada a investir em cultura, os mecanismos de isenção fiscal acabaram aumentando a proporção de verba pública investida em relação à verba privada, além de privilegiar os produtores que tinham mais capacidade de captação junto às empresas.

Em meio à crise, que se agravou com a privatização das empresas de telecomunicações, tradicionais investidoras do cinema brasileiro, o setor voltou a se organizar e realizou o III e o IV Congresso Brasileiro de Cinema, em 2000 e 2001, nos 
quais se reivindicou a elaboração de uma política audiovisual mais abrangente e contínua. Para atender às demandas, o governo estabeleceu o Conselho Superior de Cinema e criou a Agência Nacional do Cinema (Ancine), responsável pelo fomento, regulação e fiscalização do setor. Criada em 2001, a Ancine só começou a funcionar efetivamente em 2003, já durante o governo Lula, contando com recursos da Contribuição para o Desenvolvimento da Indústria Cinematográfica Nacional (Condecine), taxa sobre a publicidade e o cinema (nacional e estrangeiro) comercializados no Brasil.

Nos últimos dez anos, além da consolidação das leis de incentivo via renúncia fiscal, os programas de fomento da SAv e, mais recentemente, a criação do Fundo Setorial do Audiovisual, que contempla o estímulo a diversos segmentos da cadeia produtiva do setor, vêm contribuindo consideravelmente para o crescimento e estabilização da produção cinematográfica no país, além de trazer de volta para o âmbito do Estado a decisão do destino de parte da verba pública de incentivo ao cinema. O crescimento verificado na produção, contudo, não se reflete em um aumento de público e de locais e suportes de exibição na mesma intensidade.

Uma política cultural eficaz não pode se concentrar apenas nos meios de produção, mas deve garantir também os meios de difusão, pois uma política pública só atinge sua finalidade quando consegue promover amplamente o acesso a um bem ou serviço considerado um direito essencial para o bem-estar e para a vivência cidadã de uma população. Diante do cenário descrito e após pesquisa exploratória de todas as iniciativas federais que constituem as políticas públicas do audiovisual no Brasil, consagradas em leis de incentivo ou em programas de fomento, foi possível constatar que, embora as leis de incentivo e as linhas de ação do FSA atuem também nos setores de distribuição e exibição, o Cinema Perto de Você (CPV) é o principal programa atualmente em funcionamento voltado exclusivamente para a ampliação do acesso ao cinema.

Para a seleção do objeto de estudo, levamos em consideração apenas as políticas federais, por conta do seu potencial de abrangência nacional, já que as intervenções estaduais ou municipais, além de muito diversas, normalmente apresentam reflexo local ou regional. Além disso, a escolha do objeto levou em consideração alguns requisitos que eram mais bem atendidos pelo CPV que por outras iniciativas: (a) a duração e continuidade do programa, já que incentivos muito recentes ou que foram interrompidos não permitiriam uma análise mais aprofundada; (b) o acesso a dados relativos ao aporte financeiro 
empregado, quantidade e identificação dos projetos contemplados e resultados alcançados; (c) quantidade mínima de projetos contemplados, para uma melhor identificação de suas características e tendências.

Instituído pela Lei 12.599/2012, o programa Cinema Perto de Você visa a diversificar, descentralizar e expandir a oferta de serviços audiovisuais para a população brasileira por meio da ampliação do parque exibidor de cinema, fortalecendo as empresas e o segmento de exibição cinematográfica e facilitando o acesso às obras audiovisuais por meio da abertura de salas em cidades de porte médio e em bairros populares das grandes cidades. O Quadro 1 resume o objeto e os propósitos desta investigação:

\section{Quadro 1 - Resumo da proposta de pesquisa}

\begin{tabular}{|l|l|l|}
\hline 1. & A pesquisa se propôs a... & $\begin{array}{l}\text { Investigar a formulação e a implementação do programa } \\
\text { Cinema Perto de Você a partir de uma abordagem } \\
\text { teórico-metodológica da Economia Política da } \\
\text { Comunicação. }\end{array}$ \\
\hline 2. & Para... & $\begin{array}{l}\text { Entender qual a perspectiva de acesso adotada e quais os } \\
\text { interesses, atores e relações de poder envolvidos neste } \\
\text { processo. }\end{array}$ \\
\hline 3. & Com a finalidade de... & $\begin{array}{l}\text { Explicar de que maneiras o programa, enquanto } \\
\text { representante característico das políticas públicas vigentes } \\
\text { voltadas para o audiovisual no Brasil, contribui para o } \\
\text { acesso da população ao cinema, inclusive o cinema } \\
\text { nacional. }\end{array}$ \\
\hline 4. & O que permitiu... & $\begin{array}{l}\text { Lançar um olhar sobre o acesso, que constitui tanto um } \\
\text { conceito quanto uma etapa do processo pouco estudados, } \\
\text { e refletir sobre sua importância e relevância na política } \\
\text { cultural do cinema. }\end{array}$ \\
\hline
\end{tabular}

Fonte: Elaboração própria.

Para alcançar esses objetivos, adotamos como procedimento metodológico o estudo de caso, com realização de entrevistas semiestruturadas com os principais atores envolvidos, análise documental dos marcos legais do programa, do site e dos relatórios da Ancine e revisão bibliográfica.

A grande maioria das pesquisas sobre cinema no Brasil aborda características técnicas ou estéticas dos filmes brasileiros, do seu uso como representação de algum símbolo social ou histórico. Como aponta André Gatti (2007), até a distribuição comercial é um assunto relativamente novo nos estudos sobre o cinema brasileiro: "A nossa tradição 
neste campo de estudo ainda engatinha em relação aos seus congêneres, como por exemplo a história da produção de filmes nacionais, onde temos estudos críticos, sociológicos, históricos etc." (GATTI, 2007, p.9).

Sob a perspectiva do estudo do mercado, a partir da Retomada é possível perceber um maior interesse dos pesquisadores em entender a posição do audiovisual nacional dentro dos novos contextos e sistemas de captação de recursos, produção, distribuição e exibição. Já a maioria dos estudos sobre política cultural na área audiovisual foca-se nos marcos legais e institucionais que tivemos no Brasil ao longo da história, voltando-se principalmente para a análise dos contextos político-sociais de cada marco.

João Paulo Matta (2004) analisa a performance competitiva do cinema brasileiro no mercado nacional de salas de cinema, entre 1994 e 2003, a partir de um estudo de caso dos filmes Janela da Alma e Cidade de Deus. Ele identifica como principais fatores que condicionaram o incremento de competitividade: o crescimento e a manutenção de um fluxo anual de lançamentos, com a eficiência da distribuição alavancada pela adesão de grandes companhias estrangeiras ao incentivo fiscal; o aprimoramento da qualidade e a diversidade das produções nacionais; o movimento de integração entre a televisão e o cinema, a partir da criação da Globo Filmes; a presença de astros e estrelas da televisão nos lançamentos; o crescimento do parque nacional de salas de exibição.

Aletéia Selonk (2004) estuda a distribuição cinematográfica no Brasil, buscando os principais agentes, práticas e políticas do setor no período de 1896 a 2002. Demonstra que o processo de estruturação do setor é historicamente baseado na atuação de agentes privados e públicos, mas que a política cinematográfica desenvolvida no país contemplou tardiamente a distribuição.

Gatti (2005) analisa o estabelecimento do mercado cinematográfico brasileiro durante a Retomada a partir das suas relações com os incentivos estatais e com a televisão, especialmente após a criação da Globo Filmes. Para análise da distribuição, foca nos casos de três distribuidoras (Columbia Pictures, Riofilme e Lumière), além da comercialização de Cidade de Deus e Central do Brasil. Já para a análise da exibição, toma o caso da Cinemark, enquanto representante de uma lógica de exibição transnacional baseada nos multiplexes, ${ }^{1}$ e da Estação Botafogo, enquanto marco de um modelo de exibição preocupado com questões culturais.

\footnotetext{
${ }^{1}$ Complexos de salas de cinema localizadas em shopping centers, inicialmente ligadas a conglomerados de
} 
Danielle Borges (2007) foca na configuração da indústria cinematográfica brasileira entre 1995 e 2005 e aponta que, na produção, os investimentos financeiros se concentraram nas mãos de produtores historicamente estabelecidos; na distribuição, empresas estrangeiras detêm, com poucos lançamentos, a maior fatia do mercado nacional; na exibição, há o domínio exercido por três empresas, duas delas internacionais, além da concentração das salas nos centros urbanos, o aumento dos preços dos ingressos e a relação entre acesso e situação socioeconômica. Rodrigo Michel (2011) apresenta uma abordagem semelhante, porém estende o seu período de análise até 2009 , o que lhe permite mencionar programas como Cinema Perto de Você, Procult e as linhas de ação do FSA, mas sem aprofundar a análise em virtude de serem muito recentes.

Melina Marson (2006) analisa o período da Retomada a partir da relação entre o campo cinematográfico e o Estado, em um processo que se iniciou com uma euforia do retorno da atividade, até a crise do modelo de incentivo fiscal, que culminou com os dois congressos brasileiros de cinema e a criação da Ancine, passando também pela tentativa de criação da Ancinav (Agência Nacional do Cinema e do Audiovisual), que previa a elaboração de uma política de multimídia que envolvesse cinema, vídeo, televisão e publicidade.

Lia Bahia (2009) também trata da relação do Estado com a industrialização do cinema brasileiro, porém foca nos anos 2000. Tenta compreender as implicações mútuas entre as dimensões simbólicas, econômicas e políticas inerentes ao setor, a partir da ambiguidade de uma atividade que é ao mesmo tempo industrial e fenômeno cultural, estético e artístico. A partir de uma revisão histórica, mostra como o cinema brasileiro sempre esteve atrelado à política estatal de cultura, embora variassem a forma, as motivações e as implicações dessa relação. Ela utiliza categorias analíticas como indústria cultural, cinemas nacionais, mercado, Estado e globalização e aponta que a construção da relação entre cinema e Estado no país teve foco excessivo na produção, o que levou ao obscurecimento da dimensão industrial pela ausência de visão sistêmica: "optou-se por patrocinar a produção e não abrir conflito com os poderosos agentes do mercado audiovisual" (BAHIA, 2009, p.174).

mídia internacionais, que apresentam atualização tecnológica mais frequente que as salas de cinema tradicionais. 
Carla Camargos (2011) adentra o ambiente legislativo e analisa, entre os anos de 1999 e 2010, as disputas em torno da adoção de medidas legais que contemplem a exibição da produção audiovisual nacional independente pela televisão, veículo que tradicionalmente rejeita regulamentação em nosso país. Mostra que o setor cinematográfico, especialmente no final da década de 1990, passa a se interessar pela presença na televisão, quando esta começou a ser vista como essencial para a sustentação da atividade. Do ponto de vista teórico-metodológico, adota o conceito de hegemonia segundo Antonio Gramsci, e entende a ação dos produtores independentes, na condição de atores constitutivos do processo de construção da política setorial, como uma guerra de posições. Utiliza também o conceito de formações de Raymond Williams, tentando identificar quais são as formações em disputa no interior do campo audiovisual brasileiro e como elas se relacionam entre si, com o Estado e com a sociedade em geral.

Marcelo Ikeda (2011) descreve e analisa as políticas públicas federais para o setor cinematográfico implementadas no Brasil a partir da década de 1990. Primeiramente, as políticas associaram-se às transformações do próprio papel do Estado, refletindo a crise de um Estado intervencionista e a recuperação do ideário liberal. No início dos anos 2000, desenha-se um novo modelo institucional com a criação da Ancine, que apresenta, no entanto, limitações legais para sua plena atuação, inviabilizando a consolidação de uma indústria audiovisual autossustentável. Para Ikeda, em vez de uma política de ocupação do mercado audiovisual, houve apenas uma política de produção de longas-metragens. Ao final de sua análise, ele mostra outros paradoxos da política vigente a partir da implementação dos mecanismos automáticos de fomento, com alterações nos mecanismos de incentivo fiscal e a criação do Fundo Setorial do Audiovisual.

Karine Ruy (2011) apresenta uma análise sobre a circulação dos filmes brasileiros de longa-metragem no mercado interno de salas entre 2000 e 2009 e identifica os fatores que interferiram no sucesso comercial de alguns filmes nacionais lançados nessa época, que registraram mais de um milhão de espectadores no mercado de salas.

Nair Rúbia Baptista (2012) estuda as políticas cinematográficas na Venezuela a partir de 2005, durante o governo Chávez, observa a reforma da regulamentação do setor e levanta as consequências da nova política pública cultural implementada. Apesar do foco da dissertação ser o contexto venezuelano, a proposta aqui apresentada assemelha-se à trajetória de pesquisa de Batista, pois ela trabalha sob o ponto de vista teórico- 
metodológico da Economia Política da Comunicação e sua aplicação ao estudo do cinema, bem como com os conceitos de Estado ampliado a partir de Gramsci e de políticas públicas de cultura sob a perspectiva analítica proposta por Rubim (2007).

Todos esses estudos contribuíram para a contextualização deste trabalho, bem como para o diagnóstico de que o estudo da política cinematográfica, sob o ponto de vista do acesso, demanda um aprofundamento. Mesmo as pesquisas sobre distribuição e exibição na última década levam em conta principalmente dados de mercado, e a análise das leis de incentivo e do fomento direto é feita primordialmente sob o prisma da produção. As menções aos programas e mecanismos voltados para o acesso são isoladas, mesmo porque se trata de iniciativas recentes, e a perspectiva do público é pouco considerada. De forma geral, todas as pesquisas apresentam um resgate histórico do campo cinematográfico no Brasil. Em alguns casos, a partir do início das atividades no setor; em outros, tomando o desmonte da Embrafilme ou o estabelecimento das políticas de incentivo fiscal como marco inicial. Embora com perspectivas variadas de análise, é recorrente a menção ao estabelecimento da Globo Filmes como marco que vai interferir em todos os elos da cadeia produtiva no Brasil. No caso da distribuição e exibição, a presença ostensiva de empresas estrangeiras também é apontada como fator de poderosa influência sobre a penetração do filme brasileiro no mercado e sobre a limitação do alcance das políticas implementadas.

Do ponto de vista metodológico, embora vários trabalhos não apresentem um referencial teórico-metodológico demarcado, nem explicite de forma clara os procedimentos utilizados, foi possível constatar que a maioria baseia-se primordialmente em revisão bibliográfica e análise de dados. Alguns tomam a abordagem de estudo de caso, e a maior parte também se utiliza de entrevistas com atores implicados na análise. Neste sentido, a partir da pesquisa de campo e das entrevistas com os beneficiados pelo CPV, acreditamos que podemos oferecer também uma outra abordagem possível do tema.

De forma mais ampla, embora tratem de um momento histórico específico, que vai até o final da década de 1960, foram imprescindíveis as contribuições de Anita Simis (2008), com Estado e cinema no Brasil, e Ecléa Bosi (1981), com Cultura de massas e cultura popular: leitura de operárias. A primeira nos inspira não só por seu minucioso trabalho de resgate de dados, e principalmente pela preocupação permanente de contextualizá-los em seus momentos históricos e de levantar suas repercussões, o que permite traçar um aprofundado panorama das relações entre cinema e Estado até 1966, 
respeitando a complexidade dos processos. A segunda, ao estudar as relações entre a cultura de massa e a cultura popular a partir da análise dos hábitos de leitura de jovens operárias paulistas em 1970, nos mostra os caminhos possíveis de incluir o público, com seus hábitos e visões particulares, como elemento que agrega outras dimensões ao objeto de estudo, ao mesmo tempo que nos impõe o exercício de deslocar nosso próprio ponto de vista.

O próximo capítulo é dedicado ao referencial teórico-metodológico desta pesquisa. A partir das contribuições da Economia Política da Comunicação, levantamos as principais posturas e conceitos que guiaram o desenvolvimento do trabalho para, em seguida, traçar uma revisão dos conceitos específicos de política pública de cultura, Estado e acesso, enquanto concepções e parâmetros de análise. Ainda no mesmo capítulo, esclareceremos os procedimentos de pesquisa delineados para alcançar nossos objetivos, bem como suas limitações.

O terceiro capítulo realiza um breve resgate histórico das políticas voltadas para o cinema no Brasil, já que encaramos as políticas atuais como produto de um longo processo político, econômico e social que não se explica sem esse retorno. Analisaremos como essas relações se estabeleceram ao longo do tempo, como cada momento gerou condições para avanços e retrocessos e como se constituíram a atual política e o atual cenário em que se insere o programa Cinema Perto de Você.

Por fim, o quarto capítulo propõe-se a interpretar os dados recolhidos na pesquisa documental e na pesquisa de campo a partir da construção dos conceitos-chave de acesso material e acesso cultural e simbólico, e também a partir dos processos de mercantilização, espacialização e estruturação apontados por Mosco (2009) como os principais pontos de entrada para uma análise da Economia Política da Comunicação hoje. Dessa forma, traçamos os méritos e limitações do Cinema Perto de Você e propomos uma reflexão acerca de como o acesso tem sido encarado pelas políticas públicas de cultura. 


\section{REFERENCIAL TEÓRICO-METODOLÓGICO}

\subsection{Economia Política do Cinema}

Pertencente à tradição do pensamento crítico desenvolvido a partir do legado de Karl Marx, a Economia Política da Comunicação (EPC) é um constructo teóricometodológico que apresenta como foco de análise as relações de poder que se expressam no sistema econômico, na cultura e nas suas interações. Nesse sentido, possui uma origem comum à dos estudos culturais, porém não abandona categorias fundamentais do pensamento marxista para o estudo da sociedade, como a de classes sociais, e rejeita a naturalização das relações capitalistas, o que se tornou uma tendência em parte das abordagens desses estudos. Como afirmam Brittos, Bolaño e Rosa (2010, p.1), “coube em grande parte aos grupos organizados, nas diferentes associações de pesquisadores do campo da Comunicação em torno da EPC, preservar e desenvolver esse legado crítico ao longo das duas últimas décadas do século passado".

Wasko (2006) defende que o cinema é uma forma de comunicação mediada e que grande parte do aporte teórico da EPC aplicado ao estudo de outros meios pode ser utilizado também para os estudos sobre cinema, objeto que de maneira geral não é encarado pela pesquisa acadêmica como instituição econômica e como meio de comunicação. É nessa perspectiva que aqui apresentamos o arcabouço teórico da EPC como instrumento teórico-metodológico para o estudo das relações entre o setor cinematográfico brasileiro e o Estado, do ponto de vista do acesso ao conteúdo audiovisual.

De acordo com Mosco (2006), duas definições abarcam o amplo leque de abordagens específicas e gerais da disciplina. Em sentido estrito, a Economia Política é o estudo das relações sociais, particularmente as relações de poder, que constituem mutuamente a produção, distribuição e consumo de recursos, incluindo os recursos de comunicação.

Esta formulação tem um certo valor prático porque chama a atenção sobre como opera o negócio da comunicação, por exemplo, como os produtos comunicacionais transitam através de uma cadeia, de produtores a distribuidores, comerciantes e consumidores, cujas compras, alugueis e atenções alimentam novos processos de produção. (MOSCO, 2006, p.59, tradução nossa) 
Já em um sentido mais amplo, a Economia Política pode ser definida como o estudo do controle e da sobrevivência na vida social. O controle refere-se à organização interna de membros de um grupo social e ao processo de adaptação à mudança. Sobrevivência significa como os indivíduos produzem o que é necessário para a continuidade e reprodução social. A partir dessa leitura, os processos de controle são, em termos gerais, políticos, pois constituem a organização social das relações na comunidade. Já os processos de sobrevivência são principalmente econômicos, porque dizem respeito a processos de produção e reprodução.

Tanto Mosco (2006) quanto Wasko, Murdock e Souza (2011) ressaltam quatro ideias centrais que diferentes escolas de pensamento da Economia Política tendem a compartilhar, em contraposição às análises da cultura e da comunicação produzidas pela maioria dos economistas. A primeira é a colocação da história em primeiro plano, ou seja, a tentativa de entender a mudança social enquanto transformação histórica. Em vez de se concentrar somente ou prioritariamente em eventos imediatos, a Economia Política defende que uma compreensão completa das mudanças contemporâneas deve ser baseada na análise de transformações e contradições que se desenvolvem ao longo do tempo. Após a tendência dos economistas ortodoxos de deixarem de lado a preocupação com as dinâmicas da história e as mudanças sociais, transformando a Economia Política em uma ciência exata da economia, os economistas políticos contemporâneos dão continuidade à tradição da Economia Política clássica de considerar a mudança social e a transformação, centrando-se em áreas como a transição de uma economia industrial a uma economia de serviços ou informacional. O estudo dos meios massivos e das tecnologias da comunicação assume um papel importante nesta investigação, porque as indústrias que abarcam esses campos de estudo são forças muito importantes na criação da economia atual.

A segunda ideia é a de totalidade das relações sociais, ou de um posicionamento holístico. Em vez de tratar a economia como um domínio especializado e delimitado, a Economia Política tenta construir uma unidade analítica do político e do econômico, ao dar conta de sua influência mútua e de suas relações com esferas de atividade social mais amplas e simbólicas, ou seja, como se relacionam o poder e a riqueza e como estes influenciam o sistema de meios massivos, de informação e entretenimento. Contudo, mesmo que se pense sobre como a comunicação é socialmente construída, é preciso refletir também sobre o papel da comunicação na construção do social: 
A comunicação não é simplesmente um efeito de práticas sociais, não é apenas a descrição de um panorama cultural que pode ser somente explicado pela economia, ciência política e sociologia. [...] É igualmente importante pensar em como as práticas de comunicação, incluindo os comunicadores e as ferramentas que eles usam, constroem um mundo social e cultural que inclui mitos e símbolos. (MOSCO apud BRITTOS et al, 2010, p.2)

Em terceiro lugar, a Economia Política é comprometida com uma filosofia moral, entendida tanto como interesse nos valores que ajudam a criar o comportamento social, quanto como os princípios morais que deveriam guiar os esforços para modificá-lo. Em contraste com a economia, que se afastou da filosofia moral na tentativa de se apresentar como uma ciência objetiva, a Economia Política permanece centralmente preocupada com as relações entre a organização da cultura e das comunicações e a constituição de uma sociedade fundada na justiça social e na prática democrática. A Economia Política contemporânea tende a favorecer pontos de partida filosófico-morais que promovem a expansão da democracia a todos os aspectos da vida social, não apenas ao aspecto político, assim como a igualdade de acesso à educação e a participação pública plena na produção cultural, além da garantia do direito de se comunicar livremente.

Finalmente, ao contrário das posições acadêmicas tradicionais que separam a esfera da investigação da esfera da intervenção social, os economistas políticos entendem a vida intelectual como uma forma de transformação social e a intervenção social como uma forma de conhecimento. A divisão entre investigação e ação seria artificial e deve ser superada. A análise crítica coloca seus praticantes sob a obrigação de seguir a lógica de suas análises por meio da ação prática em prol da mudança.

Apesar da grande quantidade de estudos filiados à disciplina, Mosco (1996) ressalta que a tendência dos estudos de olharem sempre adiante afastou os pesquisadores de uma reflexão epistemológica mais aprofundada. $\mathrm{Na}$ sua proposta de repensar e renovar a abordagem da Economia Política da Comunicação, ele defende que a disciplina necessita estar fundada em uma epistemologia realista, inclusiva, constitutiva e crítica. Realista ao rejeitar subjetivismos e idealismos extremos, mantendo a possibilidade de compreender a realidade por meio da combinação de métodos empíricos e teóricos, enxergando a realidade como constituição mútua entre observação sensorial e práticas explanatórias. Inclusiva porque, "sem defender uma teoria pluralista do conhecimento que aceita a validade de qualquer modelo interpretativo, essa abordagem está aberta a um leque de quadros explicativos e rejeita a visão de que toda realidade é reduzível a uma força causal 
específica" (MOSCO, 1996, p.137, tradução nossa). Constitutiva porque reconhece as limitações da determinação causal, inclusive da suposição de que as unidades de análise social interagem como totalidades formadas e de maneira linear. Assim, enfoca a vida social como um conjunto de processos mutuamente constitutivos, que atuam uns sobre os outros em vários estágios de formação. Crítica porque entende que o conhecimento é produzido por um processo de comparação, tanto entre diferentes formulações teóricas, quanto entre aspectos de uma dada formulação, e entre os componentes que constituem mutuamente a prática intelectual. Em uma atualização, dez anos mais tarde, Mosco ressalta: "Repensar a economia política também enfatiza a mudança social, os processos sociais e as relações sociais, acima da tendência tradicional da economia política de partir das estruturas sociais e das instituições" (MOSCO, 2006, p.58, tradução nossa).

Para Mosco, são três os processos que constituem os principais pontos de partida para a pesquisa na Economia Política. O primeiro é a mercantilização, ou seja, o processo de transformar coisas valorizadas por seu uso em produtos comercializáveis que são caracterizados pelo seu valor de troca. Na pesquisa em comunicação, a mercantilização adquire um duplo significado: as práticas e tecnologias da comunicação contribuem para o processo geral de mercantilização na sociedade, e a mercantilização é um ponto de partida para entender instituições e práticas específicas da comunicação. A Economia Política da Comunicação destacou-se por sua ênfase em descrever e examinar o significado das instituições, especialmente empresas e governos, responsáveis pela produção, distribuição e intercâmbio das mercadorias da comunicação e pela regulação do mercado de comunicação.

O segundo processo é o que Mosco chama de espacialização, que consiste na transcendência dos limites do espaço geográfico principalmente pelos meios massivos e pelas tecnologias de comunicação. Atualmente, os economistas políticos diriam que, mais que aniquilar o espaço, o comércio, ajudado pelo desenvolvimento das tecnologias da comunicação e da informação, transforma o espaço. A comunicação é central para a espacialização porque os processos de comunicação e informação e as tecnologias promovem a flexibilidade e o controle. A Economia Política da Comunicação tratou tradicionalmente a espacialização como a extensão institucional do poder corporativo na indústria da comunicação, por meio de dois tipos de concentração: a horizontal, quando uma empresa de uma linha de negócios adquire interesse majoritário em outra operação 
midiática que não está diretamente relacionada ao negócio original; ou vertical, quando uma empresa estende seu controle sobre as outras empresas da linha de produção.

Por fim, a estruturação é o processo de construir estruturas como resultado da ação social, de criar relações sociais. A Economia Política descreve como o acesso aos meios massivos e às novas tecnologias da comunicação está influenciado pelas desigualdades de renda e riqueza. A investigação baseada na estruturação ajuda a equilibrar a tendência na análise político-econômica a concentrar-se nas estruturas, tipicamente instituições empresariais e governamentais, pela incorporação de ideias com ação, processo social e prática social. Para Mosco, uma das atividades mais importantes na estruturação é o processo de construção de hegemonia, isto é, uma rede viva de significados e valores mutuamente constituídos que, enquanto experimentados como práticas, manifestam-se confirmando-se reciprocamente. As tensões e conflitos internos dos diversos processos de estruturação, por outro lado, abrem caminho para a formação de posições contrárias e alternativas às ideias e práticas hegemônicas.

Wasko, Murdock e Souza (2011) afirmam que o capitalismo tornou-se um fenômeno generalizado, colocando a globalização dos mercados como um tema central. Paralelamente, a tensão entre os interesses privados e o bem público intensificou-se. Enquanto os esforços das políticas públicas são pressionados, a privatização é crescente e o abuso do poder privado é naturalizado. Uma Economia Política crítica é essencial para entender esses desenvolvimentos, assim como para compreender a comunicação e a mídia contemporâneas, já que a cultura ou as indústrias criativas ocupam hoje um papel central na economia, não sendo mais periféricas.

Conforme apontam Bolaño, Mastrini e Herscovici (1999), em uma retrospectiva dos estudos da EPC na América Latina, desde a década de 1970, o acesso e a participação eram aspectos-chave. Naquele momento, a ampliação do acesso era entendida como expansão da cobertura midiática, em uma tentativa de inclusão das populações menos favorecidas, e o conceito de participação partia do projeto político de integrar setores populares nas políticas de metas, ou mesmo da identificação com a ideologia do mercado, entendendo que a realização da participação se daria por meio da inclusão no consumo.

Diante desse panorama, acreditamos que é cada vez mais necessário propugnar por uma economia política da comunicação que resgate as análises sobre as relações de poder, restaure a discussão sobre o problema da estratificação e das desigualdades de classe e, em termos gerais, que não deixe de estar atenta à 
análise das condições de produção, distribuição e intercâmbio da indústria cultural. (BOLAÑO; MASTRINI; HERSCOVICI, 1999, p.10)

Nesse sentido, os estudos da Economia Política da Comunicação afastam-se da compreensão de certas análises marxistas que, a partir de uma aceitação acrítica do modelo base-estrutura, entendem os meios de comunicação como instrumentos do domínio das classes que estão no poder. Embora reconheça a importância da estrutura econômica no funcionamento dos meios, a EPC tenta não adotar uma perspectiva de transferência mecanicista dos efeitos dos meios. Da mesma forma, a EPC distancia-se das teorias que proclamam uma autonomia excessiva dos níveis ideológico ou político e eliminam qualquer influência das relações econômicas no processo de significação.

Para os autores, um dos atuais desafios para os estudos da Economia Política da Comunicação é analisar, no contexto da emergência dos meios eletrônicos e das telecomunicações controlados por grandes corporações multinacionais, como se organiza a produção para os novos mercados da informação segmentados e específicos e como a comunicação participa do processo de acumulação do capital e das necessidades da estrutura econômica baseada na rapidez do consumo.

\footnotetext{
Nessas condições, o estudo da economia das redes e das novas tecnologias de informação e comunicação adquire uma relevância política fundamental, apontando para as novas modalidades de exclusão social e reforçando a importância dos enfoques como os da Economia Política da Comunicação. (BOLAÑO; MASTRINI; HERSCOVICI, 1999, p.18)
}

A dicotomia entre o público e o privado traduz as relações de força entre os diferentes grupos que compõem a sociedade, e o Estado coloca-se como o ente que limita a apropriação privada desses bens. De acordo com os autores, o caráter público ou privado de um bem não se define em função das características técnicas dos produtos ou dos mercados, mas é o resultado de decisões políticas, de posicionamentos e medidas relacionadas a modalidades de distribuição e acesso ao bem. A lógica privada é a de exclusão parcial ou total pelos preços, enquanto a lógica do serviço público é a de inclusão universal ou de solidariedade tarifária. Em um mundo globalizado, há novas modalidades de exclusão que não se pautam mais unicamente no antagonismo entre centro e periferia, mas na forma diferenciada de acesso às novas tecnologias e plataformas de comunicação pelos diferentes grupos sociais. 
O estudo dos meios massivos e tecnologias da comunicação, incluso o campo de produção e difusão do audiovisual, com suas disputas econômicas e ideológicas, e enquanto espaço de representação e de construção de identidades, assume um papel preponderante para a compreensão das sociedades contemporâneas, especialmente porque:

Os conteúdos audiovisuais produzidos por um país integram um complexo arranjo de bens materiais e imateriais que constituem o imaginário social de uma nação e que contribuem para a conformação de uma soberania cultural nacional. No plano material, o cinema integra uma das mais importantes indústrias culturais da contemporaneidade, capaz de gerar postos de trabalho e outros capitais importantes na dinâmica econômica e produtiva. (BAPTISTA, 2012, p.36)

Para Wasko, Murdock e Souza (2011), a imagem estandardizada e comercial que Adorno conferia à Indústria Cultural está sendo substituída pela emergência de uma indústria criativa. No contexto do capitalismo avançado, os governos enxergam as indústrias de mídia e informação como elementos centrais na economia.

\footnotetext{
Mas ao invés de partir da tecnologia e perguntar quais os seus possíveis impactos, a análise crítica parte da distribuição de poder dominante e da desigualdade para perguntar que interesses vão ser melhor servidos por essas novas potencialidades. Nessa perspectiva, a mídia digital surge não como um nível primário de mudança, mas como um novo campo de batalha de uma luta dominada por antigas batalhas e combatentes. (WASKO; MURDOCK; SOUZA, 2011, p.5, tradução nossa)
}

Segundo Wasko, ao unir uma análise econômica e política, a EPC é capaz de oferecer uma base para leituras ideológicas e análises culturais:

\begin{abstract}
Para a análise completa da comunicação, é necessário conhecer as inter-relações entre as indústrias da comunicação e os centros de poder na sociedade, e seu conhecimento ajuda a dissipar alguns lugares comuns e mitos sobre nosso sistema político e econômico, como os conceitos de pluralismo, livre empresa, concorrência etc. Por meio do estudo da propriedade e do controle, a Economia Política analisa as relações de poder e confirma um sistema de classes e uma desigualdade estrutural. (WASKO, 2006, p.98, tradução nossa)
\end{abstract}

A perspectiva teórico-metodológica da Economia Política da Comunicação, dessa forma, contempla as questões desta pesquisa, ao permitir a análise do setor cinematográfico no Brasil a partir de várias dimensões mutuamente constitutivas: a econômica (materializada pelo mercado), a política (por meio da esfera normativa e regulatória) e a cultural (enxergando a produção audiovisual enquanto poder simbólico e 
representação cultural). A partir do ponto de vista da indústria cinematográfica estadunidense, Wasko (2006) defende que a Economia Política do Cinema deve entender os filmes como mercadorias produzidas e distribuídas dentro de uma estrutura industrial capitalista. No Brasil, embora não se possa falar propriamente em uma indústria do cinema, as relações de produção, distribuição e exibição também estão inseridas no contexto social, econômico e político geral e, portanto, também refletem e reproduzem as estruturas de poder.

Adotando este método, nos propusemos a investigar como se constituíram historicamente as políticas públicas voltadas para o audiovisual no Brasil, a fim de analisar a formação das políticas de acesso atualmente em vigor. A partir da análise do programa Cinema Perto de Você, pretendemos verificar como se realiza na sua concepção e implementação a tensão entre os atores econômicos, políticos e sociais envolvidos e em que medida o programa contribui para a superação das desigualdades da vivência cultural da população e para a ampliação do acesso ao cinema.

A escolha do CPV como objeto de estudo, uma vez que está inserido no contexto do setor comercial de exibição e é implementado por meio de empresas privadas que pleiteiam os incentivos, aponta para uma análise privilegiada dos processos de mercantilização e espacialização, já que a concorrência com empresas exibidoras multinacionais e a perspectiva do lucro se apresentam como fatores preponderantes. Por outro lado, a opção de valorizar o contato com o público beneficiado e não restringir a coleta de dados a documentos oficiais e a entrevistas de gestores, empresários ou realizadores abre caminho para a observação do processo e da prática social sob uma perspectiva mais ampla, como sugere Mosco na proposta de transcender os limites das análises das instituições empresariais e governamentais e incorporar outros atores sociais.

\subsection{Os conceitos de política pública de cultura e Estado}

Para analisar o Cinema Perto de Você, que se insere em um contexto mais amplo das políticas públicas do cinema, é preciso esclarecer o que entendemos por política pública e por política de cultura neste trabalho. Além disso, para operar com os conceitos 
que levantamos a seguir, torna-se necessário apontar também qual o conceito de Estado que adotamos para que seja possível aplicar essas noções em nossa análise.

Segundo Enrique Saravia (2006), até a segunda metade do século XIX, predominou uma perspectiva jurídica na análise das realidades estatais. Uma visão administrativa ou organizacional só iria aparecer no começo do século XX, inicialmente nos Estados Unidos. Apesar da sua expansão para outros espaços, o modelo jurídico e as teorias clássicas de organização estatal ainda se perpetuaram nos países latinos, em que prevaleceu o legalismo: "Essa visão leva a uma consideração um tanto estática do Estado e da administração pública, que privilegia o estudo das estruturas e das normas que organizam a atividade estatal, deixando de lado as realidades vitais que permeiam as estruturas públicas" (SARAVIA, 2006, p.22).

Com a globalização, torna-se imperativa uma permanente adequação das estruturas organizacionais a um contexto condicionado por variáveis em constante mutação. Os sistemas de planejamento governamental desenvolvimentistas que foram bem-sucedidos nas décadas de 1950 e 1960 deixam de ser capazes de responder às demandas da população, que passa a reivindicar mais participação nas decisões estatais, na sua implementação, no seu controle e nos seus benefícios. "Tudo isso levou, ao longo dos anos 80, ao fortalecimento progressivo da concepção mais ágil da atividade governamental: a ação baseada no planejamento deslocou-se para a ideia de política pública" (SARAVIA, 2006, p.26). Sem desprezar a análise estrutural do Estado e da administração, aos poucos se incorpora uma visão dinâmica do funcionamento estatal que identifica as características das agências públicas que formulam as políticas, dos atores que participam desse processo, das variáveis externas e das relações de todos eles entre si.

Dessa forma, o autor conceitua política pública como "um fluxo de decisões públicas, orientado a manter o equilíbrio social ou a introduzir desequilíbrios destinados a modificar essa realidade" (SARAVIA, 2006, p.28). Ou, sob uma perspectiva mais operacional, as políticas públicas seriam:

um sistema de decisões públicas que visa a ações ou omissões, preventivas ou corretivas, destinadas a manter ou modificar a realidade de um ou vários setores da vida social, por meio da definição de objetivos e estratégias de atuação e da alocação dos recursos necessários para atingir os objetivos estabelecidos. (SARAVIA, 2006, p.29) 
Maria das Graças Rua (2009), antes de definir o que entende por política pública, ressalta que a sociedade é um conjunto de indivíduos com interesses e recursos de poder diferenciados, o que implica múltiplas possibilidades de cooperação, competição e conflito. A administração do conflito, por sua vez, pode ser realizada por meio da coerção ou da política. Para a autora, "a política consiste no conjunto de procedimentos formais e informais que expressam relações de poder e que se destinam à resolução pacífica dos conflitos quanto a bens públicos" (RUA, 2009, p.17). Essa definição corresponde ao termo anglo-saxão politics, enquanto política pública - correspondente a policy - refere-se à "formulação de propostas, tomada de decisões e sua implementação por organizações públicas, tendo como foco temas que afetam a coletividade, mobilizando interesses e conflitos" (RUA, 2009, p.19). A política pública (policy), portanto, é resultado da atividade política (politics).

Entre os vários modelos de análise de políticas públicas existentes, Rua advoga pelo modelo sistêmico, que entende o sistema político como um conjunto de estruturas e processos que se relacionam e produzem valores para a sociedade, transformando demandas em decisões imperativas. Na tentativa de superar algumas limitações desse modelo, que tende à redução lógica dos processos e a enfatizar as tomadas de decisão dentro do sistema político, relegando as demandas e apoios externos a um segundo plano, a autora propõe que uma forma de adotar o modelo sistêmico, sem descartar a complexidades dos processos, é associá-lo ao modelo do ciclo de políticas, que aborda as políticas públicas pela divisão em etapas sequenciais. Rua ressalta que as etapas não constituem um processo linear e podem se apresentar parcialmente superpostas, e que atividades de etapas distintas podem ocorrer simultaneamente. A partir do Quadro 2, é possível perceber que as etapas elencadas por Rua assemelham-se às etapas colocadas por Saravia, tanto em termos de quantidade e unidade dos processos, quanto na sistematização da ordem em que eles ocorrem.

Tanto Rua quanto Saravia ressaltam a participação dos atores políticos em todo o processo, entendidos como indivíduos, grupos ou organizações, públicos ou privados, com recursos de poder diferenciados, cujos interesses podem ser afetados, positiva ou negativamente, pela política implementada:

A elaboração de políticas pode ser vista como atividade politica incontornável, em que as percepções e os interesses dos atores individuais entram em todos os 
estágios. Nesse caso, a implementação transforma-se em atividade problemática e não em algo que deva ser dado como óbvio, como no modelo racional: a política é vista como barganha, o meio ambiente como conflitivo e o processo mesmo é caracterizado pela diversidade e pelas suas limitações. (SARAVIA, 2006, p.33, grifo do autor)

\section{Quadro 2 - Etapas das Políticas Públicas}

\begin{tabular}{|c|c|c|}
\hline & Enrique Saravia & Maria das Graças Rua \\
\hline Agenda & $\begin{array}{l}\text { Inclusão de determinado pleito na } \\
\text { agenda do poder público. O conjunto de } \\
\text { processos que conduzem os fatos sociais } \\
\text { a adquirir status de problema público, } \\
\text { transformando-os em objeto de debates } \\
\text { e controvérsias políticas. }\end{array}$ & $\begin{array}{l}\text { A formação da agenda ocorre } \\
\text { quando uma situação é } \\
\text { reconhecida como um problema } \\
\text { político e grupos de autoridade } \\
\text { dentro e fora do governo passam } \\
\text { a discuti-lo. }\end{array}$ \\
\hline $\begin{array}{l}\text { Elaboração } \\
\text { ou } \\
\text { Formação das } \\
\text { Alternativas }\end{array}$ & $\begin{array}{l}\text { Identificação e delimitação de um } \\
\text { problema atual ou potencial, } \\
\text { determinação das alternativas para sua } \\
\text { solução ou satisfação, avaliação de } \\
\text { custos e efeitos de cada uma delas e o } \\
\text { estabelecimento de prioridades. }\end{array}$ & $\begin{array}{l}\text { Após a inclusão na agenda, os } \\
\text { atores envolvidos começam a } \\
\text { apresentar propostas para sua } \\
\text { resolução, representando } \\
\text { interesses diversos. }\end{array}$ \\
\hline $\begin{array}{l}\text { Formulação } \\
\text { ou } \\
\text { Tomada de } \\
\text { Decisão }\end{array}$ & $\begin{array}{l}\text { Seleção e especificação da alternativa } \\
\text { considerada mais conveniente, seguida } \\
\text { de declaração que explicita a decisão } \\
\text { adotada, definindo seus objetivos e seu } \\
\text { marco jurídico, administrativo e } \\
\text { financeiro. }\end{array}$ & $\begin{array}{l}\text { Definição do núcleo central da } \\
\text { política que está sendo } \\
\text { formulada, a partir da } \\
\text { combinação possível entre as } \\
\text { alternativas apresentadas, } \\
\text { tentando alcançar uma solução } \\
\text { aceitável para o maior número } \\
\text { de partes envolvidas. }\end{array}$ \\
\hline Implementação & $\begin{array}{l}\text { Planejamento e organização do aparelho } \\
\text { administrativo e dos recursos } \\
\text { necessários para executar a política. } \\
\text { Elaboração dos planos e programas que } \\
\text { permitirão executá-la. }\end{array}$ & $\begin{array}{l}\text { Conjunto de decisões a respeito } \\
\text { da operação das rotinas } \\
\text { executivas das organizações } \\
\text { envolvidas na política. }\end{array}$ \\
\hline Execução & $\begin{array}{l}\text { Realização do conjunto de ações } \\
\text { destinado a atingir os objetivos } \\
\text { estabelecidos pela política. }\end{array}$ & $\begin{array}{l}\text { * Rua não separa a execução da } \\
\text { implementação. }\end{array}$ \\
\hline $\begin{array}{l}\text { Acompanhamento } \\
\text { ou Monitoramento }\end{array}$ & $\begin{array}{l}\text { Processo sistemático de supervisão da } \\
\text { execução de uma atividade, com o } \\
\text { objetivo de fornecer a informação } \\
\text { necessária para eventuais correções, a } \\
\text { fim de assegurar a consecução dos } \\
\text { objetivos estabelecidos. }\end{array}$ & $\begin{array}{l}\text { Procedimentos de apreciação } \\
\text { dos processos adotados, dos } \\
\text { resultados preliminares e } \\
\text { intermediários obtidos e do } \\
\text { comportamento do ambiente da } \\
\text { política. }\end{array}$ \\
\hline Avaliação & $\begin{array}{l}\text { Mensuração e análise, a posteriori, dos } \\
\text { efeitos produzidos na sociedade pelas } \\
\text { políticas públicas, especialmente no que } \\
\text { diz respeito às realizações obtidas e às } \\
\text { consequências previstas e não previstas. }\end{array}$ & $\begin{array}{l}\text { Procedimentos de julgamento } \\
\text { dos resultados de uma política, } \\
\text { segundo critérios que expressam } \\
\text { valores, visando subsidiar } \\
\text { decisões quanto aos ajustes } \\
\text { necessários para que os } \\
\text { resultados esperados sejam } \\
\text { obtidos. }\end{array}$ \\
\hline
\end{tabular}

Fonte: SARAVIA, 2006, p.31-34; RUA, 2009, p.36-38. 
É importante destacar, ainda, conforme apontam Rua (2009) e Castro (2008), que o caráter público de uma política não se define por sua abrangência ou pelo interesse público de suas iniciativas. Uma política só é pública quando o Estado "é determinante seja na formulação direta delas, seja na definição do marco regulatório da sua implementação" (CASTRO, 2008, p.66). Ou seja, é o caráter jurídico imperativo do Estado na formulação e na implementação da política, com a autoridade soberana do poder público, que a torna uma política pública.

As definições de política pública de cultura, ou política cultural, partem basicamente dos mesmos pressupostos apresentados acerca das políticas públicas em geral, porém assumem reflexões específicas que são essenciais no âmbito deste trabalho. Como apontam Rubim (2007) e Barbalho (2008), apesar da vasta quantidade de estudos de análise de políticas culturais em vários momentos históricos e localidades, ou mesmo sobre financiamento da cultura, poucas são as contribuições teóricas e conceituais sobre sua definição: "Faz-se necessário, portanto, elaborar uma definição afinada com a prática e com a pesquisa no que diz respeito às políticas de cultura em curso nos dias de hoje" (BARBALHO, 2008, p.20).

A definição de Simis parece resumir a contento essa discussão:

Entendo a política cultural como parte das políticas públicas. É verdade que a expressão política pública possui diversas conotações, mas aqui genericamente significa que se trata da escolha de diretrizes gerais, que têm uma ação, e estão direcionadas para o futuro, cuja responsabilidade é predominantemente de órgãos governamentais, os quais agem almejando o alcance do interesse público pelos melhores meios possíveis, que no nosso campo é a difusão e o acesso à cultura pelo cidadão. (SIMIS, 2007, p.133)

Barbalho aponta que, no esforço de definir e elaborar as políticas de cultura, é impossível não ressaltar a posição estratégica que as indústrias culturais ocupam, embora as várias esferas governamentais tenham sistematicamente agido de forma periférica nessa área: "Este desafio se coloca quando se compreende que a cultura como um todo está cada vez mais pautada por esta sua área específica, a dos fenômenos midiáticos e das indústrias culturais" (BARBALHO, 2008, p.23).

Para o autor, a mediação simbólica e a constituição de imaginários, ou mesmo a formação intelectual e subjetiva dos cidadãos, dá-se em grande parte por meio dos canais midiáticos. Não perceber a importância formativa e informativa das indústrias culturais é um erro estratégico na formulação das políticas culturais. Na falta de uma política estatal 
bem delineada, há uma tendência de transferir para o mercado uma parcela crescente da responsabilidade sobre a política cultural do país, que passa a ser tratada prioritariamente do ponto de vista do lucro. O Estado, ao abdicar da determinação de onde investir recursos, e sem um planejamento de longo prazo, deixa de garantir a cultura como um direito fundamental, em suas dimensões de acesso e de livre manifestação.

\begin{abstract}
É preciso ter em conta que a Cultura é um direito e, nesse sentido, é muito mais que uma atividade econômica, embora a economia da cultura tenha hoje um papel importante na geração de empregos. Os direitos sociais são aqueles que dizem respeito a um mínimo de bem-estar econômico, de participação, de ser e viver na plenitude a civilização [...]. Para concretizá-los é preciso admitir um grau maior de intervenção do Estado na vida dos cidadãos por meio dos mais variados mecanismos e instituições que assegurem sua implantação e observância. (SIMIS, 2007, p.134)
\end{abstract}

Simis salienta que não é papel do Estado produzir cultura, ou mesmo dirigi-la e conduzi-la, mas sim formular políticas que fomentem os meios de produção, acesso e divulgação, pois todo cidadão deve poder expressar a sua visão de mundo. Segundo a autora, o paradigma da nacionalidade já foi superado e não se trata mais de construir uma nação, mas sim de democratizar uma sociedade injusta e desigual. Na mesma linha, Albuquerque Jr. (2007) afirma que vivemos em um mundo de múltiplas manifestações e expressões culturais e que "é preciso superar as políticas culturais apoiadas no discurso da identidade, seja nacional, seja regional ou local, quase sempre excludentes, pois manipuladoras de mitos a serviço da manutenção de um imaginário favorável aos grupos que controlam o Estado" (ALMEIDA JR., 2007, p.75).

Formular e implementar políticas, inclusive de cultura, pressupõe um ambiente de intenso conflito, constituído pela disputa de atores que historicamente apresentam forte desigualdade de recursos de poder frente a instâncias estatais: "A problemática que se coloca aqui é a da ampliação do nível de participação do conjunto da sociedade nos diversos níveis de gestão e de produção da cultura e nos canais de circulação dessa produção" (CALABRE, 2007, p.105). Ampliar o acesso à cultura ou garanti-la como direito não é promover artistas e produtores culturais que "produzem cultura" para que o povo a consuma, mas criar condições para que as pessoas tornem-se capazes de participar da vida pública de forma consciente e ativa: “A equidade na cultura é garantida tanto na criação de condições adequadas de circulação dos bens culturais, como de criar 
possibilidades para que todas as pessoas possam participar e fruir dessas condições" (PORTO, 2007, p.177).

Diante do exposto, e de acordo com a proposição de Albuquerque Jr. (2007, p.62), para debater a relação entre Estado e cultura é preciso definir o que se entende por ambos. No amplo leque de conceituações sobre o Estado, a perspectiva que se alinha ao nosso referencial teórico-metodológico $\mathrm{e}$ às formulações em torno dos processos de mercantilização, espacialização e estruturação apontados, bem como às reflexões levantadas sobre políticas públicas de cultura, é o conceito de Estado ampliado proposto por Antonio Gramsci.

Figura central do partido comunista italiano na primeira metade do século XX, Gramsci formulou, a partir do legado de Marx e Lenin, uma teoria da ação política que tem ampla ressonância ainda hoje. Para Martin Carnoy (1988), Gramsci vai além de Marx, Engels, Lenin e Trotski com a sua elaboração sobre a sociedade civil e a elevação da hegemonia burguesa a um lugar de destaque na ciência política: "Ao fazê-lo, ele enfatizou de forma muito mais aguda que os teóricos precedentes o papel da superestrutura na perpetuação das classes e na prevenção do desenvolvimento da consciência de classe" (CARNOY, 1988, p.90), o que confere ao Estado parte da função de promover a hegemonia burguesa.

Carnoy aponta que, para Marx, a sociedade civil é estrutura, ou seja, relações de produção. Já para Gramsci, de acordo com o autor, ela seria superestrutura, "que representa o fator ativo e positivo no desenvolvimento histórico; é o complexo das relações ideológicas e culturais, a vida espiritual e intelectual, e a expressão política dessas relações torna-se o centro da análise, e não a estrutura" (CARNOY, 1988, p.90). Gramsci não nega, entretanto, que a superestrutura está intimamente ligada às relações de produção, "pois, embora a hegemonia seja ético-política, ela também deve ser econômica, deve necessariamente ser baseada na função decisiva da atividade econômica" (GRAMSCI apud CARNOY, 1988, p.102).

A novidade do conceito de sociedade civil em Gramsci, para Coutinho (2012, p.127), é que ela assume o caráter de portadora material da figura social da hegemonia, como esfera de mediação entre a infraestrutura econômica e o Estado. Segundo o autor, o conceito de Estado ampliado de Gramsci consiste na incorporação, no âmbito do Estado, tradicionalmente entendido como uma sociedade política (aparelhos e burocracias estatais), 
de um equilíbrio dinâmico entre a sociedade política e a sociedade civil, esta última formada pelo conjunto de organismos de participação política voluntários (e, por isso, privados), relativamente autônomos em relação à sociedade política, que elaboram e difundem ideologias. Cada uma, entretanto, opera dialeticamente de maneira distinta. Enquanto a sociedade política busca exercer sua hegemonia pela coerção, a hegemonia na sociedade civil ocorre por meio da direção política e do alcance do consenso.

Para Gramsci, as duas formas de obter hegemonia operam em favor das classes dominantes e, para que seja possível a construção de uma contra-hegemonia, a luta pela consciência política coletiva torna-se uma etapa essencial. Impedir que os indivíduos adquiram condições de alcançar essa tomada de consciência é uma maneira de manter o status quo e de deixá-los à parte dos processos de decisão política.

A maneira como aqui entendemos as políticas públicas de cultura, portanto, revela como a sociedade civil é ativa em seu processo de formulação e implementação, ao mesmo tempo em que aponta para a hegemonia de uma concepção de cultura baseada na mercadoria e no consumo, a qual correntes contra-hegemônicas tentam combater, por meio da defesa de um conceito de cultura baseado em direito, diversidade e autonomia. Entender que uma política de cultura deve promover a ampliação do conhecimento e da participação ativa de todos na produção e fruição das manifestações culturais é defender uma posição contra-hegemônica em um contexto no qual as forças econômicas e políticas dominantes utilizam-se dos aparelhos públicos e privados para se manter.

\section{3. $O$ conceito de acesso à Cultura}

O foco de análise das políticas de cultura neste trabalho é o acesso ao cinema e às obras cinematográficas produzidas no país. Dessa forma, após entender qual a perspectiva teórica que adotamos, a Economia Política da Comunicação, e delimitar qual a concepção de Estado e de política pública de cultura que irá guiar nossa análise, faz-se necessário esclarecer o conceito de acesso com que vamos trabalhar.

Embora o termo acesso seja uma constante nos documentos oficiais e na literatura acadêmica que trata de políticas públicas, poucas são as abordagens que se preocupam em definir qual o seu conceito no âmbito da cultura. Na revisão bibliográfica dos estudos sobre 
políticas públicas do audiovisual, a palavra acesso é recorrente, porém com distintas acepções. Na maior parte das ocorrências, está relacionada à internet e à massificação das novas tecnologias e plataformas digitais, ou mesmo quando se refere à disponibilidade de determinado meio de comunicação, como a televisão aberta, presente em 96,8\% dos domicílios brasileiros (dados do IBGE em 2010). É frequente, também, a utilização do termo para tratar da dificuldade de alcance do conteúdo nacional independente nas diversas janelas de exibição, assim como na abordagem das disparidades relativas ao acesso a recursos estatais de fomento ao audiovisual. A noção de ampliação do acesso à cultura é unânime na discussão das finalidades e objetivos das políticas culturais, frequentemente associada a uma melhor distribuição geográfica da oferta cultural, ou de acesso relacionado a transporte e preços de ingresso.

A perspectiva que relaciona o acesso à cultura com a ideia de consumo de bens culturais, implícita na formulação de diversas políticas, é perceptível, por exemplo, na Coleção Cadernos de Políticas Culturais, elaborada em parceria pelo Ministério da Cultura (MinC) e pelo Instituto de Pesquisa Econômica Aplicada (Ipea), com o objetivo de fornecer subsídios para a (re)formulação de políticas públicas de cultura no país. Especialmente no terceiro volume - Economia e política cultural: acesso, emprego e financiamento (2007) - é possível perceber que o acesso é definido e mensurado a partir de variantes como o percentual da renda familiar dispendida com bens culturais (livros, periódicos, discos, teatro, shows, cinema, televisão, informática, lazer etc), de acordo com a faixa de renda, escolaridade, idade, sexo e raça, e a partir da disponibilidade de equipamentos culturais distribuídos pelos municípios e regiões metropolitanas do país. A realização do direito de acesso à cultura se materializaria, de certa forma, no poder de consumo:

\footnotetext{
Portanto, além de o consumo possuir uma dimensão cultural geral, o consumo de bens culturais também diz algo sobre a organização social e sobre como a mesma cria condições para o exercício da cidadania, a formação da opinião e a participação nos processos políticos e sociais. (BRASIL, 2007, p.19)
}

Embora o relatório reconheça que a pesquisas de orçamento familiar impõem uma limitação metodológica, pois os dispêndios com bens culturais não podem ser considerados um indicador direto de preferência e das estratégias de ordenação de significados, além de não levar em consideração a prática cultural que não é realizada dentro do mercado, a 
importância que ele confere a esses parâmetros de consumo e de oferta de equipamentos culturais corrobora com a noção de acesso atrelada primordialmente à dimensão material. Curiosa, neste caso, é a constatação de que famílias de mais alta renda, domiciliadas em municípios de ampla oferta, dispendem praticamente a mesma porcentagem da renda em bens culturais que família de renda média e baixa, apontando que poder aquisitivo e disponibilidade de equipamentos não são as únicas ou as principais variáveis para a ampliação do acesso.

A mesma visão transparece no programa de fomento à universalização do acesso às obras audiovisuais cinematográficas brasileiras de longa-metragem, estabelecido pela Instrução Normativa $\mathrm{n}^{\circ} 77$, de outubro de 2008. O programa aponta como objetivo a promoção dos direitos culturais e acesso às fontes da cultura brasileira por meio da inclusão social no segmento de mercado de salas de exibição, bem como o estímulo à participação dos filmes brasileiros no mercado interno, porém, sua única ação concreta é conceder apoio financeiro para o barateamento dos ingressos das sessões de filmes nacionais. Ikeda (2011, p.72) aponta, contudo, que "a ação se resumiu a uma única semana e a Ancine não divulgou os números consolidados sobre o aumento do número de ingressos vendidos em consequência a este estímulo".

Marta Porto (2007) afirma que, desde a década de 1970, com as propostas políticas de Aloísio Magalhães, a noção de democratização do acesso tornou-se bastante presente nos documentos de cultura no Brasil. Para a autora, até meados da década de 1990, a melhora do acesso está diretamente relacionada à ampliação dos espaços e circuitos de cultura, o que reforça a ideia de que existem produtores de cultura, de um lado, e um público amplo "receptor" desta cultura, de outro.

\footnotetext{
Aos poucos a noção difusionista da cultura, como meio de melhorar o acesso da população à produção artístico-cultural vai sendo superada pela noção de diálogo e intercâmbio culturais. O que pressupõe que todos os atores sociais são capazes de produzir cultura e estão em condições de igualdade para trocar e experimentar novas práticas e experiências. Assim a ideia de acesso passa a ser muito mais um desafio de estabelecer vias de diálogo, de encontro entre diferentes, num contexto de diversidades, do que produzir linhas programáticas baseadas na noção de entreter ou de levar a cultura ao povo. (PORTO, 2007, p.168)
}

Por esta perspectiva, o conceito de acesso se distancia da noção de oferta e se torna mais complexo à medida que pressupõe igualdade de condições de participar da vida pública, de disputar recursos, de conceber a cultura como parte essencial do exercício da 
cidadania. Como já apontavam Bourdieu e Darbel (2007, p.69) no fim da década de 1960, embora os museus, por exemplo, sejam espaços totalmente acessíveis, pois não há maiores obstáculos econômicos que impeçam a frequência, somente uma pequena parcela da sociedade costuma visitá-los. Os autores ressaltam que a concretização do acesso depende de uma igualdade de "necessidades culturais", ou seja, de condições de educação, formação e experiência que gerem a expectativa e a satisfação de exercer a prática cultural. Ou, como resume Porto (2007, p.169), “o acesso à cultura, ou a necessidade de apropriarse continuamente de suas variáveis e disponibilizar esse acervo à comunidade, é um ato consciente que exige inserção coletiva e política de todos os cidadãos." As políticas culturais, portanto, se almejam ampliar o acesso, têm o desafio de trabalhar também nas origens da desigualdade das necessidades culturais.

Para Porto, a experiência cultural ocorre a partir do diálogo constante entre práticas criativas próprias e o livre acesso aos acervos culturais tradicionais e contemporâneos. Nesse sentido:

\footnotetext{
Duas dimensões políticas ganham relevância no estímulo ao cumprimento desse objetivo: a universalização dos bens e serviços culturais ofertados a toda a população, através de equipamentos, programas e serviços públicos permanentes de cultura que incentivem a formação de hábitos de fruição cultural e promovam a visibilidade e a troca de produções culturais e artísticas locais e comunitárias, e a luta por uma educação de qualidade, pensada como via fundamental de crescimento pessoal e coletivo, promotora de autonomia, independência e identidade. (PORTO, 2007, p.170)
}

Embora não trate exatamente do conceito de acesso, a proposta de transição entre democratização cultural e democracia cultural, trazida por Isaura Botelho (2007), também é uma contribuição relevante. Trata-se do deslocamento do foco de debate das políticas culturais do universo quase exclusivo das artes para a concepção da cultura como direito e como cidadania. Para Botelho, tradicionalmente (e ainda de forma dominante), costuma-se tomar a cultura erudita como o paradigma que direciona a avaliação das desigualdades de acesso à cultura, sendo o alvo principal da maioria das políticas culturais formuladas pelos poderes públicos.

O pressuposto é de que existe um legado que tem valor universal e, sem maiores discussões, deveria ser assimilado como repertório de qualquer pessoa "culta", em oposição às práticas consideradas 'locais', vistas como expressões de saberes particulares, em princípio mais limitados do que os herdados da alta Cultura. Nesta linha, a democratização é entendida como um movimento de cima para baixo capaz de disseminar, a um número cada vez maior de indivíduos, essa 
herança feita de práticas e representações que, pela sua universalidade, compõem um valor maior em nome do qual se formulam as políticas públicas na área da cultura. (BOTELHO, 2007, p.172)

Segundo Botelho, a perspectiva da democratização da cultura se baseia em duas noções equivocadas: (1) define que a cultura socialmente legitimada é aquela que deve ser difundida; (2) supõe que basta colocar a obra e o público em contato para que este seja conquistado. Assim, as políticas de democratização conferem maior importância aos obstáculos materiais que se impõem às práticas culturais, como a má distribuição ou a ausência de espaços culturais ou os preços elevados dos ingressos. A autora alinha-se à visão de Porto (2007), Bourdieu e Darbel (2007), ao afirmar que a dimensão do acesso não se reduz aos fatores econômicos ou de oferta. Pelo contrário, está relacionada a distinções de formação e de hábitos cotidianos que têm grande incidência sobre as práticas culturais. Ressalta, inclusive, que a própria posição de legitimidade adquirida pela cultura erudita é uma construção histórica e que há outras formas de produção e outras tradições populares de cultura, embora todas elas estejam de alguma forma marcadas pela mercantilização na sociedade capitalista contemporânea.

Botelho defende que, para superar o paradigma da cultura erudita e estabelecer uma política pública articulada que contemple as várias dimensões da vida cultural, sem preconceitos elitistas ou populistas, é preciso avançar na reflexão sobre o perfil das práticas culturais da população, levando em consideração a dinâmica de pluralidade, no âmbito da produção, e de igualdade, no plano do controle da distribuição e dos circuitos de consumo: "Isto implica colocar todos os meios à disposição, combater a dificuldade ou impossibilidade de acesso à produção menos 'vendável', e também contrabalançar o excesso de oferta da produção que segue as leis do mercado" (BOTELHO, 2007, p.173). A noção de democracia cultural proposta por Botelho pressupõe a existência de públicos diversos, bem como a inexistência de um paradigma único para a legitimação das práticas culturais, além de buscar ultrapassar variáveis como renda, faixa etária e localização domiciliar como as únicas determinantes do nível de consumo de natureza cultural.

Na mesma linha, Rubim afirma que:

Uma política cultural rigorosamente instituída não pode deixar de interferir, propondo formulações e ações sobre o tema da fruição, do consumo e dos públicos culturais. Nesta perspectiva, todos os indivíduos estão imersos em ambientes culturais ainda que em modalidades muito desiguais de acesso pleno aos seus estoques e fluxos. Mesmo a fruição e o consumo, talvez a esfera mais 
larga de participação, pode ser obstruído por requisitos econômicos, sociais e educacionais que limitam tal acesso. (RUBIM, 2007, p.156)

A área da saúde, que apresenta certa tradição na discussão do conceito de acesso aos serviços, também pode trazer contribuições para esta elaboração, apesar de suas especificidades. Cláudia Travassos e Mônica Martins (2004) realizaram uma revisão bibliográfica do conceito de acesso e acessibilidade nos estudos sobre utilização dos serviços de saúde e apontam que, apesar das nuances conceituais, o termo acessibilidade tende a se referir a características da oferta, enquanto acesso, na visão de Starfield (apud TRAVASSOS; MARTINS, 2004, p.195), por exemplo, leva em conta a forma como as pessoas percebem a disponibilidade de serviços, o que influencia na decisão de procurálos.

Já para Andersen (apud TRAVASSOS; MARTINS, 2004, p.192), a noção de acesso possui duas dimensões: uma potencial e uma realizada. Acesso potencial caracteriza-se pela existência de fatores que propiciem o uso de serviços, enquanto acesso realizado representa a utilização de fato desses serviços, o que depende de fatores que vão além da oferta.

\footnotetext{
Neste modelo, estabelece-se uma hierarquia na qual fatores contextuais, que são aqueles relacionados às políticas de saúde e à oferta de serviços, intervêm no uso de forma direta e indireta, por intermédio dos fatores individuais. Importante destacar, para fins de formulação de políticas, que elementos próprios do sistema de saúde (oferta) são passíveis de mudança mediante intervenção governamental ou institucional, enquanto apenas algumas das características dos indivíduos são passíveis de mudança por essas ações. (ANDERSEN apud TRAVASSOS; MARTINS, 2004, p.192)
}

Landini, Cowes e D'amore (2014, p.232) propõem uma discussão crítica da noção de acessibilidade, entendida como a articulação ou ajuste entre as características da oferta e as características e necessidades da demanda. Para os autores, é comum perceber as barreiras prioritariamente pelos seus aspectos geográficos e financeiros, porém, eles ressaltam que a dimensão cultural é igualmente relevante. À dimensão cultural, Stolkiner e sua equipe (apud LANDINI; COWES; D’AMORE, 2014, p.234) adicionam uma dimensão simbólica, destacando que os imaginários sociais e as representações dos sujeitos também podem se constituir em barreiras específicas que devem ser levadas em conta.

Neste trabalho, seguindo a contribuição dos autores citados, traremos o acesso para o centro da análise e o entenderemos como uma dimensão complexa da implementação das 
políticas públicas de cinema, que envolve não apenas o aspecto material (oferta de espaços de exibição, distribuição geográfica das salas, localização das salas nos municípios, valor dos ingressos), mas principalmente o aspecto cultural (individual e coletivo), que faz com que as pessoas possam se identificar com o cinema nacional e se sentir motivadas a assistir aos filmes.

\subsection{Procedimentos metodológicos}

Para alcançar o objetivo da pesquisa, ou seja, investigar como tem sido formulada e implementada no Brasil uma política de acesso ao cinema, foi preciso delimitar um objeto de estudo que fosse representativo desse conjunto de diretrizes e ações que constituem a política de cinema no Brasil. Pelas razões já colocadas, o Cinema Perto de Você pareceu oferecer as melhores condições de investigação e o estudo de caso mostrou-se o procedimento mais adequado para a nossa abordagem. Gil $(2008$, p.57) define o método como "o estudo profundo e exaustivo de um ou de poucos objetos, de maneira a permitir o seu conhecimento amplo e detalhado" e aponta que esse procedimento é utilizado nas Ciências Sociais pela possibilidade de: (a) explorar situações da vida real cujos limites não estão claramente definidos; (b) descrever a situação do contexto em que ocorre determinada situação; e (c) explicar as variáveis causais de determinado fenômeno em situações muito complexas que não possibilitam a utilização de levantamentos e experimentos (GIL, 2008, p.58). Nos enquadramos, portanto, no terceiro caso.

Gil também chama a atenção para duas pertinentes ressalvas que são feitas ao método: a falta de rigor metodológico, que obriga o pesquisador a redobrar cuidados no planejamento e na coleta e análise de dados, e a dificuldade de generalização. Os estudos de caso, segundo o autor, não têm o objetivo de proporcionar o conhecimento preciso das características de uma população a partir de procedimentos estatísticos, mas sim o de expandir ou generalizar proposições teóricas. Neste sentido, optamos por empreender uma análise que parte de conceitos-chave para tentar interpretar dados e relações em sua complexidade, em vez de fazer uma avaliação categórica do Cinema Perto de Você, a partir de indicadores e variáveis mensuráveis, o que seria uma abordagem válida, porém limitada pela dificuldade de estabelecer, de antemão, esses indicadores. 
Mais especificamente, adotamos a técnica da análise documental da Lei 12.599/2012, do site do programa, dos relatórios e das bases de dados disponibilizados pela Ancine e do perfil de programação de três salas contempladas pelo CPV. Para a análise da programação, delimitamos o período de um ano, de julho de 2013 a junho de 2014 e, na tentativa de abarcar a maior variedade possível, foram escolhidas salas administradas por três empresas diferentes, nas três regiões do país que possuíam novas salas contempladas durante o período: Cinesystem Imperatriz (MA), Praia de Belas Porto Alegre (RS) e Cinespaço Granja Viana (SP).

A pesquisa de campo baseou-se em uma observação não participante, realizada em três cidades que possuem salas do $\mathrm{CPV}$, e na realização de entrevistas, de tipo semiestruturadas, que foram realizadas com representantes dos quatro grupos de atores diretamente envolvidos com o programa: um formulador e/ou coordenador, um gerente de uma empresa exibidora contemplada pelo recurso, os administradores locais das salas e o público. O representante da Ancine entrevistado foi Selmo Kaufmann, ex-coordenador da Unidade Gestora do Cinema Perto de Você e atual coordenador de Infraestrutura e Projetos Especiais da Superintendência de Desenvolvimento Econômico da Ancine, à qual o programa encontra-se subordinado. As quatro empresas contempladas com recursos de crédito e investimento para a construção de novas salas foram contatadas, porém só a Rede Cinesystem, representada pela gerente de expansão Jane Gambarin, retornou nossos contatos em tempo hábil. A primeira entrevista foi realizada presencialmente na sede da Ancine, no Rio de Janeiro, e a segunda, via troca de e-mails. Quanto ao público, foram entrevistados 30 espectadores de cada sala, totalizando 90. Optamos pela entrevista com o público, no lugar da aplicação de questionário, por conta da possibilidade de obtenção de uma maior diversidade de respostas e pela flexibilidade do método, que permite o esclarecimento das perguntas e a adaptação às circunstâncias, além do contato interpessoal, que estimula respostas mais longas, específicas e completas. Por conta dessa opção, não foi possível realizar um número de entrevistas que tornasse o universo estatisticamente representativo - embora tenha havido o cuidado de equilibrar variantes como gênero e faixa etária dos entrevistados -, porém acreditamos que foi uma quantidade adequada aos nossos propósitos de investigação.

A observação não participante, apropriada para situações e espaços de caráter público, como é o caso dos cinemas, foi registrada por meio de notas e fotografias e levou 
em conta principalmente duas dimensões: (a) o perfil dos sujeitos que frequentavam o cinema e seu comportamento; (b) o espaço físico dos cinemas, dos shoppings e do entorno onde se encontram. A pesquisa de campo foi realizada no mês de abril de 2014, nas cidades de Hortolândia (SP), Rio de Janeiro (RJ) e Imperatriz (MA). A escolha dos locais levou em consideração os seguintes fatores:

1. Data de inauguração: foram levantadas as salas que tinham pelo menos 1 ano de funcionamento;

2. Variedade do perfil das cidades e da oferta de cinema: Hortolândia é um município de pequeno porte e o cinema visitado é o primeiro da cidade; Imperatriz é um centro regional da região tocantina e era a única cidade fora do eixo Sul-Sudeste com um complexo contemplado naquele momento; o Rio de Janeiro é uma das maiores cidades do país e possui a segunda maior oferta de cinemas, além do maior número de salas do CPV por município. A partir dessa variedade de características, pretendemos avaliar que diferenças de impacto a chegada das novas salas apresentou em cada perfil de cidade.

3. Receptividade da gerência das salas em relação à pesquisa. Como apontado, a Rede Cinesystem, que administra as três salas visitadas, foi a única que retornou nossos contatos em tempo hábil e atendeu a todas as nossas solicitações.

Para a obtenção das informações necessárias para responder às questões da pesquisa, elaboramos o seguinte roteiro de entrevistas e guia para a análise documental, sistematizado no Quadro 3. 


\section{Quadro 3 - Guia de entrevista e análise documental}

\begin{tabular}{|c|c|c|}
\hline & & Perguntas \\
\hline $\begin{array}{l}\text { O } \\
\text { : } \\
0 \\
0 \\
0 \\
0 \\
0\end{array}$ & $\begin{array}{l}\text { - Lei } 12.599 / 2012 \\
\text { - Site do programa } \\
\text { - Relatórios do } \\
\text { Observatório Brasileiro do } \\
\text { Cinema e do Audiovisual } \\
\text { (OCA) }\end{array}$ & $\begin{array}{l}\text { Quais os objetivos e metas do programa e como ele funciona? } \\
\text { Quantas salas foram contempladas e onde funcionam? } \\
\text { Qual o perfil dos locais onde foram instaladas as salas? } \\
\text { Qual a proporção de filmes brasileiros e estrangeiros na programação? } \\
\text { Quais os títulos brasileiros e quanto tempo ficaram em cartaz? } \\
\text { Qual a média de público dos filmes nacionais? } \\
\text { Qual a média de valor dos ingressos? }\end{array}$ \\
\hline \multirow{4}{*}{  } & $\begin{array}{l}\text { Selmo Kaufmann, } \\
\text { coordenador de } \\
\text { Infraestrutura e Projetos } \\
\text { Especiais da Ancine }\end{array}$ & $\begin{array}{l}\text { Como surgiu a ideia do programa? } \\
\text { Como se deu a formulação? } \\
\text { Atores externos à Ancine foram consultados? } \\
\text { Quais os objetivos e metas do programa? } \\
\text { Como você avalia a implementação? } \\
\text { Quais os acertos e dificuldades? } \\
\text { Que tipo de recursos foram acionados? } \\
\text { Você avalia que as metas estão sendo atingidas? } \\
\text { Nas salas contempladas, há algum tipo de incentivo adicional à presença } \\
\text { de filmes nacionais ou uma política de preços de ingressos? }\end{array}$ \\
\hline & $\begin{array}{l}\text { Jane Gambarin, gerente de } \\
\text { expansão da Rede } \\
\text { Cinesystem }\end{array}$ & $\begin{array}{l}\text { Como ficou sabendo da existência do programa? } \\
\text { Como foi o processo de obtenção do incentivo? Houve algum entrave? } \\
\text { Como se deu a escolha dos locais para implantação das salas? } \\
\text { Essas salas seriam implantadas nessas localidades mesmo sem a ajuda do } \\
\text { programa? } \\
\text { Você considera as médias de público e bilheteria satisfatórias nas salas? } \\
\text { Elas acompanham o desempenho das demais salas da rede? } \\
\text { Como é feita a escolha dos filmes da grade? }\end{array}$ \\
\hline & $\begin{array}{l}\text { Gerentes das salas } \\
\text { contempladas }\end{array}$ & $\begin{array}{l}\text { Como era a oferta de cinema aqui antes da criação da sala? } \\
\text { Qual o perfil do público que frequenta a sala? } \\
\text { Como você avalia o desempenho de bilheteria da sala? Qual a média de } \\
\text { público mensal/anual? } \\
\text { Como é feita a escolha dos filmes da grade? O público participa? } \\
\text { Que filmes apresentam melhores bilheterias? } \\
\text { Quais as estratégias de atração do público e como funcionam? }\end{array}$ \\
\hline & $\begin{array}{l}\text { Público das salas } \\
\text { contempladas }\end{array}$ & $\begin{array}{l}\text { Com que frequência vai ao cinema? } \\
\text { Com que frequência assiste a filmes em casa? } \\
\text { A existência desta sala interferiu na sua frequência? } \\
\text { A que tipo de filmes costuma assistir? } \\
\text { Que salas costumava frequentar antes da inauguração desta? } \\
\text { Qual a sua opinião sobre a estrutura da sala e sobre a programação? } \\
\text { Você costuma assistir a filmes nacionais? } \\
\text { O que você acha da oferta de filmes nacionais neste cinema? } \\
\text { Qual a sua opinião sobre o valor dos ingressos? Se fosse mais barato, } \\
\text { viria mais vezes? } \\
\text { Onde mora e como costuma vir ao cinema? } \\
\text { Como escolhe os filmes a que assiste? }\end{array}$ \\
\hline
\end{tabular}

Fonte: Elaboração própria. 


\subsection{Dados gerais da pesquisa de campo}

\subsubsection{Hortolândia}

Hortolândia é uma cidade da região metropolitana de Campinas, com população estimada em aproximadamente 209 mil habitantes. A região, inicialmente chamada de povoado de Jacuba, nos séculos XVIII e XIX era dominada pelo cultivo de café e algodão e só teve seu primeiro loteamento demarcado em 1947, quando passou a ser chamada de Parque Ortolândia. O distrito esteve subordinado ao município de Sumaré até 1991, quando foi desmembrado e se tornou um município autônomo. Atualmente, a principal atividade econômica de Hortolândia é o setor de serviços (62\% do PIB), seguido pela indústria (37,5\% do PIB). O valor do rendimento médio mensal per capita é de R\$550. ${ }^{2}$

Na transição entre Campinas e Hortolândia, é possível perceber o contraste entre as duas cidades. A periferia de Hortolândia apresenta vários casebres, muitos deles de madeira, e diversos focos de lixo amontoado. À medida que nos aproximamos do centro, vão aparecendo casas de médio porte, muitas com aquecedores solares e algumas visivelmente recém-reformadas e com carros populares nas pequenas garagens. A cidade não possui uma verticalização expressiva, mas já apresenta alguns conjuntos residenciais de prédios de médio porte, do programa Minha Casa Minha Vida, do governo federal. Nos trajetos por onde passei, os únicos equipamentos de lazer que pude observar foram algumas praças e alguns campinhos de futebol.

O complexo de salas de cinema da Rede Cinesystem, inaugurado em julho de 2012, está localizado no Shopping Hortolândia e é o primeiro e único cinema da cidade. São 5 salas, sendo 2 com projeção 3D, totalizando 1.486 lugares. O shopping fica no centro comercial da cidade, onde há comércio de médio porte e algumas lojas de atacado (roupas, móveis, eletroeletrônicos). O shopping é pequeno (Figura 1), com dois pavimentos e um supermercado grande (Walmart) no térreo. Possui cerca de 50 lojas, entre elas, lojas de departamento como C\&A, Lojas Americanas, Marisa e Pernambucanas. A praça de alimentação conta com cerca de 15 lanchonetes de franquias conhecidas: McDonald's, Griletto, Habibs, Bob's etc.

\footnotetext{
${ }^{2}$ Dados do IBGE em 2010.
} 


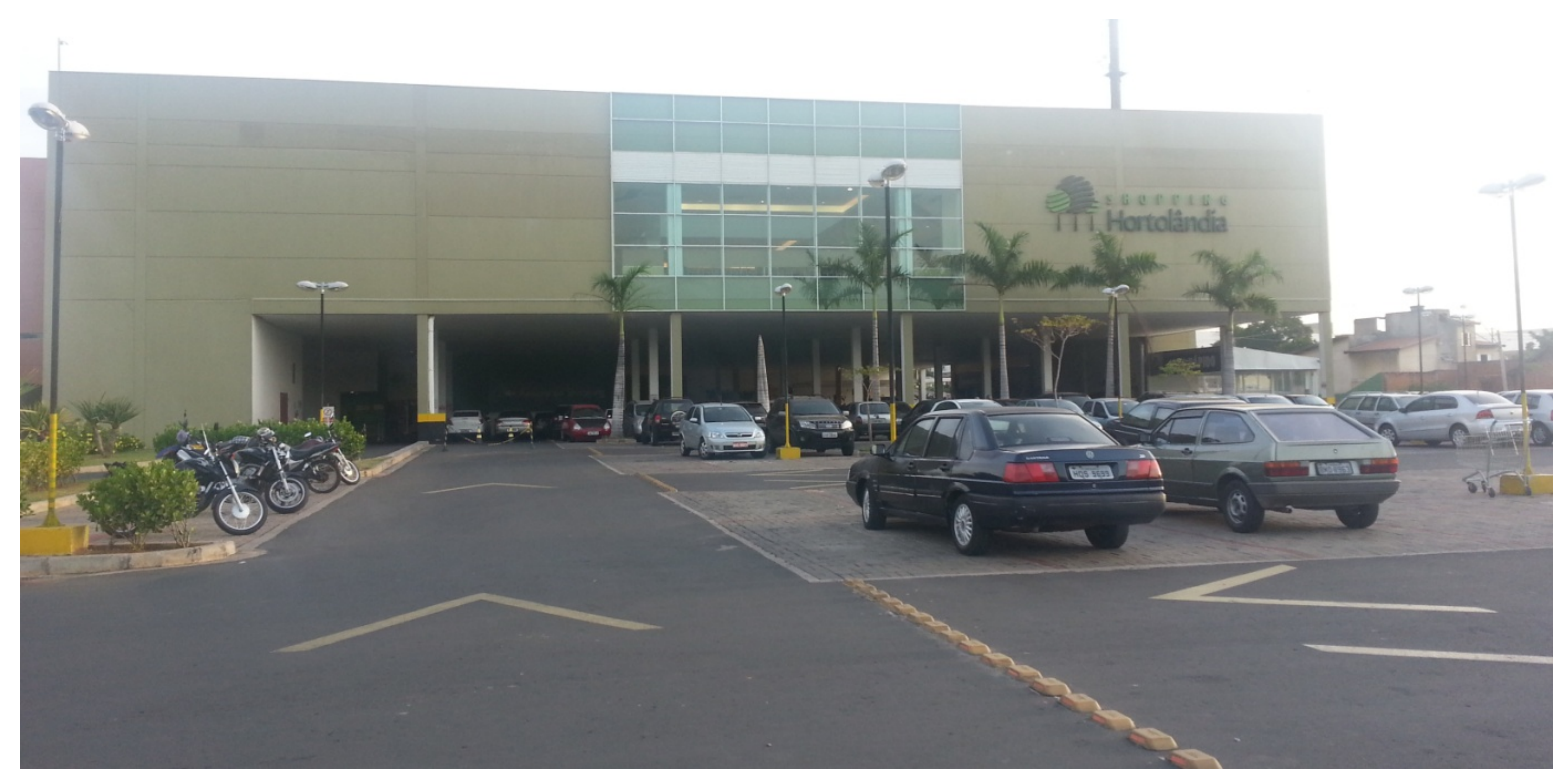

Figura 1 - Fachada do Shopping Hortolândia.

O cinema fica em um mezanino, relativamente isolado do restante do shopping. Isso dificultou um pouco a abordagem para as entrevistas, já que as pessoas não se mantinham nas imediações do cinema enquanto esperavam a sessão ou ao saírem dela. Não há área de espera ou bancos, então o fluxo é apenas o de compra e entrada/saída das sessões. A estrutura é nova, espaçosa e atraente, com vários totens dos filmes em exibição e por estrear, além de monitores LCD com os cartazes dos filmes e horários das sessões e do sistema de autoatendimento na bombonière e na bilheteria, como é possível observar nas figuras 2 e 3.

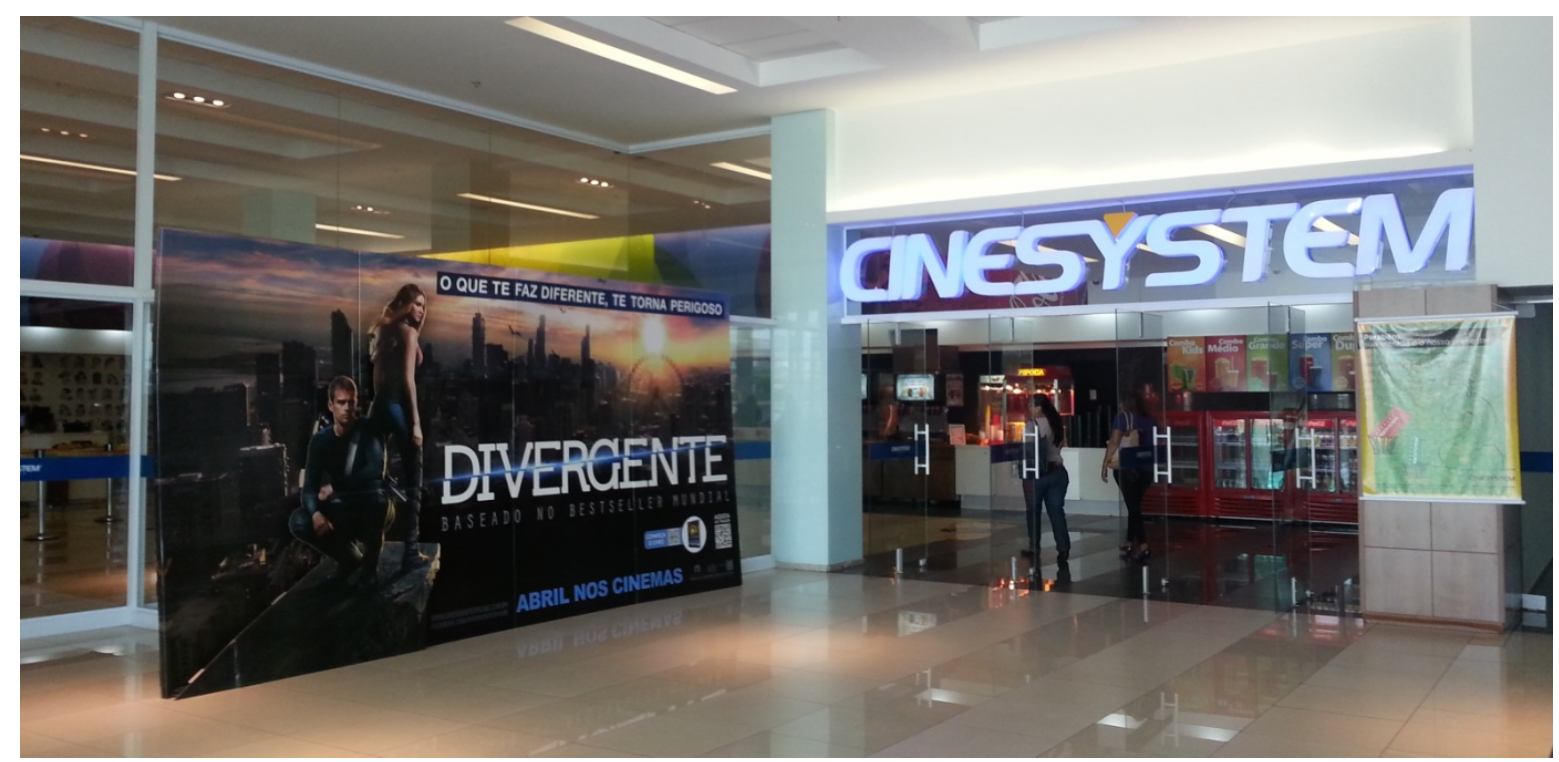

Figura 2 - Hall de entrada do Cinesystem Hortolândia. 


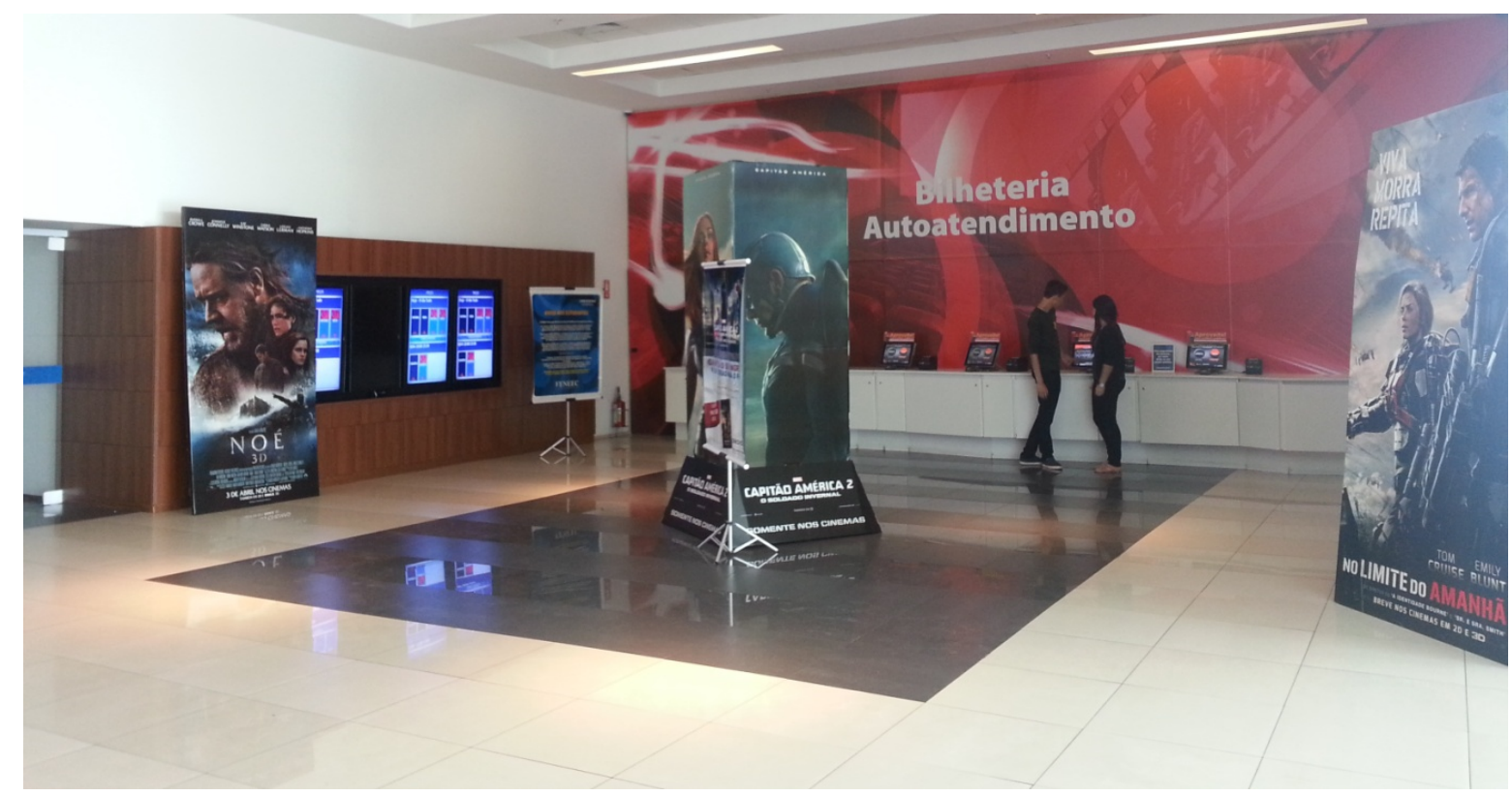

Figura 3 - Autoatendimento Cinesystem Hortolândia.

$\mathrm{Na}$ quinta-feira, as primeiras sessões tinham poucos espectadores, sobretudo de famílias com crianças e grupos de adolescentes. No início da noite, começaram a chegar vários casais, já que nesse dia da semana eles pagam um único ingresso. As pessoas foram receptivas às entrevistas, embora nem todas se prolongassem muito nas respostas. $\mathrm{Na}$ sexta-feira, o movimento foi semelhante, porém mais cheio no fim do dia. No fim de semana, o número de espectadores aumentou consideravelmente durante a tarde, mantendo o perfil de famílias e grupos de jovens. O shopping como um todo muda bastante de movimento ao se comparar os dias de semana e fim de semana. O estacionamento, normalmente vazio, chegou a ficar lotado no sábado e o fluxo nos corredores era intenso. Ainda assim, não presenciei nenhum momento de grandes filas no cinema, apenas filas moderadas (Figura 4).

Os filmes em cartaz naquela semana eram: Capitão América 2 - O soldado invernal, Rio 2 e Noé. Os ingressos nesta sala custavam de R\$ 13 a R\$20, variando de acordo com o dia da semana e com o tipo de sessão, se 2D ou 3D. Nas terças e quartas, todos pagam meia-entrada ( $\mathrm{R} \$ 6,50 / \mathrm{R} \$ 9)$ e, nas quintas, casais pagam um único ingresso. Assisti a uma sessão 3D de Rio 2, na segunda-feira. As instalações do cinema são novas e confortáveis e a projeção é de ótima qualidade. A sala estava com pouco mais de $25 \%$ de sua capacidade ocupada, a maior parte por uma excursão de crianças de 2 a 6 anos, trazidas até o local por um ônibus da prefeitura. A parceria faz parte do Projeto CinEscola, da Rede 
Cinesystem, que oferece ingressos a custos mais baixos para grupos escolares que queiram utilizar o cinema como recurso pedagógico.

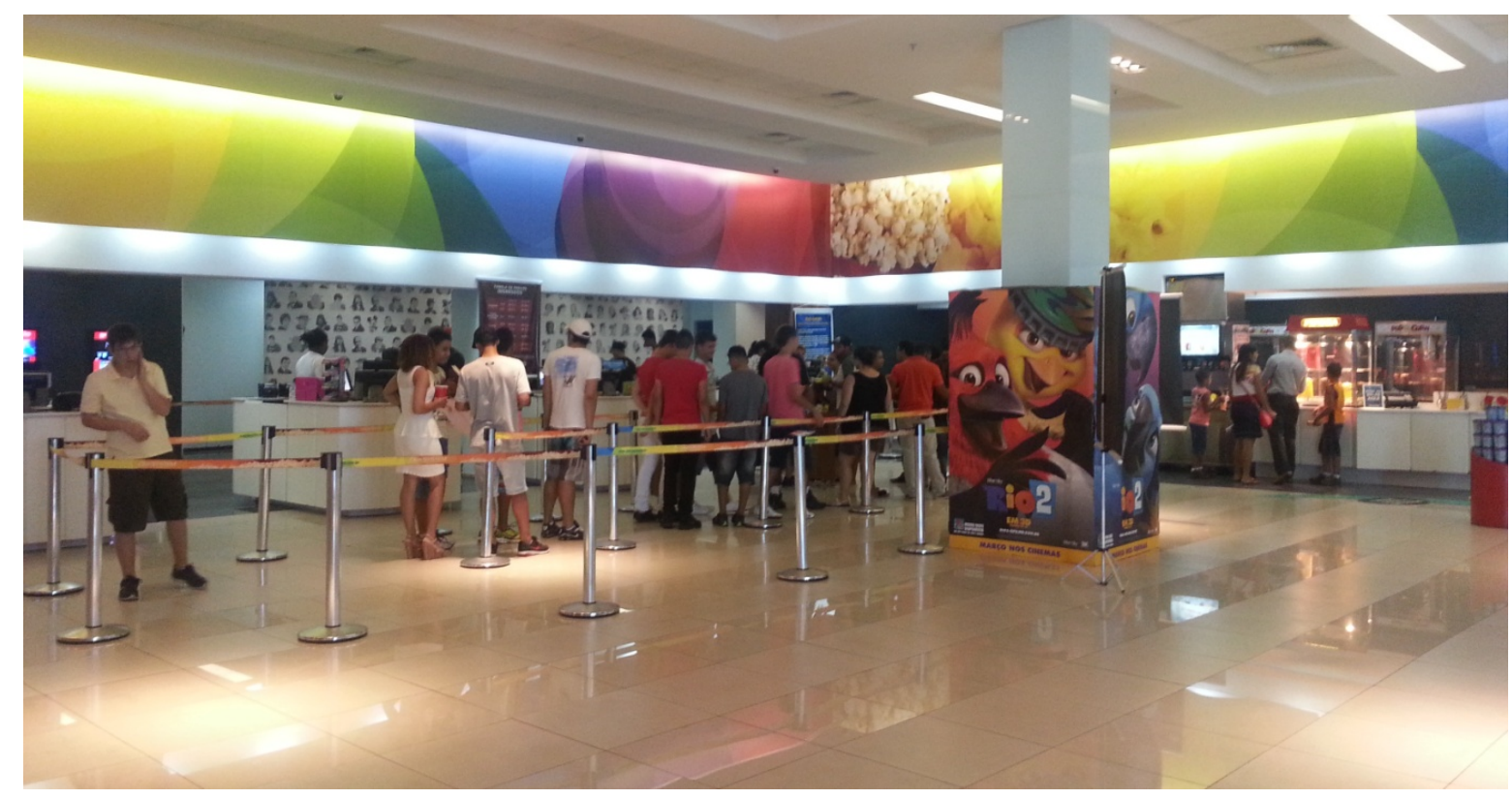

Figura 4 - Bilheteria do Cinesystem Hortolândia no sábado à tarde.

\subsubsection{Rio de Janeiro}

A cidade do Rio de Janeiro é a segunda maior metrópole do país e um dos principais centros econômicos, financeiros e culturais. A principal atividade econômica é o setor de serviços ( $85,5 \%$ do PIB), seguido pela indústria (14\% do PIB). Possui mais de 6 milhões de habitantes e o valor do rendimento médio mensal per capita é de R\$750 (dados do IBGE em 2010). O estado do Rio de Janeiro é a segunda unidade federativa com maior quantidade de salas de cinema (312 salas, em 2013), com 199 salas localizadas na capital, distribuídas em 44 complexos (dados da Ancine). Apesar da ampla oferta, a grande maioria das salas está concentrada na Zona Sul da cidade (entre a Barra da Tijuca e a Glória), portanto os bairros das zonas Norte e Oeste tornam-se aptos a pleitear os recursos do Cinema Perto de Você. Até julho de 2014, foram inaugurados 3 novos complexos financiados pelo programa, todos eles da Rede Cinesystem: Recreio Shopping, Via Brasil Shopping e Cine 10 Sulacap, sendo este último o eleito para a nossa pesquisa de campo, por conta do maior tempo de funcionamento. 
O Jardim Sulacap é um bairro da Zona Oeste do Rio de Janeiro, rodeado por uma grande área verde de floresta e por uma vila militar. Possui vários condomínios de prédios de médio porte e muitas casas, sendo uma área pouco verticalizada e de densidade habitacional consideravelmente menor que os bairros vizinhos de Realengo e Vila Valqueire. O Carrefour Sulacap, onde está localizado o Cine10, fica na principal avenida de ligação entre a Zona Norte e a Zona Oeste, onde passa a maior parte das linhas de ônibus do bairro. Ao lado do supermercado, há um campus da Universidade Estácio de Sá e o Parque Shopping Sulacap, inaugurado em outubro de 2013.

O Cine 10 Sulacap fica em frente à praça de alimentação do Carrefour (Figura 5). Inaugurado em 2010, foi a primeira sala contemplada pelo CPV, na época administrada pela Inovação Cinemas. Em 2012, foi comprado pela Rede Cinesystem, que o administra até o momento. O Cine 10 é o único cinema do bairro, porém não é o único da região. $\mathrm{A}$ uma distância de 8 a 15 quilômetros, há vários shoppings com cinema: Bangu Shopping, Shopping Jardim Guadalupe, Guadalupe Shopping e Madureira Shopping. A previsão é que, em 2015, mais 11 salas da Rede Cinesystem sejam abertas no Parque Shopping Sulacap, imediatamente ao lado do Carrefour. Segundo a administração local da sala, o Cine10 deve permanecer em funcionamento mesmo após a inauguração do complexo do Parque Shopping, porque atenderia a demandas de público distintas.



Figura 5 - Praça de alimentação e entrada do Cine 10. 
De todo modo, a estrutura física do Cine10 não apresenta a mesma qualidade e atrativos das outras salas da rede. Sua estrutura abrange 6 salas, sendo uma 3D, totalizando 1.373 assentos. A qualidade da projeção e das poltronas e o nível geral de conservação deixam a desejar se comparados às salas visitadas em Hortolândia e Imperatriz. A bombonière não utiliza o mesmo sistema de autoatendimento das outras salas e é consideravelmente menor, e não há sistema de autoatendimento para venda de ingressos, o que torna as filas congestionadas nos momentos de movimento mais intenso. As Figuras 6 e 7 mostram que a divulgação dos filmes e das promoções é feita por meio dos tradicionais cartazes em papel e banners, o que torna a própria estética da sala menos atraente que as demais salas da rede, que possui painéis de LCD com cartazes de filmes, programação e promoções. As opções de serviço e alimentação no Carrefour também são muito menores que as de um shopping. Além disso, dificilmente o Cine10 terá uma programação diferenciada, já que os filmes em cartaz são definidos pela administração central da rede. Portanto, a não ser que estabeleça valores de ingresso mais acessíveis, provavelmente não conseguirá dividir público com o novo complexo vizinho.

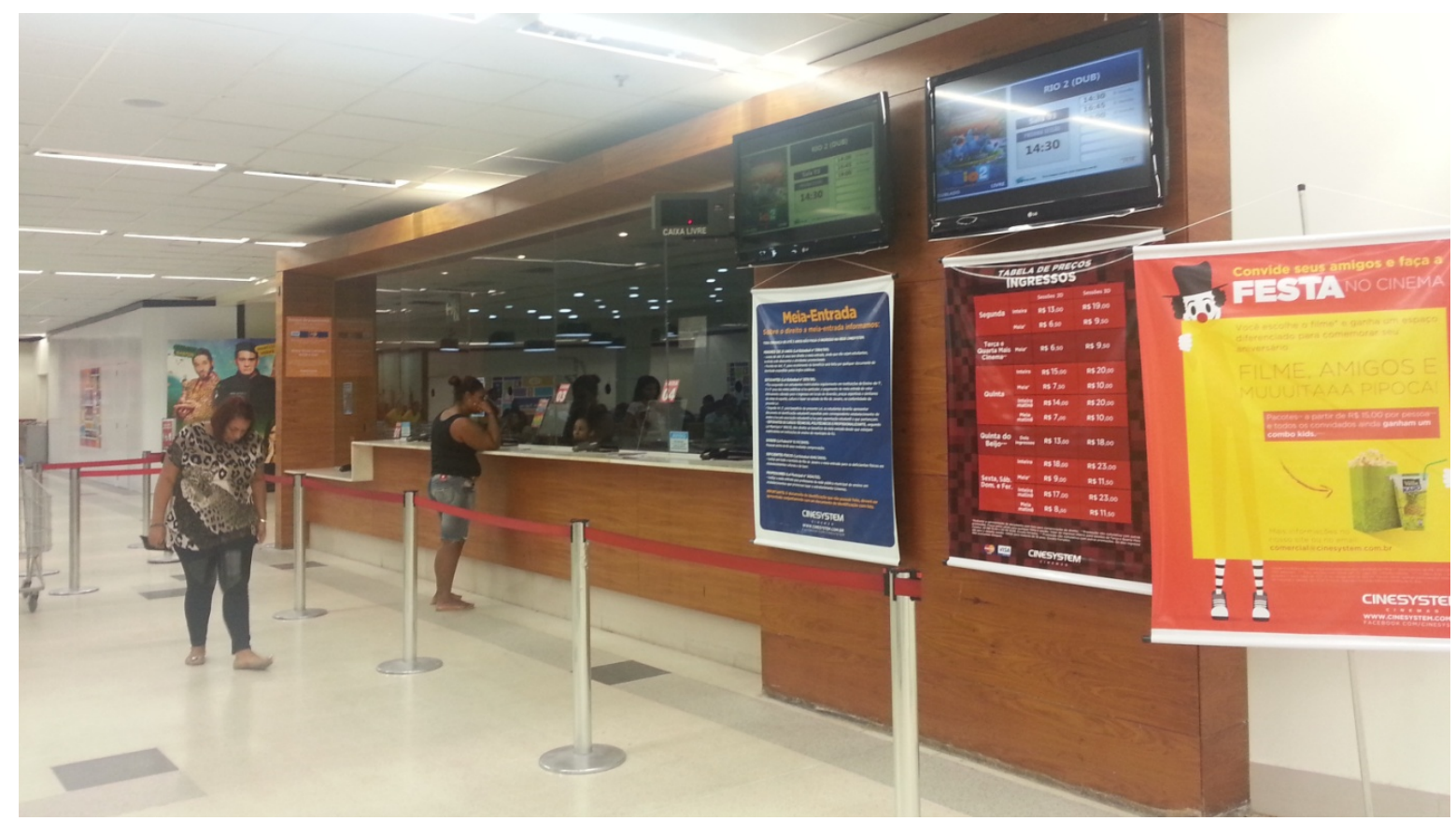

Figura 6 - Bilheteria do Cine 10. 


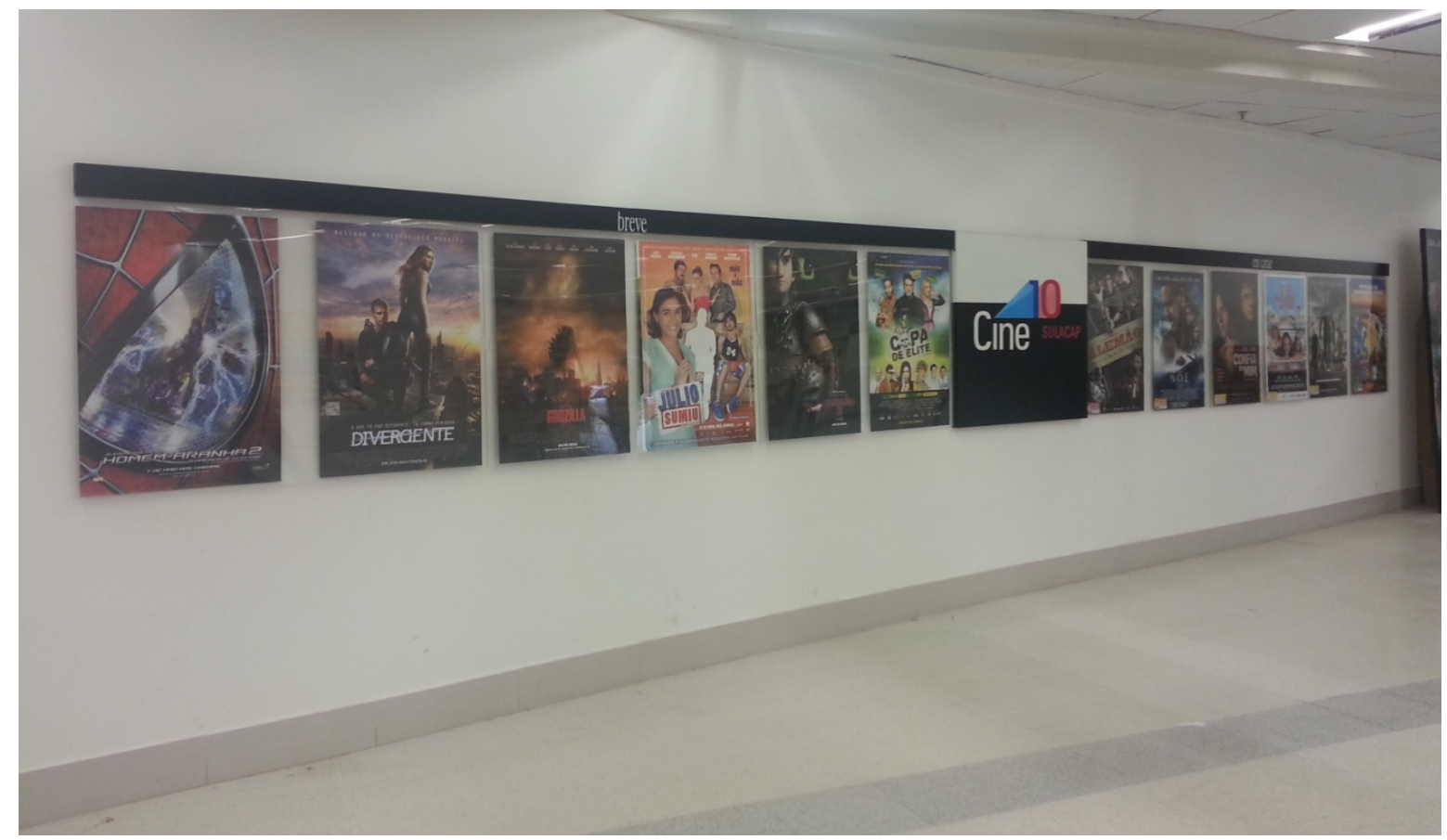

Figura 7 - Mural de cartazes do Cine 10.

Apesar dos bancos no hall de entrada das salas e da praça de alimentação, que permitem a permanência das pessoas nas imediações do cinema antes e após as sessões e, teoricamente, uma abordagem mais fácil, o público no Rio de Janeiro mostrou-se mais relutante em conceder as entrevistas. Também foi o público que se mostrou mais heterogêneo em relação aos hábitos relacionados ao cinema e à proximidade da moradia em relação à sala. Houve entrevistados que se mudaram para o bairro recentemente, outro que não ia ao cinema há mais de 20 anos, os que não têm o hábito de frequentar aquela sala, mas que a escolheram naquele momento porque passavam perto ou por conta de brindes dos filmes em estreia etc. Se, por um lado, essa heterogeneidade deixou algumas perguntas da entrevista sem aplicação, por outro, revelou que o perfil do público de uma cidade grande, com uma grande oferta de salas, tende a oscilar mais que o de uma cidade menor.

Durante a semana, o público vespertino era majoritariamente de adolescentes, mas também havia adultos, a maior parte mais velhos, possivelmente aposentados. No fim de semana, feriado e à noite, o movimento aumentava consideravelmente e o perfil de público também se diversificava: mais casais adultos, famílias com crianças, adultos de meiaidade. O público jovem, contudo, ainda era maioria. 
Assisti a uma sessão do filme brasileiro Confia em mim, em uma quarta-feira à tarde. Havia cerca de 15 pessoas na sala, todos adultos. Os filmes em cartaz durante a semana da visita foram: Capitão América 2 - O soldado invernal, Divergente, Noé, Rio 2, Júlio sumiu, Copa de elite, SOS mulheres ao mar e Confia em mim, sendo os 4 primeiros estrangeiros e os três últimos, brasileiros. Mesmo com apenas uma sala a mais que Hortolândia, o Cine 10 demonstra maior variedade e quantidade de filmes na programação. Os ingressos variavam de R\$ 13 a $\mathrm{R} \$ 23$, de acordo com o dia da semana e o tipo de sala, aplicando-se as mesmas promoções de meia-entrada para todos às terças e quartas e um único ingresso para casais às quintas-feiras.

\subsubsection{Imperatriz}

Imperatriz é a segunda cidade mais populosa do Maranhão, com aproximadamente 250 mil habitantes estimados em 2013 pelo IBGE. Está localizada no centro-oeste do estado, às margens do Rio Tocantins. O povoado que deu origem ao município foi fundado em 1852, por uma expedição jesuítica que saiu de Belém, e sua elevação à categoria de cidade ocorreu em 1924. Até o início da década de 1960, Imperatriz esteve distante geográfica e politicamente da capital do estado, São Luís, e só apresentou crescimento significativo após a construção da rodovia Belém-Brasília, quando se iniciaram fluxos migratórios de diversas procedências, o que resultou no crescimento acelerado da cidade nas últimas décadas. Atualmente, Imperatriz possui R \$ 2,2 milhões de PIB, sendo 78,7\% oriundos do setor de serviços e $17,8 \%$ da indústria. Cerca de $95 \%$ dos domicílios estão localizados na área urbana da cidade e a renda mensal média per capita é de $\mathrm{R} \$ 401,67$.

A cidade é bastante horizontal: muitos estabelecimentos comerciais de médio e pequeno porte e predominância de casas ou pequenos edifícios. A ocupação urbana demonstra certo planejamento, com uma malha de vias reticulada e, ao menos no centro, calçadas com rampas de acessibilidade a cadeirantes. Se as calçadas surpreendem positivamente, a quase completa ausência de áreas verdes ou árvores também chama a atenção, já que se trata de um local com média de temperatura de $27^{\circ} \mathrm{C}$. Durante a semana, o centro de Imperatriz apresenta certo caos causado pela quantidade de pessoas e carros,

com focos de engarrafamento e poluição automotiva e sonora. À noite e no fim de semana, 
a cidade se transforma: pouco ou nenhum fluxo nas vias, silêncio dominante, crianças brincam na rua, pessoas conversam sentadas em cadeiras nas calçadas.

O primeiro cinema da cidade foi inaugurado na década de 1950, mas era um espaço simples e pouco frequentado. Já na década de 1970, três grandes cinemas de rua estiveram em funcionamento, mas nenhum conseguiu vencer a crise do setor no fim da década de 1980, quando aos poucos foram fechando. Em meados dos anos 1990, surgiu o Cine Timbira, localizado no Shopping Timbira, no centro da cidade, que encerrou suas atividades em março de 2012. ${ }^{3}$ Atualmente, além do complexo de salas da Rede Cinesystem, contemplado pelo Cinema Perto de Você e inaugurado em maio de 2013, permanecem em funcionamento apenas as três salas do Shopping Tocantins. À parte do circuito de exibição comercial, Imperatriz possui dois cineclubes com atividades regulares: o Cinema no Teatro e o Cine Muriaquitã, organizados respectivamente pela Associação Artística de Imperatriz e pelo curso de Comunicação Social da UFMA, além da Mostra Audiovisual da Região Tocantina, que promove e incentiva a produção audiovisual local.

O Imperial Shopping, onde está localizado o complexo da Cinesystem Imperatriz, fica em uma região mais recente da cidade, às margens da BR 010. A imponência do empreendimento (Figura 8) destoa do mato acumulado ao longo da estrada, sobre a qual há precárias passarelas de ferro que ligam o restante da cidade ao novo bairro. Em frente há uma parada de ônibus, um ponto de táxi e mototáxi e um grande bicicletário, que esteve sempre repleto de bicicletas durante o período das visitas. O shopping é grande e, além das tradicionais franquias e lojas de departamento (Centauro, C\&A, Lojas Americanas, Riachuelo, Le Biscuit etc), apresenta lojas mais sofisticadas que as do Shopping Hortolândia.

\footnotetext{
${ }^{3}$ Informações obtidas no blog de Samuel Souza (samukaitz.blogspot.com), que escreve sobre a vida cultural da cidade.
} 


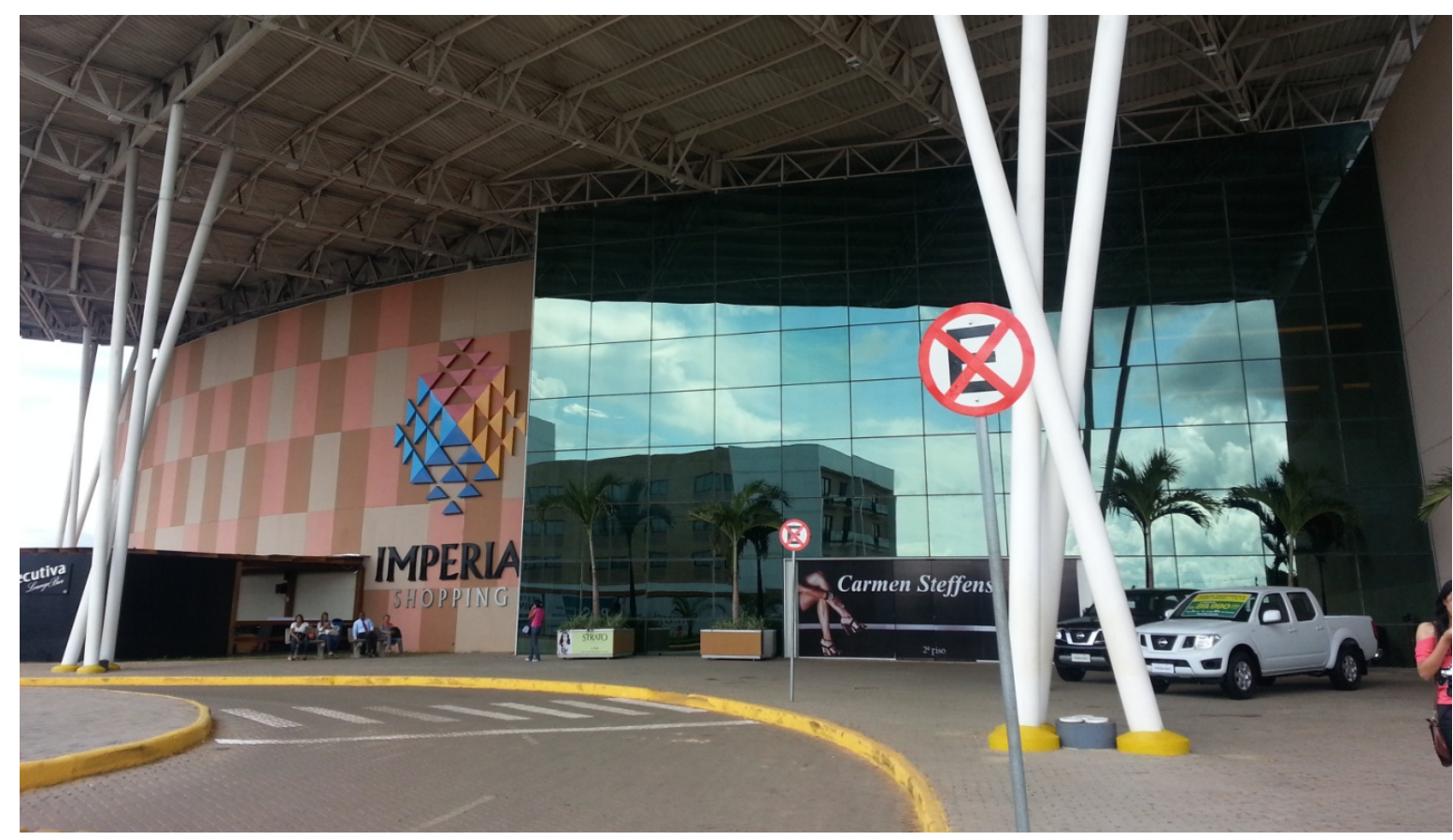

Figura 8 - Fachada do Imperial Shopping.

O cinema possui 5 salas (duas 3D), com um total de 1.225 lugares. A estrutura é inteiramente nova e apresenta o mesmo padrão de autoatendimento na bilheteria e na bombonière implementado pela Rede Cinesystem (Figura 9). Tanto durante a semana quanto no fim de semana, o movimento aparentou ser o mais baixo entre as salas visitadas, sendo o público principalmente de jovens. O fluxo na frente do cinema era grande, mas uma parcela pequena das pessoas que pegavam o folheto de programação ou olhavam os cartazes de fato comprava ingressos e entrava nas salas. A administração da sala confirmou que a média de público estava baixa e atribuiu isso ao fato de aquele ser o último fim de semana do mês, seguido de um feriado de Semana Santa e Tiradentes: "o movimento costuma ser maior no início do mês, quando as pessoas recebem os salários e ainda têm dinheiro sobrando. Muita gente veio no feriado e não tivemos nenhuma estreia nesta semana, por isso está mais vazio", afirmou a assistente administrativa Vanessa Basílio (2014).

Assisti a uma sessão 3D de Capitão América 2 - O soldado invernal, em uma quinta-feira à tarde. A sala tinha pouco mais de $20 \%$ da sua capacidade ocupada, majoritariamente por jovens rapazes. Tanto a estrutura da sala quanto a projeção foram de ótima qualidade. Os filmes em cartaz durante a semana da visita foram: Capitão América 
2, Divergente, O filho de Deus, Noé, Rio 2, Inatividade paranormal 2 e Júlio sumiu, sendo brasileiro apenas o último. Os ingressos variavam de R\$ 13 a R \$ 19, de acordo com o dia da semana e o tipo de sala, aplicando-se as mesmas promoções de meia-entrada para todos às terças e quartas e um único ingresso para casais às quintas-feiras.

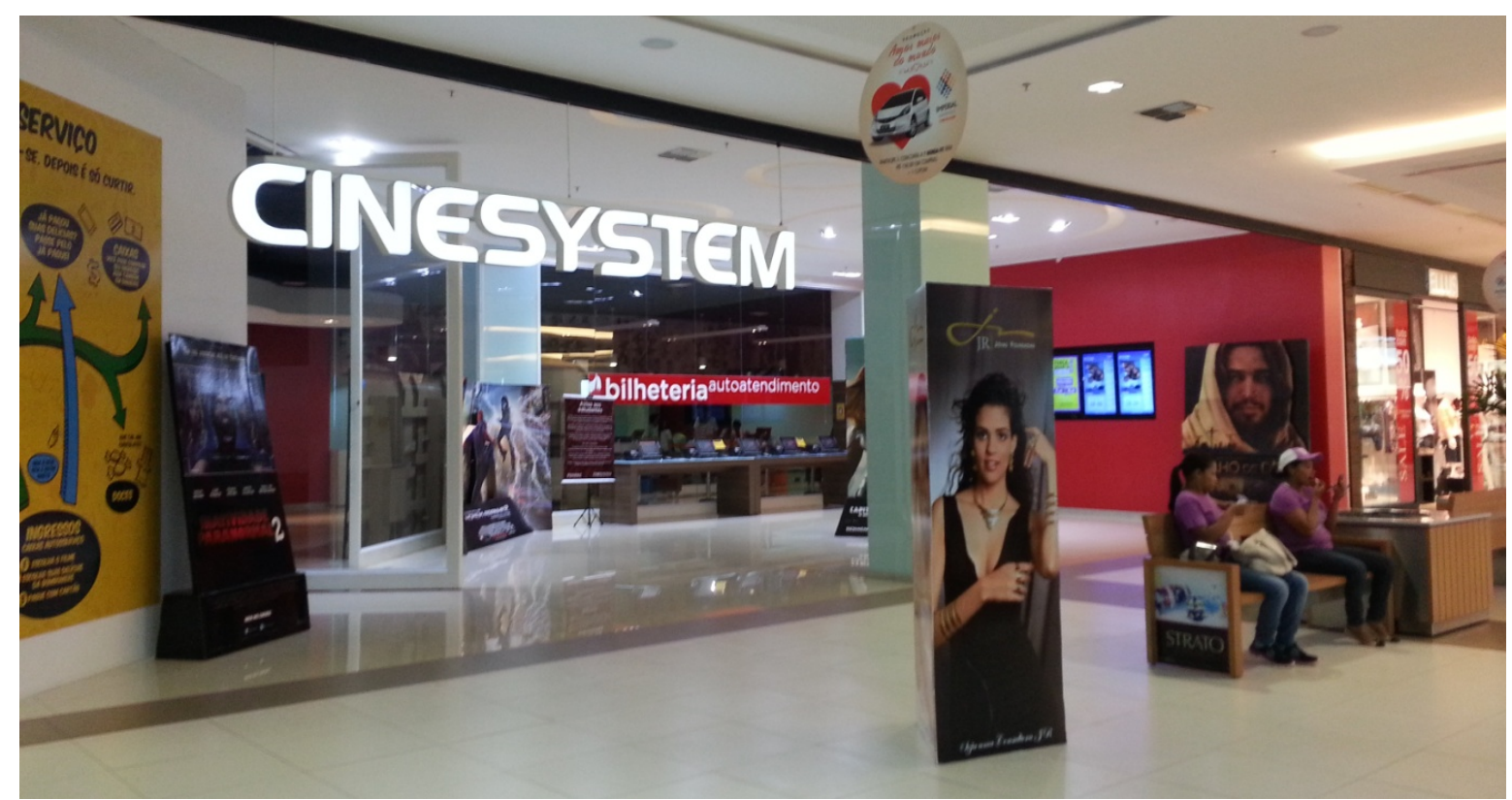

Figura 9 - Entrada do Cinesystem Imperatriz. 


\section{POLÍTICAS DE CINEMA NO BRASIL}

\subsection{Da cota de tela à Embrafilme}

Embora a atividade cinematográfica exista no Brasil desde princípios do século XX, foi somente na década de 1930, no primeiro governo de Getúlio Vargas, que se estabeleceu uma atuação sistemática do Estado não somente no cinema, mas na cultura em geral. O Estado criou legislações para as artes, radiodifusão, cinema, profissões culturais e constituiu diversos órgãos, como o Instituto Nacional de Cinema Educativo (INCE), o Serviço de Radiodifusão Educativa, o Serviço do Patrimônio Histórico e Artístico Nacional e o Conselho Nacional de Cultura (SIMIS, 2008).

Em 1932, o Decreto-Lei 21.240 criou a obrigatoriedade da exibição de um filme nacional para cada programa exibido nas salas de cinema, tornando-se o primeiro marco legal de proteção ao cinema nacional naquele momento. Essas intervenções, entretanto, não apontavam ainda para o estabelecimento da industrialização do setor, principalmente porque o foco era a produção/exibição de filmes de curta-metragem de cunho educativo.

Com o tempo, o cinema mostrou-se uma poderosa arma de propaganda e, em 1939, o governo Vargas instituiu o Departamento de Imprensa e Propaganda (DIP) que, além de exercer a censura, passou a produzir os filmes oficiais. Foi com o DIP que pela primeira vez se estipulou a obrigatoriedade de exibição dos filmes de longa-metragem. Contudo, como aponta Simis (2010, p.150), "mais que uma conquista, tal medida foi instituída como contrapartida quando os curtas independentes ganharam um novo competidor no espaço destinado à exibição compulsória: os filmes oficiais”. Apesar disso, e notadamente após dezembro de 1945, quando a cota de exibição passou de um para três longas por ano, houve um crescimento da produção de filmes deste formato (Gráfico 1).

Ainda na década de 1930, em um contexto de adaptação ao cinema sonoro e de grande concorrência com os filmes norte-americanos, surge a chanchada, um gênero nacional de amplo sucesso. Durante as décadas de 1940 e 1950, houve uma tentativa de construção de uma indústria cinematográfica nacional, por meio da criação de estúdios financiados pelo capital privado e desvinculados do Estado. A Atlântida consolida-se no mercado por conta da realização de filmes populares e baratos, enquanto a Vera Cruz, 
criada em 1949, passa a realizar grandes produções de elevados orçamentos, adotando um modelo baseado nos estúdios europeus e de Hollywood. (BAHIA, 2009, p. 21).

TOTAL DE LONGAS LANÇADOS POR ANO (1930 - 1965)

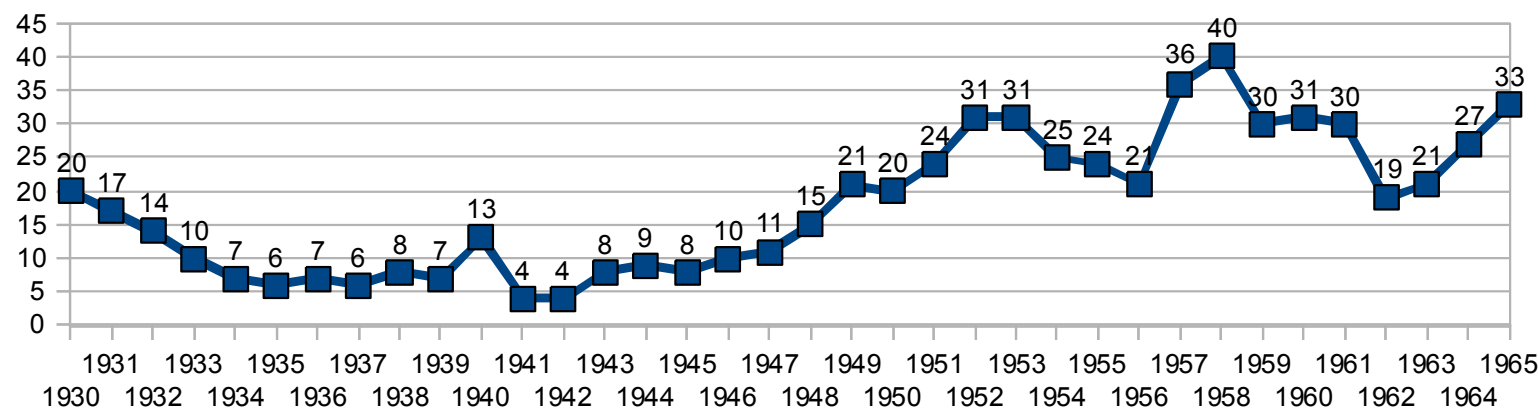

Gráfico 1 - Total de longas lançados por ano (1930-1965)

Fonte: Elaboração própria a partir de dados de Simis (2010).

Em decorrência do estágio primitivo da industrialização no país, do surgimento da televisão (e da consequente migração de produtores e técnicos para este setor), da má administração de recursos e, principalmente, da agressividade das estratégias de distribuição dos filmes norte-americanos no exterior, que viviam um momento de crise de público internamente, já em meados dos anos 1950 os grandes estúdios começam a entrar em falência: primeiro a Vera Cruz, precocemente, em 1954, e posteriormente a Atlântida, em 1962.

\begin{abstract}
Ao que parece, o governo brasileiro, ao não impor limitações à importação de filmes norte-americanos, [...] possibilitava que as majors pudessem exercer de forma plena a sua maior competitividade na distribuição, cujo fluxo volumoso e constante de lançamentos oferecidos seduzia e trazia evidentes vantagens comerciais ao parque exibidor nacional. (MATTA, 2004, p.161)
\end{abstract}

Já no início dos anos de 1950, com a precoce falência ou a dificuldade financeira de grandes empresas como Maristela, Vera Cruz e Multifilmes, ficou claro que a cota de tela não garantia a sobrevivência do setor e que não havia um projeto mais articulado para promover a indústria cinematográfica nacional. Nesse curto período democrático, entre os anos de 1945 e 1964, surgiram iniciativas como a do então deputado federal Jorge Amado, que propunha a criação do Conselho Nacional de Cinema, responsável pela regulamentação da produção, importação, distribuição e exibição de filmes no Brasil. A longa e polêmica tramitação do projeto, entretanto, descaracterizou seus aspectos 
democráticos e, a despeito das duas versões que tramitavam na Câmara, Vargas propôs a criação do Instituto Nacional do Cinema (INC), que só seria efetivamente estabelecido em 1966, após o golpe militar.

Com a criação do INC, o Estado passou a financiar a produção, valendo-se dos recursos oriundos de parte do imposto de renda das distribuidoras estrangeiras, e realizou 38 filmes em regime de produção associada durante os três primeiros anos de funcionamento do instituto (SIMIS, 2010, p.155). Embora o Estado tenha financiado projetos anteriormente, por meio de bancos ou empresas estatais, esta é a primeira vez que o financiamento acontece por meio de um órgão específico para o cinema. Os militares perceberam a importância estratégica do cinema e instituíram diversas medidas para incentivar e controlar a produção nacional, como a isenção de impostos sobre a importação de material e equipamentos cinematográficos e a ampliação do alcance da exibição nacional compulsória, que passou a atingir todas as salas de cinema das grandes cidades do país.

Criada em 1969, inicialmente como uma distribuidora de filmes brasileiros no exterior e atrelada ao INC, a Empresa Brasileira de Filmes S/A (Embrafilme) logo passou a ser responsável também pelo programa de financiamento de produção dos filmes nacionais de longa-metragem, iniciando o que viria a ser uma nova etapa no modelo de incentivo estatal ao cinema. Até 1973, o sistema de financiamento à produção previa que os recursos deveriam ser reembolsados à empresa após no máximo três anos, com juros de $4 \%$ ao ano. A falta de estrutura operacional para o gerenciamento dos incentivos, contudo, criou um estado de inadimplência generalizado.

A partir de 1974, com a fusão entre INC e Embrafilme e a nomeação de Roberto Farias como diretor da empresa, mudanças importantes aconteceram. A aproximação de integrantes do Cinema Novo com a diretoria da Embrafilme, no contexto da queda da "linha-dura" do governo militar e do início do processo de distensão, acena para uma participação maior do setor na política cinematográfica. Embora não houvesse identificação propriamente ideológica, o sentimento nacionalista era comum e a aproximação revelava-se como uma alternativa à produção eminentemente comercial dos produtores da pornochanchada. Porém, esse grupo restrito de cineastas relativamente consagrados seria beneficiado em detrimento de novos realizadores. 
Com o estabelecimento de uma distribuidora dentro da empresa, que passou a atuar no mercado nacional, surgiu uma nova forma de fomento à produção, que consistia na aquisição dos direitos relativos à comercialização da obra em até $30 \%$ de um orçamentoteto estabelecido e no adiantamento da renda relativa à bilheteria em até $30 \%$ do orçamento do filme. Dessa forma, como ressalta Tunico Amâncio (apud GATTI, 2007, p.93), a Embrafilme passa então "a produzir, financiar, promover, distribuir e premiar o filme brasileiro, além de cuidar de seu lado cultural, com orçamento ampliado por dotações, taxas e receitas diversas, todas advindas da própria atividade cinematográfica".

A partir do momento em que abandona a política de financiamento e se torna coprodutora, a Embrafilme passa a investir massivamente na distribuição dos filmes, já que era o seu sucesso comercial que iria garantir o retorno financeiro do investimento. A distribuição era, nesse momento, o grande entrave do mercado, pois havia uma ampla rede de exibição composta por mais de 3.200 salas espalhadas por todas as grandes cidades do país, o maior número registrado até hoje. Entre 1975 e 1976, a distribuidora da Embrafilme estabeleceu-se de forma definitiva no mercado, operando em escala nacional. O produtor brasileiro finalmente teve uma distribuidora focada no lançamento comercial de seus filmes, apesar de a abrangência da empresa e a forte concorrência terem levado as demais distribuidoras de filmes nacionais à falência ou a desistirem desse nicho de mercado.

Os altos investimentos em distribuição, em conjunto com outras ações, como a Lei da Dobra ${ }^{4}$ e a fiscalização ${ }^{5}$ mais rigorosa das bilheterias e do cumprimento da cota de tela (que chegou ao auge de 140 dias de filmes nacionais por ano nas salas), foram responsáveis pelo melhor desempenho que o cinema brasileiro já teve, não apenas em número de produções (mais de 800 longas-metragens lançados na década de 1970), mas também na frequência de público. O Gráfico 2 demonstra que a produção de longasmetragens aumentou consideravelmente na década de 1970 e manteve-se estável na década seguinte, e o Gráfico 3 apresenta o auge do número de salas em 1975, seguido por uma constante queda.

\footnotetext{
${ }^{4}$ Resolução $\mathrm{n}^{\mathrm{o}} 10$ do Concine, que permite a manutenção do filme brasileiro em cartaz na sua segunda semana de exibição, desde que ele tenha superado o índice de frequência semanal do cinema em questão no semestre anterior (GATTI, 2007, p.85).

${ }^{5} \mathrm{O}$ sistema de fiscalização, além de controlar a receita dos filmes, permitiu um retrato mais apurado do desempenho dos filmes nacionais. Até então, as informações repassadas pelos exibidores eram duvidosas.
} 
TOTAL DE LONGAS LANÇADOS POR ANO (1966-1990)

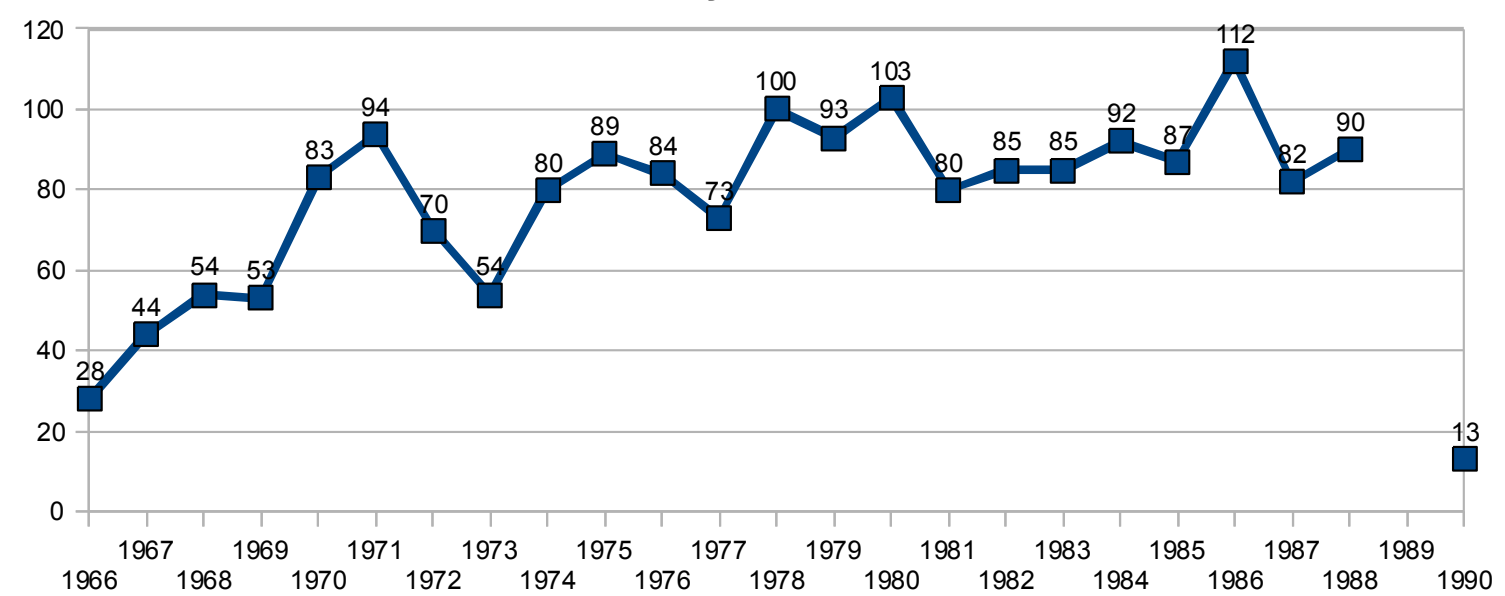

Gráfico 2 - Total de longas lançados por ano (1966-1990).

Fonte: Elaboração própria a partir de dados da Ancine e de Simis (2010).

*Não há dados sobre os lançamentos do ano de 1989.

TOTAL DE SALAS DE CINEMA POR ANO (1969-1990)

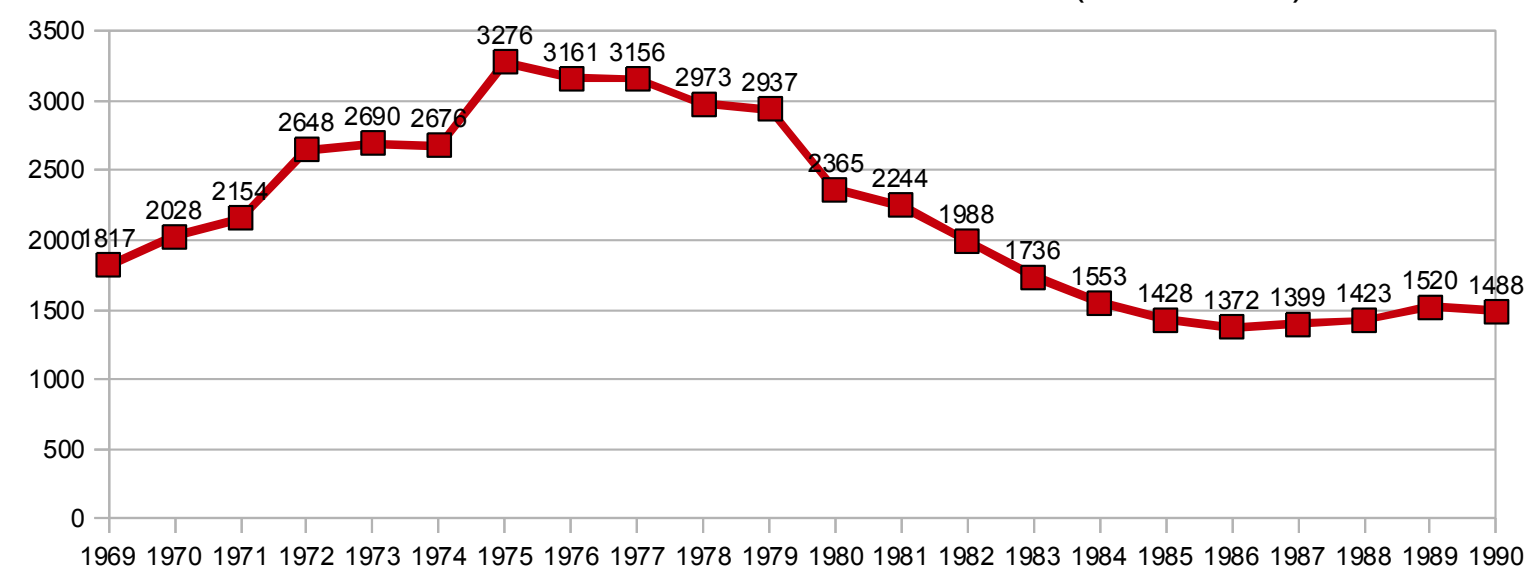

Gráfico 3 - Total de salas de cinema por ano (1969-1990).

Fonte: Elaboração própria a partir de dados da Ancine.

\subsection{Do desmonte da Embrafilme à Retomada}

Pelo sistema de coprodução utilizado, a Embrafilme passou a assumir todos os riscos do negócio. Isso, aliado às discrepâncias entre as estratégias de produção e distribuição dentro da Embrafilme, iria gerar fortes contradições. Segundo Gustavo Dahl, então diretor da distribuidora: 
chegou o momento no qual eu coloquei o fato de que o investimento maciço que estava sendo feito em produção não encontrava equivalente em comercialização [...]. Não havia uma política de mercado, havia uma política de produção, independente de uma política de mercado. (apud GATTI, 2007, p.34)

Na década de 1980, apesar de a produção brasileira conseguir se manter estável, houve uma acentuada queda de público, de receita de bilheteria e do número de salas de exibição. A crise econômica e a reorganização política que o país atravessava na segunda metade da década tiveram reflexos diretos em todo o mercado cinematográfico nacional, incluindo a Embrafilme. À crise financeira, somou-se uma crise institucional, diante das denúncias de má gestão administrativa e favorecimentos.

Em julho de 1986, com a criação da Lei Sarney, que dispunha sobre a renúncia fiscal para a realização de projetos culturais, os filmes da Embrafilme passam a concorrer com as outras artes pelas verbas de patrocínio para complementar seus orçamentos. Com a eleição de Fernando Collor de Mello, defensor de uma política de livre mercado, no início da década de 1990, assistimos à extinção das leis de incentivo e dos órgãos culturais no país. O Ministério da Cultura foi rebaixado à condição de secretaria, o Concine e a Embrafilme foram extintos e a legislação cinematográfica em vigor foi revogada. A exibição obrigatória de filmes nacionais foi reduzida para setenta dias e a presença nas videolocadoras caiu de $25 \%$ para $10 \%$. Nem mesmo os mecanismos de controle estatístico foram preservados.

Saímos de uma média de mais de 80 produções por ano, durante as décadas de 1970 e 1980, para menos de 10 lançamentos anuais na primeira metade da década de 1990. Perdemos nossa capacidade de produção e distribuição e, consequentemente, nosso público. Além da queda drástica de produção, a popularização da TV em cores e do vídeo doméstico em VHS afastou cada vez mais o espectador do cinema nacional.

Apesar de a Lei Sarney de incentivo à cultura via isenção fiscal ter sido reeditada pelo segundo secretário de cultura do governo Collor, Sérgio Paulo Rouanet, que deu seu nome à nova lei, foi somente durante o governo Itamar Franco que a atividade cinematográfica começou a ensaiar uma ressurreição. Itamar recriou o MinC e destinou a antiga verba da Embrafilme para a produção de 13 longas-metragens por meio do concurso Resgate do Cinema Brasileiro, enquanto a Lei 8.685/93, chamada de Lei do Audiovisual, tramitava no Congresso. Além disso, retomou a cota de tela e elaborou um projeto de 
financiamento para os filmes brasileiros, por meio de uma linha de crédito no BNDES, com juros subsidiados.

Mesmo após a aprovação da Lei do Audiovisual, em julho de 1993, foi somente a partir de 1995 que seus efeitos começaram a ser percebidos, cerca de um ano depois da implantação do Plano Real e da estabilização da economia no país. A lei, específica para o setor, permitia que até $60 \%$ do orçamento de projetos audiovisuais fossem captados a partir do investimento de parte do imposto de renda devido por pessoas físicas e jurídicas. Com a Lei do Audiovisual, a produção nacional voltou a crescer e gerou certa euforia no setor durante o período que ficou conhecido como Retomada.

As contradições da nova política de incentivo ao audiovisual, entretanto, não tardaram a aparecer. Criados para incentivar a iniciativa privada a investir em cultura, os mecanismos de isenção fiscal tiveram efeito inverso. Como aponta Dória (apud SIMIS, 2010, p.62), "um estudo sobre financiamento da cultura mostrou que o uso de recursos sofreu profunda transformação entre 1995, com 66\% das empresas e 34\% de renúncia fiscal, e 2000 , com $35 \%$ das empresas e $65 \%$ de renúncia fiscal".

Durante os dois mandatos do governo Fernando Henrique Cardoso, a política cinematográfica restringiu-se a aumentar a isenção fiscal. Em 1996, uma medida provisória aumentou o limite de dedução no imposto de renda de pessoas jurídicas de $1 \%$ para 3\%, dobrou o limite de captação, que passou de $\mathrm{R} \$ 1,5$ milhão para $\mathrm{R} \$ 3$ milhões, e ainda reduziu a contrapartida da empresa produtora de $40 \%$ para $20 \%$.

Em última instância, o investimento era público, mas a decisão de quais projetos patrocinar ficou restrita ao âmbito privado. As empresas ganhavam triplamente: reduziam os impostos a serem recolhidos, divulgavam suas marcas e, caso o filme gerasse lucros, ficavam com parte dos dividendos. Se os projetos não obtivessem sucesso comercial, não havia qualquer prejuízo financeiro para as empresas "investidoras".

Trata- se de uma apropriação gratuita do capital e da cultura pelos interesses privados, e ainda, com a fama creditada à iniciativa privada. No caso do cinema, se, por um lado, não há mais tutela do governo, com comissões que selecionam filmes capazes de obter recursos do Estado, por outro, o que conta é a capacidade do produtor de atrair uma empresa pagadora de impostos que, por sua vez, não corre qualquer risco. (SIMIS, 2007, p.145)

No fim do primeiro mandato de FHC, em 1998, o país atravessava uma grande crise econômica e o clima de euforia no setor esvaía-se. A imprensa denunciou esquemas 
de recompra de certificados de investimento nos projetos pelos próprios produtores. $\mathrm{Ou}$ seja, o investidor deixava de pagar impostos, divulgava sua marca e ainda obtinha lucros com a revenda. Para conseguir recomprar os certificados, os filmes estavam sendo superfaturados e os custos de produção cresciam sensivelmente. Apesar de legal, a recompra dos certificados gerou polêmica e os produtores apoiavam-se na alegação de que não havia critérios mais rígidos do Estado para classificar os projetos aptos à captação, culpando a permissividade da legislação pela existência de oportunistas e pela inconclusão de vários filmes.

Depois, no momento da primeira crise e quando a produção se depara com dificuldades, o campo cinematográfico começa a criticar esse mecanismo, esquecendo-se que participou da criação dessa política cinematográfica e que a legislação de renúncia fiscal já trazia estes problemas desde sua concepção. (MARSON, 2006, p.119)

Em meio à crise, que se agravou com a privatização das empresas de telecomunicações, tradicionais investidoras do cinema brasileiro, o setor volta a se organizar e realiza o III e o IV Congresso de Cinema, em 2000 e 2001, reivindicando a elaboração de uma política audiovisual mais abrangente e contínua. O governo convoca então o GEDIC (Grupo Executivo de Desenvolvimento da Indústria Cinematográfica), que apresenta as propostas que culminaram na criação da Política Nacional de Cinema e na Medida Provisória 2228-1/01, que redesenha o setor audiovisual em um tripé institucional.

Caberia ao Conselho Superior de Cinema, órgão de estrutura paritária entre representantes do governo e da sociedade civil, incluindo membros da classe, a formulação da política nacional para o audiovisual. Já a execução dessa política ficaria a cargo da Ancine, responsável pelo fomento, regulação e fiscalização do setor, e da Secretaria do Audiovisual (SAv), que sofreu uma reorganização e passou a se dedicar mais à denominada "área cultural" do cinema, com programas e editais voltados para a produção de curtas-metragens e longas de baixo orçamento, além de ações de difusão e preservação da memória cinematográfica (IKEDA, 2011).

Criada em 2001, a Ancine só começou a funcionar efetivamente a partir de 2003, já durante o governo Lula, contando com recursos da Condecine, taxa sobre a publicidade e o cinema (nacional e estrangeiro) comercializados no Brasil. A agência passou a fiscalizar as leis de incentivo e a fomentar a indústria, além de se responsabilizar pelos relatórios, dados e estatísticas do cinema nacional, ampliando o acesso à informação. 
Em 2004, houve a tentativa de transformação da Ancine em Ancinav (Agência Nacional do Cinema e do Audiovisual), que previa a expansão de suas funções para outros meios, como televisão e mídias eletrônicas, visando atender ao cenário de convergência midiática e tecnológica que já se impunha naquela época. Em meio a uma conturbada negociação, a proposta fracassou, diante de críticas de parte do próprio setor audiovisual, mas principalmente cedendo às pressões dos setores de radiodifusão e comunicação eletrônica de massa, cujos interesses viram-se ameaçados (IKEDA, 2011, p.246).

Mais recentemente, em 2007, a criação do Fundo Setorial do Audiovisual (FSA), categoria específica do Fundo Nacional de Cultura, interferiu na estrutura da Ancine, à medida que os recursos da Condecine e ainda a parcela do Fistel (Fundo de Fiscalização das Telecomunicações) destinada à agência foram direcionados para o FSA. Os recursos do fundo, que contemplam o estímulo a diversos segmentos da cadeia produtiva do setor, juntamente com o fortalecimento dos programas do Ministério da Cultura, trouxeram de volta para o âmbito do Estado o arbítrio do destino de parte da verba pública de incentivo ao audiovisual. Atualmente, são cerca de R\$ 1 bilhão disponível via FSA, voltado para desenvolvimento de projetos, capacitação e formação profissional, produção e difusão de conteúdos brasileiros e expansão do parque exibidor.

\subsection{Da verdadeira retomada da produção aos desafios da difusão e do acesso}

$\mathrm{Na}$ última década, como apontam Chalupe (2010) e Moura (2010), após a consolidação dos mecanismos de incentivo responsáveis pela retomada do cinema nacional, o Estado conseguiu interferir em um dos elos da cadeia, o da produção. No entanto, a distribuição e a exibição concentraram-se durante a década de 1990 sob o controle do capital estrangeiro, com a implementação de um novo modelo de negócio no setor de exibição, os multiplexes. Esses conglomerados, se por um lado contribuíram para o crescimento do número de salas (saímos de 1.033, em 1995, para 2.830 em 2014), apresentam, por outro, uma forte concentração: as salas registradas em 2014 compõem 747 complexos, em sua maioria localizados em shoppings e em cidades com mais de 500 mil habitantes (dados da Ancine). 
A partir da leitura dos gráficos 4 e 5, é possível perceber que o montante de investimento no setor cinematográfico e o número de filmes lançados por ano cresceram consideravelmente.

INCENTIVO FEDERAL AO AUDIOVISUAL NACIONAL (em milhões)

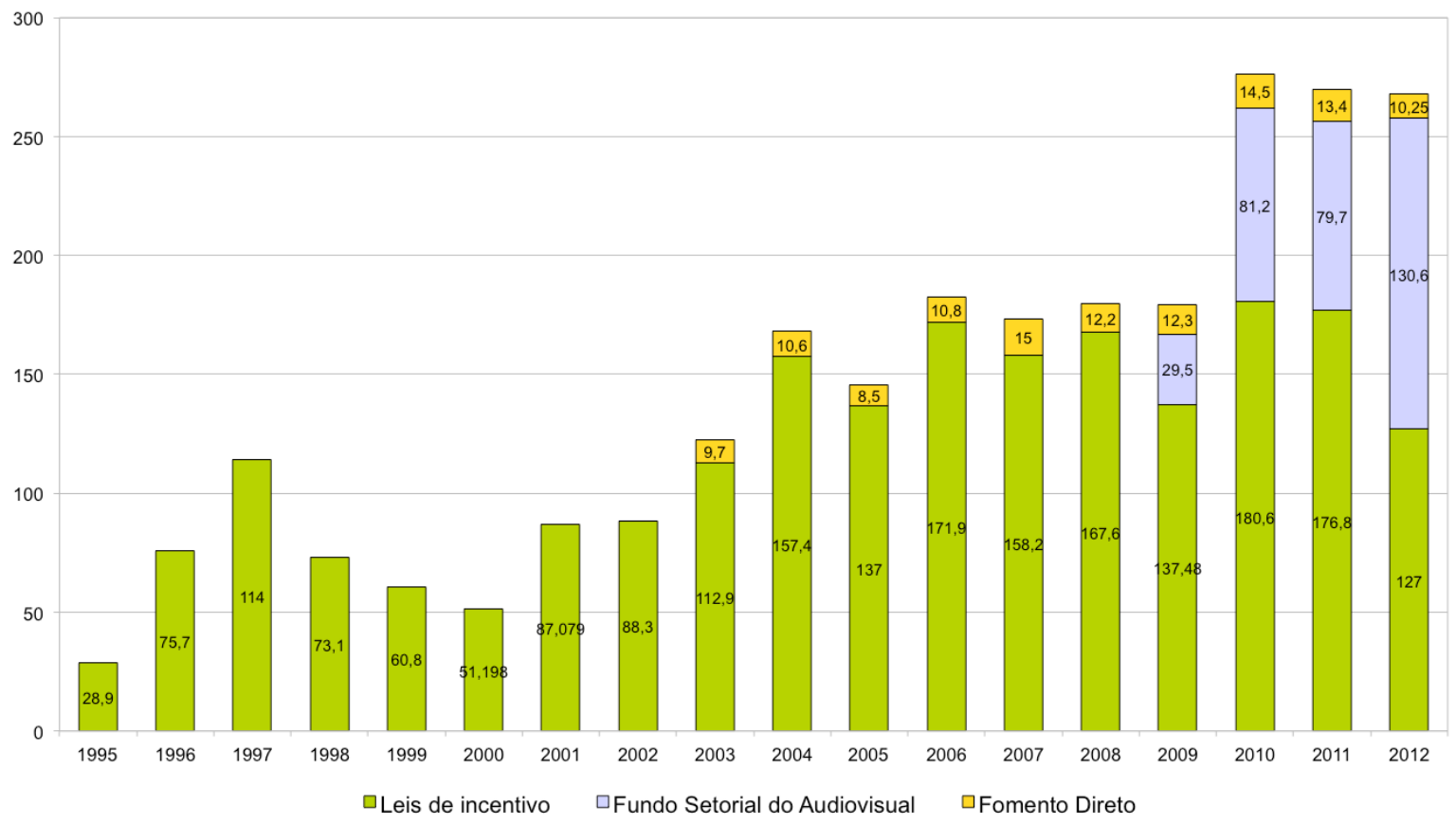

Gráfico 4 - Incentivo federal ao audiovisual nacional (em R \$ milhões).

Fonte: Borges (2007), de 1995 a 2000; Ancine, de 2001 a 2012.

* Até a finalização da pesquisa, a Ancine não havia divulgado os dados consolidados de 2013.

TOTAL DE LONGAS LANÇADOS POR ANO (1995-2014)

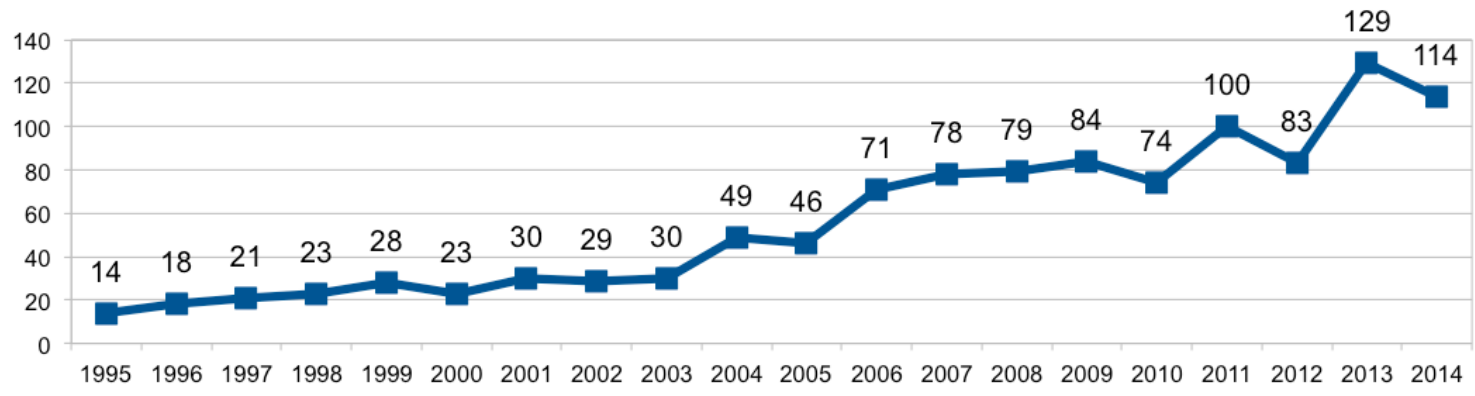

Gráfico 5 - Total de longas lançados por ano (1995-2014).

Fonte: Elaboração própria, a partir de dados da Ancine. 
Por outro lado, o aumento de público do cinema nacional nas salas de exibição não acompanha o crescimento do investimento e do número de produções lançadas, não chegando a ultrapassar a média de $15 \%$ do público total. As exceções ocorrem devido ao sucesso de público de títulos isolados, como Carandiru (4,7 milhões de espectadores) e Lisbela e o prisioneiro (3 milhões), em 2003, Tropa de elite 2 (11 milhões) e Nosso lar (4 milhões), em 2010, e Minha mãe é uma peça (4,6 milhões), De pernas pro ar 2 (3,8 milhões) e Meu passado me condena (3 milhões), em 2013.

\section{PÚBLICO DO CINEMA NACIONAL EM SALAS DE EXIBIÇÃO (1995-2014)}

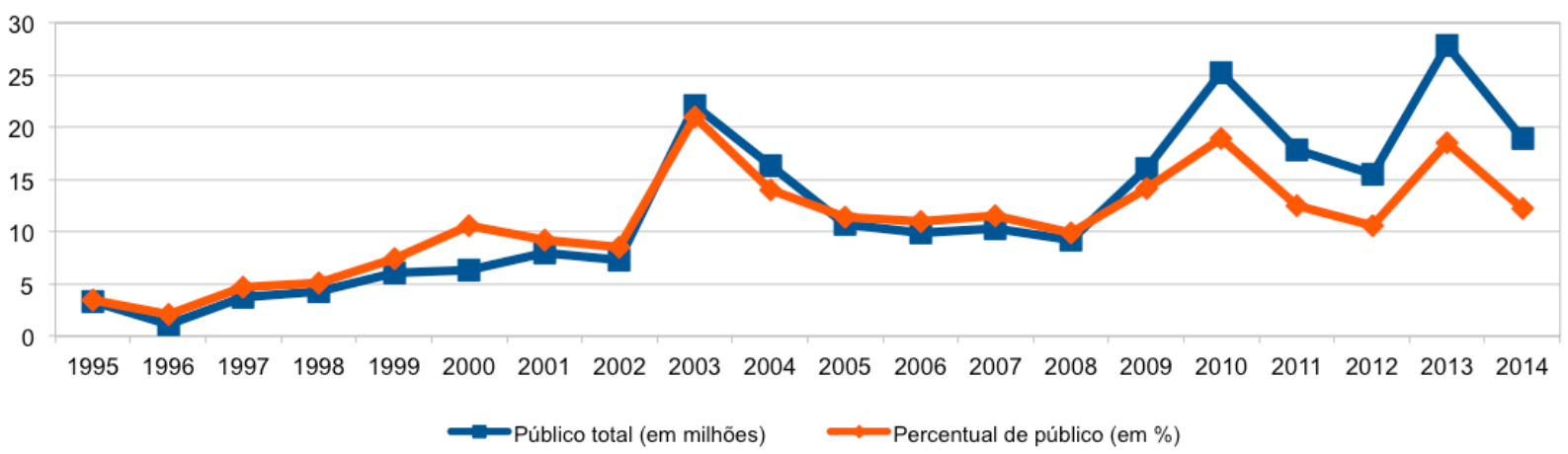

Gráfico 6 - Público do cinema nacional em salas de exibição (1995-2014). Fonte: Elaboração própria, a partir de dados da Ancine e de relatórios da SAv.

Neste cenário, vale ressaltar a participação dos filmes produzidos ou coproduzidos pela Globo Filmes. Criada em 1998, apesar de não poder utilizar os mecanismos de incentivo pelo fato de fazer parte do mesmo grupo empresarial da emissora de televisão, a Globo Filmes tem se associado a produtoras independentes, aptas à captação, e detém as maiores bilheterias do cinema nacional desde a Retomada. Na última década, 95\% dos filmes com mais de um milhão de espectadores foram coproduzidos ou apoiados pela Globo Filmes, praticamente todos financiados pelas leis de incentivo. Dessa forma, além de possuir a rede de televisão de maior audiência nacional, as Organizações Globo monopolizam também o público do cinema brasileiro nas salas de exibição, utilizando-se da sua penetração como emissora, dos atores e programas consagrados na sua grade e de publicidade massiva.

Ao partirmos para a análise da presença do cinema nacional em outras janelas (Gráfico 7), percebemos que ele não ultrapassou a média de $10 \%$ do total de lançamentos 
no mercado de vídeo doméstico (DVD), nem de 16\% do total de longas-metragens exibidos nas televisões abertas e por assinatura nos últimos anos.

\section{CINEMA NACIONAL NA TELEVISÃO E VÍDEO DOMÉSTICO (2008-2013)}

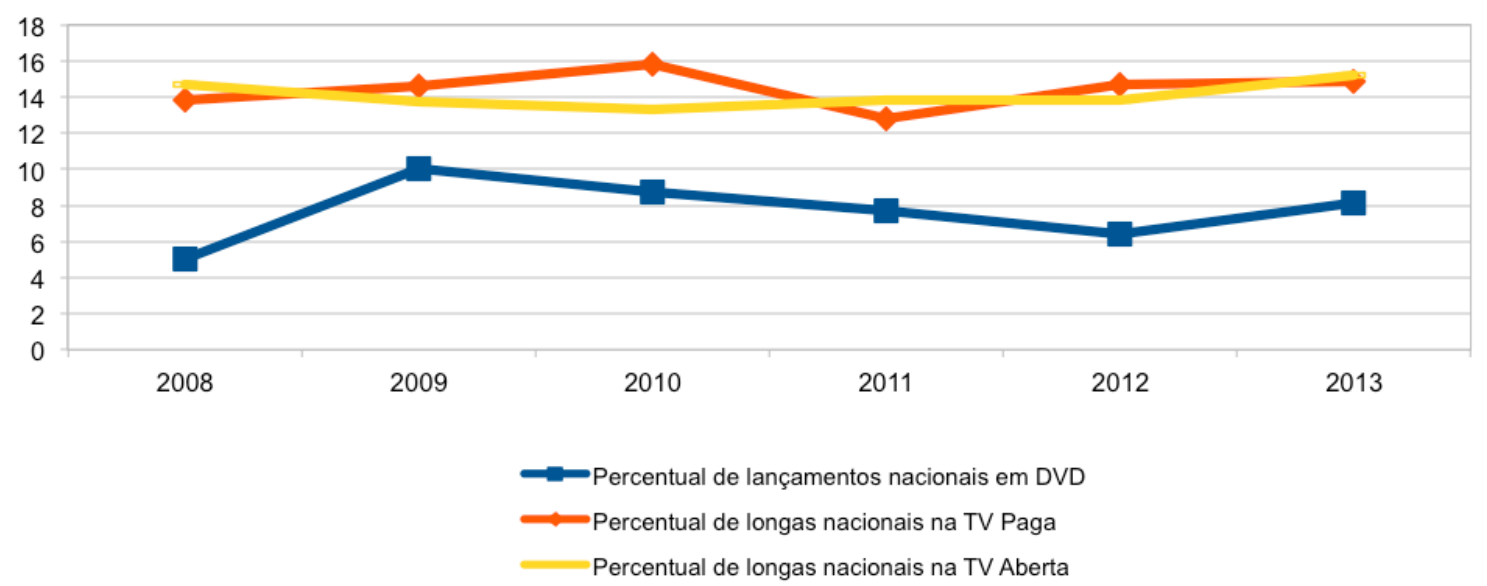

Gráfico 7 - Cinema nacional na televisão e vídeo doméstico (2008-2013). Fonte: Informes Anuais de Acompanhamento de Mercado da Ancine.

Esse panorama demonstra a fragilidade das políticas cinematográficas vigentes principalmente no que tange à distribuição e exibição do filme nacional. Para além do que pode ser constatado a partir de dados numéricos, estudos como os de Ikeda (2011) e Borges (2007) apontam que esses setores estão sob domínio dos grandes conglomerados internacionais de entretenimento, o que se constitui uma barreira à expansão da difusão do cinema nacional. As multinacionais dominaram não apenas o mercado de distribuição dos filmes estrangeiros, como também boa parte do mercado brasileiro, especialmente depois que o Artigo $3^{\circ}$ da Lei do Audiovisual passou a permitir que essas empresas investissem até $70 \%$ do imposto de renda devido na coprodução de obras audiovisuais brasileiras independentes. O filme nacional, entretanto, representa um produto secundário na estratégia de mercado das multinacionais e são interessantes apenas na medida em que gerem um bom percentual de lucro e não concorram com o produto estrangeiro, que é o foco da distribuição:

Está claro, portanto, que o domínio do setor de distribuição cinematográfica no Brasil pelas majors internacionais provoca uma forte dependência econômica e comercial dos produtores em relação aos distribuidores. Por isso, esse setor merece especial atenção na elaboração de políticas de incentivo à indústria cinematográfica nacional porque, como se pôde concluir, um ritmo estável de produções nacionais, como o que manteve o país entre 1995 e 2005, não 
significa por si só uma indústria nacional auto-suficiente. (BORGES, 2007, p.124)

Conforme mencionado, a partir da criação da Ancine, da reestruturação da SAv e, principalmente, após a criação do FSA, é possível perceber um esforço no sentido de aumentar e diversificar os mecanismos de incentivo ao audiovisual. Após a consolidação das políticas voltadas principalmente para a produção, a questão da difusão dos filmes começa a assumir papel importante na discussão. Um mapeamento indica quais as leis e programas que preveem ações de difusão do cinema, a saber:

- Lei 8.313/91 (Lei Rouanet): Prevê incentivos à construção e manutenção de salas de cinema ou centros comunitários com salas de cinema em localidades com até $100 \mathrm{mil}$ habitantes, à difusão de acervo audiovisual (não restrita a obras nacionais) e à distribuição e exibição cinematográficas de obras individuais ou conjunto de obras.

- Lei 8.685/93 (Lei do Audiovisual): Além de permitir a aplicação de parte do imposto de renda na realização de obras cinematográficas de produção independente, mediante aquisição de direitos de transmissão por radiodifusão ou de quotas de direitos de comercialização, a lei prevê a utilização dos incentivos fiscais por projetos credenciados pela Ancine voltados para difusão, preservação, exibição, distribuição e infraestrutura.

- Lei 12.485/2011: Dispõe sobre a comunicação audiovisual de acesso condicionado, que inclui as chamadas TVs pagas ou por assinatura. Entre diversas medidas, a lei regulamenta o espaço que o conteúdo audiovisual brasileiro deve ocupar dentro da programação dessas TVs.

- Linhas do FSA: Relacionado à difusão, o Fundo Setorial do Audiovisual prevê: investimento em produção independente de obras para televisão, desde que o proponente apresente contrato com emissora ou programadora de TV; aquisição de direitos de distribuição de longas-metragens de produção independente para exploração comercial em todos os segmentos de mercado, com utilização dos recursos na produção da obra; investimento em comercialização de obras brasileiras de longa-metragem de produção independente para exibição em salas de cinema, desde que apresentem contrato de distribuição.

- Programadora Brasil: Programa da SAv coordenado pela Sociedade de Amigos da Cinemateca Brasileira, que visa ampliar o acesso às produções recentes e aos filmes 
representativos da cinematografia nacional que estão fora do circuito de exibição. No final de 2012, a Programadora contava com mais de 1.650 instituições associadas (escolas, universidades, cineclubes, organizações sociais, pontos de cultura etc), em cerca de 850 municípios de todos os estados do país, atingindo 6,5\% a mais de municípios que as salas comerciais de exibição. O último catálogo reúne 825 filmes de todos os gêneros e duração, organizados em 255 programas em DVD. Em agosto de 2013, o programa foi descontinuado devido a uma crise institucional e financeira que resultou na suspensão do repasse de recursos da SAv para a Sociedade de Amigos da Cinemateca e na demissão dos funcionários da Programadora.

- Cine Mais Cultura: Programa do Ministério da Cultura voltado a entidades públicas e privadas sem fins lucrativos, que desenvolvam ações de exibição de filmes e formação de público, para a instalação de infraestrutura de exibição com tecnologia digital. A ênfase prioritária dos cineclubes deverá ser a exibição não comercial das obras audiovisuais brasileiras de produção independente.

- Cinema Perto de Você: Programa voltado para o incentivo à ampliação, diversificação e descentralização do mercado de salas de exibição cinematográfica no Brasil, por meio de linhas de crédito e investimento para implantação de complexos de exibição e medidas tributárias de estímulo à expansão e à modernização do parque exibidor de cinema.

Dessa forma, é possível perceber que a Programadora Brasil, o Cine Mais Cultura e o Cinema Perto de Você são os programas que possuem foco principal de atuação no acesso ao cinema. Os dois primeiros, entretanto, apresentam problemas de continuidade, além de dispersão e imprecisão dos dados de investimento e exibição, o que torna difícil a tarefa de tentar aferir e analisar suas contribuições e impactos sobre o acesso às obras audiovisuais de maneira mais aprofundada. O Cinema Perto de Você, por atuar na cadeia de cinema tradicional e por estar subordinado à Ancine, que possui mais capacidade de recolhimento e compilação dos dados, apresentou-se como o objeto de pesquisa mais adequado aos propósitos e questões desta investigação.

Instituído pela Lei 12.599/2012, o programa visa diversificar, descentralizar e expandir a oferta de serviços audiovisuais para a população brasileira, com foco na 
inclusão de espectadores da classe $\mathrm{C}^{6}$, por meio da ampliação do parque exibidor de cinema, fortalecendo as empresas e o segmento de exibição cinematográfica e facilitando o acesso às obras audiovisuais a partir da abertura de salas em cidades de porte médio e em bairros populares das grandes cidades. Entre as metas do programa, destacam-se:

- abertura de 600 novas salas de cinema com base nos recursos do programa;

- nenhum município com mais de 100 mil habitantes sem sala;

- média nacional de 60 mil habitantes por sala, queda de 30\% do índice em 2011;

- crescimento de 30\% na venda de ingressos;

- digitalização de metade das salas de cinema do país.

Os recursos do Fundo Setorial do Audiovisual são disponibilizados em duas modalidades de operação financeira: empréstimo e investimento. $\mathrm{O}$ investimento envolve um contrato de participação do FSA nos ganhos com os resultados comerciais do empreendimento. O empreendedor poderá tomar recursos de empréstimo ou das duas modalidades conjuntamente e qualquer empresa com sede e administração no país pode propor projetos.

O programa visa enfrentar também outros desequilíbrios, como a concentração geográfica das salas, com estímulos especiais para as regiões Norte e Nordeste e para as cidades do interior mal atendidas por salas. Os municípios carentes de salas de cinema foram divididos em quatro grupos (Quadro 4), de acordo com o tamanho da população residente e a disponibilidade de cinemas. Essa classificação determina a origem dos recursos e a composição dos instrumentos financeiros disponíveis em cada caso, bem como a organização das prioridades de investimento e financiamento do fundo.

Nos municípios com menos de 100 mil habitantes, a viabilização de uma sala de cinema envolve uma equação econômica e financeira mais complexa, por conta do risco comercial mais alto. Para tanto, o programa criou um projeto paralelo, chamado Cinema da Cidade, que prevê a aplicação de recursos do orçamento da União, por meio de convênios com prefeituras e governos estaduais, na implantação de cinemas de propriedade pública em cidades do Grupo 1 que não disponham desse serviço.

\footnotetext{
${ }^{6} \mathrm{O}$ programa adota estratificação de classes sociais do IBGE, que define as classes de acordo com a renda familiar. A classe $\mathrm{C}$ compreende as famílias com renda de 4 a 7 salários mínimos e representam, na formulação do Cinema Perto de Você, um nova camada de público potencial.
} 


\section{Quadro 4 - Grupos de prioridade do Cinema Perto de Você}

\begin{tabular}{|l|l|}
\hline GRUPO 1 & $\begin{array}{l}\text { municípios com mais de } 20 \text { mil e menos de } 100 \text { mil habitantes que não possuem } \\
\text { salas de cinema. }\end{array}$ \\
\hline GRUPO 2 & $\begin{array}{l}\text { cidades com mais de } 100 \text { mil habitantes que não possuem salas de cinema. É o } \\
\text { grupo de mais alta prioridade para a linha financeira. Os grupos } 1 \text { e } 2 \text { usufruem das } \\
\text { taxas de juros mais baixas para os empréstimos e da maior porcentagem permitida } \\
\text { para a linha de investimento (50\%). }\end{array}$ \\
\hline GRUPO 3 & $\begin{array}{l}\text { cidades com mais de } 100 \text { mil e menos de } 500 \text { mil habitantes que possuem salas de } \\
\text { cinema. Este grupo apresenta dois perfis de empréstimo e investimento possíveis, } \\
\text { conferindo melhores taxas e aporte de investimento aos municípios cujo índice de } \\
\text { habitantes por sala seja maior que } 50 \text { mil. }\end{array}$ \\
\hline GRUPO 4 & $\begin{array}{l}\text { cidades com mais de } 500 \text { mil habitantes que possuem salas de cinema. São os 38 } \\
\text { maiores municípios do país. Nessas cidades, estão excluídas as zonas urbanas em } \\
\text { que a renda média dos chefes de família é muito baixa ou muito alta, ou seja, } \\
\text { podem participar as zonas com predominância de classe C. }\end{array}$ \\
\hline
\end{tabular}

Fonte: www.cinemapertodevoce.ancine.gov.br

Além de empréstimo e investimento voltados para a construção de salas, o Cinema Perto de Você prevê ações de estímulo à digitalização do parque exibidor, desoneração tributária no setor e implantação de um sistema de controle de bilheteria mais eficaz. $\mathrm{Na}$ atual conjuntura do mercado de distribuição cinematográfica, a digitalização da projeção é fator fundamental para uma política de inclusão no mercado audiovisual que contribua para uma expansão sustentável do parque exibidor, por conta da redução de custos e da potencial eliminação das barreiras para a distribuição física dos filmes. A digitalização torna-se um imperativo para a manutenção dos exibidores no mercado, porém o alto custo da importação de projetores digitais dificulta a modernização das empresas financeiramente mais vulneráveis. Nesse sentido, o FSA apresenta uma linha de crédito voltada para a digitalização.

Do ponto de vista da desoneração tributária, na tentativa de proporcionar condições de sustentabilidade para os empreendimentos dirigidos para a classe $\mathrm{C}$ ou localizados em cidades do interior, além de incentivar preços de ingressos mais acessíveis para a população, foi formulado um conjunto de ações voltadas tanto à desoneração dos investimentos, quanto à operação das novas salas. Por meio da Lei 12.599/2012, foi instituído o Regime Especial de Tributação para o Desenvolvimento da Atividade de Exibição Cinematográfica (Recine), que suspende todos os tributos federais incidentes sobre a aquisição de máquinas, aparelhos, instrumentos, equipamentos e materiais necessários à construção ou modernização de complexos cinematográficos. Para 
usufruírem desse benefício, empresas exibidoras, construtoras, incorporadoras e locadoras de equipamentos para salas de cinema devem credenciar previamente seus projetos na Ancine. Já no âmbito do Projeto Cinema na Cidade, são exigidos dos municípios e governos estaduais compromissos de redução de tributos na operação das salas.

Até meados de 2014, o Cinema Perto de Você havia beneficiado, pela linha de crédito e investimento, a construção de 29 novos complexos, totalizando 163 salas. Outros 40 novos complexos receberam incentivo do Recine. Cerca de 25 exibidores foram beneficiados para a modernização e/ou ampliação de 157 complexos, metade deles administrada pelas empresas internacionais Cinemark (EUA) e Cinépolis (México). No próximo capítulo, veremos mais detalhadamente como o programa foi formulado e implementado, em que medidas os seus objetivos e metas foram atingidos, como o público percebeu a chegada das novas salas e quais barreiras e limitações ainda se apresentam para a concretização da ampliação do acesso ao cinema no Brasil. 


\section{A ATUaÇÃo do CINEMA PeRTo de VOCÊ NO ACESSO E A HEGEMONIA DO CINEMA COMERCIAL}

A partir dos fundamentos epistemológicos da Economia Política da Comunicação apresentados por Mosco (1996, p.137), este capítulo analisa a implementação do Cinema Perto de Você sob uma perspectiva realista, inclusiva, constitutiva e crítica, e adota os conceitos de mercantilização, espacialização e estruturação como chaves analíticas do contexto amplo em que se insere o programa, além dos conceitos de acesso material e acesso cultural e simbólico como instrumentos adicionais para avaliar de que formas o CPV interfere no acesso da população ao cinema.

$\mathrm{Na}$ tentativa de encarar o objeto de forma "realista", conforme definido pela EPC, nos propusemos a combinar a análise de dados com a observação empírica da concretização do programa. Assumindo uma postura crítica, que compara diferentes visões sobre a formulação, implementação e resultados alcançados, e enxergando os instrumentos de análise não como unidades independentes ou lineares, mas como processos e categorias mutuamente constitutivas, pretendemos ir além de uma avaliação categórica do programa e oferecer uma análise que leve em conta a complexidade e dinamicidade do contexto econômico, político, social e cultural do qual faz parte. Ainda, ao entender que a EPC adota uma postura epistemológica inclusiva, recorremos a autores de outras áreas de conhecimento para auxiliar na construção de um conceito de acesso mais consistente e adequado a este estudo.

Orientando a interpretação dos dados e observações recolhidas a partir do que Mosco chama de "processos de entrada" e evitando tratar as estruturas e instituições como elementos estanques ou deterministas, analisaremos como a mercantilização, a espacialização e a estruturação permeiam as concepções subjacentes ao Cinema Perto de Você, de que maneiras esses processos se materializam na implementação do programa e quais as suas consequências.

Conectada com essa abordagem epistemológica, está uma ontologia que traz para o primeiro plano a mudança social, o processo social e as relações sociais em oposição à tendência na pesquisa social, especialmente a economia política, de se concentrar na estrutura e nas instituições. Isso significa que a pesquisa parte da perspectiva de que a mudança social é onipresente, que estruturas e instituições estão no constante processo de mudança, e que é mais útil desenvolver pontos de entrada que caracterizem processos do que nomear 
instituições [...]. Colocar em primeiro plano a mudança social a partir desses processos não substitui estruturas e instituições, o que seria substituir uma forma de essencialismo por outra. Ao invés disso, esses são pontos de entrada que constituem uma teoria substantiva da economia política, uma escolha preferível entre um leque de possíveis meios de entender o campo social. (MOSCO, 1996, p.138, tradução nossa)

A mercantilização é definida como o processo de transformar as coisas valorizadas por seu uso em produtos comercializáveis caracterizados por seu valor de troca. No âmbito da comunicação, a EPC analisa como o ato de comunicação torna-se um produto voltado para o lucro. Tradicionalmente, os economistas políticos tenderam a pensar a comunicação em forma de mercadoria a partir do conteúdo midiático, ou seja, o processo de mercantilização na comunicação envolveria a transformação de mensagens em produtos comercializáveis: "Como resultado, a comunicação é tomada como uma mercadoria especial e particularmente poderosa porque, além da sua habilidade de produzir mais valia, ela contém símbolos e imagens cujo significado ajuda a moldar a consciência" (MOSCO, 2009, p.134, tradução nossa). Mosco ressalta, entretanto, que não se trata de considerar a mídia de massa como uma instância instrumental ou autônoma, mas de perceber que ela está totalmente integrada com o processo de produção hegemônico. Para além do esforço de definir o que seria a mercadoria na mídia, é mais significativo entender como o processo de mercantilização interfere na produção, distribuição e troca de conteúdos.

O termo espacialização foi introduzido pelo teórico social Henri Lefebvre para designar o processo de superação dos limites de espaço e tempo na vida social. Mais do que aniquilar o espaço através do tempo, como sugeriu Marx, o capital transforma o espaço, ao reestruturar as relações espaciais entre pessoas, bens e mensagens, reestruturando a si mesmo nesse processo (MOSCO, 2009, p.157). Na comunicação, a espacialização refere-se mais especificamente ao processo pelo qual a mídia de massa e as tecnologias da comunicação ultrapassam os limites do espaço geográfico para organizar negócios em nível mundial, o que lhes permite alcançar maior acesso aos consumidores, trabalhadores, tecnologia e capital, interferir na configuração de diversos tipos de concentração empresarial, criar novas redes hierárquicas e reforçar antigas desigualdades econômicas e sociais. O termo espacialização difere de globalização porque tenta afastar as visões utópicas, comumente atreladas a este último, de um mundo homogêneo, de uma sociedade em rede: "Falar de uma sociedade em rede é um constructo ideológico que 
obscurece as relações capitalistas e as desigualdades estruturais que modelam a sociedade contemporânea" (MOSCO, 2009, p.180).

Já a estruturação descreve o processo pelo qual as estruturas são constituídas pela ação humana, ao mesmo tempo que moldam os meios desta constituição: "A vida social é composta da mútua constituição da estrutura e da ação; em poucas palavras, a sociedade e o indivíduo criam um ao outro. Somos o produto de estruturas que nossa ação social produz" (MOSCO, 2009, p.185, tradução nossa). A estruturação equilibra a tendência na Economia Política de destacar as estruturas, tipicamente as instituições governamentais e empresariais, ao incorporar as ideias de ação, relação social, processo social e prática social. Ao mesmo tempo, rejeita a noção extrema de analisar a ação na ausência de estruturas, porque são as estruturas que oferecem os meios pelos quais a ação opera. Mosco afirma que, tradicionalmente, a Economia Política da Comunicação deu mais atenção à classe social, tanto como relação social quanto como instrumento de análise, no estudo da ação e da prática social, por conta da sua centralidade no processo de estruturação. Porém, ele também aponta que há outras dimensões que se complementam e se chocam com a análise da classe social, incluindo gênero, raça e movimentos sociais. ${ }^{7}$ Em última instância, trata-se de colocar as relações de poder no centro da análise e examinar como o poder opera para cristalizar o senso comum em hegemonia:

\footnotetext{
O objetivo é ir além da noção de que estas são simplesmente categorias sobre as quais a mídia tem impacto. A proposta é examiná-las como meios de descrever as relações sociais das práticas de comunicação, inclusive como elas servem para organizar a ação dos indivíduos que as produzem. (MOSCO, 2009, p.189, tradução nossa)
}

Do âmbito do estudo do acesso, embora alguns autores que pesquisam e discutem as políticas culturais tenham levantado a necessidade do aprimoramento desse conceito utilizado acadêmica e institucionalmente, ainda carecemos de uma revisão e sistematização mais densa nesse sentido. Na área da saúde, a discussão do conceito de acesso em torno das práticas e dos serviços de saúde é mais antiga e possui semelhanças e afinidades com a perspectiva de acesso ao cinema aqui proposta, guardadas as devidas especificidades.

\footnotetext{
${ }^{7}$ No caso específico da análise do Cinema Perto de Você, a dimensão da classe social é a que mais nos interessa. Um estudo que leve em consideração uma análise do conteúdo dos filmes pode aprofundar as dimensões de raça e gênero e avaliar de que formas elas reforçam ou contestam outros tipos de relações de poder.
} 
Landini, Cowes e D'amore (2014, p.232) apontam que, embora os conceitos de acesso e acessibilidade apareçam em diversos trabalhos científicos e documentos institucionais das políticas de saúde, especialmente aqueles voltados para a atenção primária, muitas vezes ele é utilizado de forma imprecisa ou com profundidade conceitual limitada. Partindo de uma ampla revisão bibliográfica, os autores propõem uma discussão crítica da noção de acessibilidade, entendida como a articulação ou ajuste entre as características da oferta e as características e necessidades da demanda, ou seja, a capacidade de transpor as barreiras que existem entre uma e outra, o que permite acessar o serviço satisfatoriamente.

Para os autores, é comum perceber as barreiras prioritariamente pelos seus aspectos geográficos e financeiros, porém eles ressaltam que a dimensão cultural é igualmente relevante. A ênfase na oferta e na disponibilidade geográfica muitas vezes leva a responsabilizar demasiadamente o usuário pela concretização do acesso, uma vez que é ele quem se desloca até o serviço, ignorando a capacidade ativa do sistema de superar conflitos culturais que afastam o usuário. Eles delimitam, dessa forma, duas grandes correntes de tipologias do acesso.

A primeira corrente diferencia disponibilidade (existência do serviço em um determinado território), acessibilidade (se as pessoas possuem os meios necessários para utilizá-los, especialmente no que se refere à localização em relação à moradia) e aceitabilidade (se os serviços respondem às necessidades, expectativas e valores dos usuários, incentivando a continuidade) (LANDINI; COWES; D’AMORE, 2014, p.233). A segunda corrente diferencia dimensões do acesso, normalmente divididas entre geográfica (distância entre os beneficiários e os serviços, e a possibilidade de cumprir os trajetos pelos meios de transporte disponíveis), econômica (capacidade financeira das pessoas em relação ao custo do deslocamento, do serviço, dos medicamentos etc), administrativa (refere-se aos entraves burocráticos do serviço, como horários e dias de funcionamento das unidades de saúde) e cultural (focada nos hábitos e costumes da população e nas diferenças existentes entre o nível cultural dos profissionais e da organização do serviço, por um lado, e dos beneficiários, por outro). À dimensão cultural, Stolkiner e sua equipe (apud LANDINI; COWES; D’AMORE, 2014, p.234) adicionam uma dimensão simbólica, destacando que os imaginários sociais e as representações dos sujeitos também podem se constituir em barreiras específicas que devem ser levadas em conta. Mesmo na área da 
saúde, portanto, é recente o estudos das crenças, valores, atitudes e preferências dos usuários e seu impacto na atenção recebida.

Por conta da pertinência de abordagem em relação aos dados levantados nesta pesquisa, além do marco teórico-metodológico da Economia Política da Comunicação, utilizaremos esse quadro de dimensões para o aprofundamento da análise, adaptando-o para a discussão do acesso ao cinema nacional. A dimensão geográfica caracteriza-se pela existência de salas de cinema em local que possa ser acessado pelo público pelos meios de transporte disponíveis. A dimensão econômica refere-se à capacidade financeira do espectador de arcar com os custos de transporte, estacionamento, ingressos, lanches e outros custos associados. Do ponto de vista administrativo, podemos ressaltar as facilidades ou entraves da distribuição dos filmes nos dias e horários disponíveis, as promoções ofertadas, a diversidade da forma de pagamento e a estrutura física de cada estabelecimento. Finalmente, a dimensão cultural e simbólica relaciona-se aos costumes e hábitos de consumo audiovisual dos espectadores, bem como às aproximações e distanciamentos possíveis entre seus repertórios e os dos filmes. Neste caso, a dimensão simbólica torna-se ainda mais relevante, pois mobiliza imaginários e representações não apenas no ato de ir ao cinema, como também na fruição dos filmes.

Mesmo entendendo que todas essas dimensões são mutuamente constitutivas, pelas características e imbricações das dimensões geográfica, econômica e administrativa, convém agrupá-las em um único eixo de análise, aqui chamado de acesso material. Já os reflexos dos processos de mercantilização, a espacialização e a estruturação serão analisados tanto na dimensão material do acesso, quanto na dimensão cultural e simbólica.

\subsection{Acesso material e a hegemonia do modelo de exibição multiplex}

O momento em que o país teve o maior número de salas de cinema, distribuídas pelo maior número de municípios, foi a década de 1970, quando se atingiu a marca de 3.276 salas. O modelo de exibição era de grandes cineteatros de rua, com capacidade de até 1.500 poltronas, espalhados por diversos bairros dos grandes centros urbanos e por inúmeras cidades do interior do país. No final dos anos 1980 e início dos anos 1990, não foi apenas a produção nacional que sentiu os reflexos da crise econômica. Segundo Autran 
(2009, p.124), o setor exibidor também entrou em crise "devido, entre outros fatores: à falta de uma política governamental, ao empobrecimento da população em decorrência da inflação, à concorrência com a programação da televisão, à especulação imobiliária e à degradação urbana associada à violência nos grandes centros”. Em 1990, já tínhamos menos da metade das salas, chegando ao pior número em 1995, com 1.033 salas registradas.

Até então, a exibição era uma atividade majoritariamente exercida por empresas nacionais. A partir de 1998, com a chegada de grupos transnacionais como Cinemark e UCI, o setor voltou a crescer paulatinamente, porém sob o modelo de negócio dos multiplexes. Enquanto as grandes salas de rua continuavam a fechar, complexos de salas menores eram abertos em shoppings, oferecendo o que havia de mais moderno em termos de tecnologia de projeção. Conforme demonstram Autran (2009) e Gatti (2008), o novo modelo de exibição acarretou a concentração das salas nas capitais e grandes cidades, a elevação do preço dos ingressos e a elitização do público e, apesar de um maior número de salas no mesmo complexo e da possibilidade de estrear vários filmes simultaneamente, eles consideram que se criou uma tendência à homogeneização da programação.

Esta nova conjuntura reflete o avanço da espacialização, ou seja, do conjunto de processos e relações derivados da eliminação das barreiras geográficas pela mídia de massa e pelas tecnologias da comunicação. Atrelado à transcendência dos limites geográficos, Mosco (2009, p.158) destaca, como consequências da espacialização, a expansão de variados tipos de concentração empresarial, o controle sobre a produção, distribuição e troca de comunicação e a limitação da concorrência e da diversidade de informação e entretenimento disponíveis na sociedade. A história do cinema é marcada pela disputa dos mercados internacionais, protagonizada pelos Estados Unidos, mas o processo de espacialização em curso nas últimas décadas potencializou a concentração do controle sobre o mercado cinematográfico mundial nas mãos de um pequeno grupo de conglomerados de mídia transnacionais.

A eficiência das corporações depende das tecnologias de comunicação e informação, bem como dos sistemas de transporte, porque eles permitem o gerenciamento das ferramentas de controle de velocidade e formas de integração. Ao adotar diversos tipos de concentração e fusão, essas empresas controlam toda a cadeia de produção, inclusive o desenvolvimento de softwares e hardwares empregados no setor, e aproveitam-se de um 
outro braço da espacialização, a divisão internacional do trabalho, que lhes permite transcender os limites culturais, legais, regulatórios e financeiros de suas bases e lhes garante uma redução considerável dos custos. Por meio desse oligopólio, os conglomerados asseguram a eficiência máxima da veiculação dos seus produtos audiovisuais e, consequentemente, limitam a diversidade de produtores, distribuidores e exibidores independentes, que não conseguem se inserir no mercado de maneira equânime.

No final dos anos 1990, quando a retomada possibilitada pelas leis de incentivo demonstrou que o aumento da produção por si só não atraiu de volta o público dos filmes nacionais, a discussão quanto a medidas de fomento à difusão e ao acesso voltou à pauta. Analisando os posicionamentos de diversos atores do setor, como o produtor Luiz Carlos Barreto e os cineastas e gestores públicos Orlando Senna e Gustavo Dahl, Autran (2009) aponta que houve, no início dos anos 2000, um certo consenso em torno da ideia de que o novo modelo de exibição complexificou a questão do público, não apenas por conta do aumento do preço do ingresso ou da aparente dominação de um padrão estético, mas porque criou um novo padrão de consumo que afastou as camadas mais populares do cinema. Medidas como o subsídio para os exibidores que projetassem filmes nacionais e a criação de uma rede de salas mais descentralizada e com preços populares estavam entre as ideias mais discutidas:

\footnotetext{
Esse tipo de solução tinha a reforçá-la tanto o desempenho geral muito fraco dos filmes nacionais nos multiplexes quanto o fato de que alguns grandes sucessos brasileiros de público dos últimos anos como Carandiru (Hector Babenco, 2003) ou Maria, mãe do filho de Deus (Moacyr Góes, 2003) tiveram boa parte das suas receitas obtidas em cinemas de rua ou em salas localizadas em shoppings com forte afluência da classe média baixa. (AUTRAN, 2009, p.129).
}

Encarando a mercantilização a partir da definição de Mosco (2009, p.132), ou seja, como a transformação de valores de uso - ligados a um amplo leque de necessidades individuais e coletivas, tanto físicas quanto culturais - em valores de troca, definidos pelo seu potencial de comercialização no mercado, podemos analisar como esse processo repercute não apenas no modo hegemônico de produção, distribuição e exibição do cinema, mas também na formulação e implementação das políticas culturais do setor. $\mathrm{O}$ autor defende que é preciso desconstruir a mercadoria para desvendar as relações sociais e o sistema de produção subjacentes e ressalta duas grandes dimensões da mercantilização na comunicação: por um lado, os processos e tecnologias da comunicação contribuem para 
a mercantilização na sociedade como um todo; por outro, o processo geral de mercantilização penetra os processos e instituições de comunicação e influenciam a comunicação enquanto prática social.

A mercantilização faz com que atividades de comunicação que poderiam ter compromisso social com o acesso universal, além de conteúdos que refletissem diversidade, transformem-se em uma comunicação comercial que oferta acesso apenas a quem pode pagar e conteúdos que cumprem com os interesses dos anunciantes. A naturalização da mercantilização, por sua vez, obscurece as contradições das relações sociais e econômicas que existem por trás da mercadoria, como se não fossem resultado da correlação de forças hegemônicas sobre a produção e distribuição. No caso do cinema, que desde seus primórdios apresentou-se como uma tecnologia e uma forma de expressão voltadas para a comercialização e para o consumo, torna-se ainda mais difícil detectar o potencial de seu valor de uso para além do seu valor de troca. A hegemonia adquirida pelo modelo de produção em massa dos grandes estúdios - no caso brasileiro, da Globo Filmes -, pela distribuição das majors $^{8}$ e pela exibição do formato multiplex em shoppings naturaliza esses padrões como os únicos verdadeiramente viáveis e subjuga tentativas de inversão dessa lógica:

\begin{abstract}
O processo [de mercantilização] reduz as fontes, o tempo e o espaço disponível para alternativas, de modo que a mercantilização é percebida não como um processo de poder, mas como uma realidade da vida social de ordem natural, de senso comum, tomada como certa. [...]. O poder institucional, promovendo uma lógica e eliminando alternativas, é fundamental para a construção da hegemonia. Mas há também a questão da ligação entre o poder institucional e o poder que atua sobre a relação multidimensional entre valor de uso e valor de troca. $\mathrm{O}$ valor de troca se expande não só minando o valor de uso, mas também pela utilização desses valores para se tornar mais atrativo e, no processo, transformar estes usos em valor de troca. (MOSCO, 1996, p.145, tradução nossa)
\end{abstract}

Apesar de alguns programas do Ministério da Cultura como a Programadora Brasil, Cine+Cultura e Pontos de Difusão atuarem no sentido de facilitar e difundir o acesso ao cinema e de os artigos $1^{\circ}$ e $1^{\circ} \mathrm{A}$ da Lei do Audiovisual preverem o credenciamento de projetos específicos de distribuição, difusão, preservação, exibição e infraestrutura técnica, foi somente em 2011, com recursos viabilizados pelo FSA, que se sistematizou uma série

\footnotetext{
8 IKEDA (2011, p.60) define major como "um oligopólio global que corresponde aos 'filmes hollywoodianos', originalmente produzidos pelos estúdios, mas cuja produção atual tornou-se mais complexa e dinâmica, conforme os rumos de um capitalismo contemporâneo, num processo de mundialização dos fluxos financeiros e da formação de grandes conglomerados universais".
} 
de ações coordenadas para o setor de exibição comercial, reunidas no programa Cinema Perto de Você. Ao estabelecer como objetivos (1) a expansão e descentralização do parque exibidor de cinema; (2) a facilitação do acesso da população por meio da abertura de salas em cidades de médio porte e em bairros populares das grandes cidades; e (3) a ampliação do estrato social de frequentadores de salas de cinema, com atenção especial para os novos consumidores da classe $\mathrm{C}$, é possível perceber a preponderância da dimensão material do acesso na formulação da política. As linhas de ação traçadas para alcançar esses objetivos foram: crédito e investimento para a construção de novos cinemas nas cidades e bairros que se enquadram no perfil de prioridade do programa, desoneração tributária de equipamentos e serviços para a construção e modernização/digitalização das salas, e aprimoramento do controle de bilheteria, o que permite dados mais precisos para o acompanhamento de mercado e, assim, para a avaliação e adequação da política.

A partir das informações contidas no Informe Anual de Acompanhamento de Mercado da Ancine, referente ao ano de 2013, é possível avaliar em que medida as metas do Cinema Perto de Você estão sendo atingidas. A meta de digitalização foi a única já alcançada durante os dois primeiros anos de pleno funcionamento do programa. A abertura de novas salas e a meta de que todos os municípios com mais de 100 mil habitantes tenham cinema apresentaram níveis de execução satisfatórios para o curto período em questão. A diminuição do índice de habitantes por sala e o crescimento da venda de ingressos, contudo, ainda não atingiram nem metade do percentual estabelecido, conforme podemos observar no Quadro 5:

\section{Quadro 5 - Alcance das metas do Cinema Perto de Você}

\begin{tabular}{|l|l|}
\hline \multicolumn{1}{|c|}{ META ESTABELECIDA } & \multicolumn{1}{c|}{ SITUAÇÃO EM 2013 } \\
\hline $\begin{array}{l}\text { Nenhum município com mais de } 100 \\
\text { mil habitantes sem sala. }\end{array}$ & $\begin{array}{l}\text { Até 2013, cerca de 72,5\% dos municípios com mais de 100 mil } \\
\text { habitantes possuíam salas de cinema. Todas as cidades } \\
\text { brasileiras com mais de 500 mil habitantes são atendidas e 54\% } \\
\text { das novas salas abertas a partir de 2010 estão localizadas em } \\
\text { cidades com população entre 100 mil e 500 mil habitantes. }\end{array}$ \\
\hline $\begin{array}{l}\text { Média nacional de } 60 \text { mil habitantes por } \\
\text { sala, queda de 30\% do índice em 2011. }\end{array}$ & $\begin{array}{l}\text { Média nacional de 75 mil habitantes por sala. Queda de 12\% do } \\
\text { índice verificado em 2011, quando o programa foi lançado. }\end{array}$ \\
\hline $\begin{array}{l}\text { Crescimento de 30\% na venda de } \\
\text { ingressos. }\end{array}$ & Crescimento de 10,8\% na venda de ingressos em relação a 2010. \\
\hline $\begin{array}{l}\text { Digitalização de metade das salas de } \\
\text { cinema do país. }\end{array}$ & $\begin{array}{l}\text { No final de 2013, exatos 50\% das salas já possuíam projeção } \\
\text { digital, sendo mais da metade delas 3D. }\end{array}$ \\
\hline $\begin{array}{l}\text { Abertura de } 600 \text { novas salas de cinema } \\
\text { com base nos recursos do programa. }\end{array}$ & $\begin{array}{l}\text { Dados reunidos pela pesquisa até julho de 2014 demonstram que } \\
\text { 461 novas salas foram contempladas com recursos do CPV. }\end{array}$ \\
\hline
\end{tabular}

Fontes: www.cinemapertodevoce.ancine.gov.br/objetivos-e-metas e Informe Anual de Acompanhamento de Mercado 2013 - Exibição. 
Quanto à expansão e descentralização do parque exibidor, é possível constatar que o programa influencia positivamente a abertura e modernização das salas, contribuindo para a manutenção de uma média de crescimento entre 4\% e 7\% desde 2010, porém não conseguiu, até o momento, interferir significativamente na concentração regional. $O$ Quadro 6 demonstra que, embora os maiores índices de crescimento desde 2010 tenham ocorrido nas regiões Norte e Nordeste, a distribuição das salas permanece praticamente inalterada, pois as regiões Sul e Sudeste continuam com mais de 70\% das salas do país:

\section{Quadro 6 - Salas de exibição por região (2010 a 2014)}

\begin{tabular}{|c|c|c|c|c|c|c|c|c|c|c|c|}
\hline \multirow{2}{*}{ Região } & $\mathbf{2 0 1 0}$ & $\mathbf{\%}$ & $\mathbf{2 0 1 1}$ & $\mathbf{\%}$ & $\mathbf{2 0 1 2}$ & $\mathbf{\%}$ & $\mathbf{2 0 1 3}$ & $\mathbf{\%}$ & $\mathbf{2 0 1 4}$ & $\mathbf{\%}$ & $\begin{array}{c}\text { Variação } \\
\mathbf{n y y y y y y y y y y y}\end{array}$ \\
\cline { 2 - 13 }$n$ & $\mathbf{2 0 1 0} / \mathbf{2 0 1 3}$ \\
\hline Centro-Oeste & 198 & 9 & 203 & 9 & 213 & 9 & 239 & 9 & 245 & 9 & $24 \%$ \\
\hline Nordeste & 270 & 12 & 284 & 12 & 307 & 12 & 351 & 13 & 403 & 14 & $49 \%$ \\
\hline Norte & 98 & 4 & 113 & 5 & 125 & 5 & 136 & 5 & 152 & 5 & $55 \%$ \\
\hline Sudeste & 1.270 & 58 & 1.353 & 57 & 1.440 & 57 & 1.497 & 56 & 1.574 & 56 & $24 \%$ \\
\hline Sul & 370 & 17 & 399 & 17 & 432 & 17 & 455 & 17 & 456 & 16 & $23 \%$ \\
\hline Total & $\mathbf{2 . 2 0 6}$ & & $\mathbf{2 . 3 5 2}$ & & $\mathbf{2 . 5 1 7}$ & & $\mathbf{2 . 6 7 8}$ & & $\mathbf{2 . 8 3 0}$ & & $\mathbf{2 8 \%}$ \\
\hline
\end{tabular}

Fontes: Informe Anual de Acompanhamento de Mercado 2013 e Informe Anual Preliminar 2014 (Ancine)

Ao final de 2014, foram registradas 2.830 salas no país, distribuídas em 747 complexos, em 407 cidades, que representam pouco mais de 7\% do total de municípios brasileiros. Cerca de 17,5\% das salas estão concentradas apenas nas capitais do Rio de Janeiro e São Paulo. O Quadro 7 apresenta a distribuição geográfica dos novos complexos em funcionamento ou a serem construídos com recursos do CPV. 
Quadro 7 - Distribuição geográfica de novos complexos beneficidados pelo CPV

\begin{tabular}{|c|c|c|c|c|c|}
\hline Cidade & Estado & Complexo/ Empresa & Salas & $\begin{array}{c}\text { Crédito/ } \\
\text { Investimento }\end{array}$ & RECINE \\
\hline Arapiraca & $\mathrm{AL}$ & Cinesystem Arapiraca & 6 & $\mathrm{x}$ & $\mathrm{x}$ \\
\hline Maceió & $\mathrm{AL}$ & Cinesystem Maceió & 9 & $\mathbf{x}$ & $\mathrm{x}$ \\
\hline Manaus & $\mathrm{AM}$ & Cinépolis Ponta Negra & 5 & & $\mathrm{x}$ \\
\hline Salvador & $\mathrm{BA}$ & UCI Shopping Barra & 8 & & $\mathrm{x}$ \\
\hline Fortaleza & $\mathrm{CE}$ & Cinépolis Riomar & 10 & & $\mathrm{x}$ \\
\hline Fortaleza & $\mathrm{CE}$ & Cinépolis North Shooping Jóquei & 5 & & $\mathrm{x}$ \\
\hline Fortaleza & $\mathrm{CE}$ & UCI Shopping Parangaba & 6 & & $\mathrm{x}$ \\
\hline Brasília & $\mathrm{DF}$ & Cineflix JK Shopping & 6 & & $\mathbf{x}$ \\
\hline Cariacica & ES & Cinépolis Moxuxuara & 5 & & $\mathrm{x}$ \\
\hline Vila Velha & ES & Cinemark Vila Velha & 8 & & $\mathrm{x}$ \\
\hline Vila Velha & ES & Cinesystem Vila Velha & 6 & $\mathrm{x}$ & $\mathrm{x}$ \\
\hline Goiânia & GO & Cinemark Águas Shopping & 7 & & $\mathrm{x}$ \\
\hline Imperatriz & MA & Cinesystem Imperial & 5 & $\mathrm{x}$ & $\mathrm{x}$ \\
\hline São Luís & $\mathrm{MA}$ & Kinoplex Shopping da Ilha & 8 & & $\mathrm{x}$ \\
\hline Belo Horizonte & MG & Cineart Minas Shopping & 6 & $\mathrm{x}$ & \\
\hline Belo Horizonte & MG & Cineart Ponteio & 4 & $\mathbf{x}$ & \\
\hline Betim & MG & Cineart Monte Carmo & 7 & & $\mathrm{x}$ \\
\hline Betim & MG & Cinemark Metropolitan Garden & 9 & & $\mathrm{x}$ \\
\hline Contagem & MG & Cinesystem Contagem & 10 & & $\mathrm{x}$ \\
\hline Uberaba & MG & Kinoplex & 6 & $\mathbf{x}$ & \\
\hline Uberlândia & MG & Kinoplex & 5 & $\mathrm{x}$ & \\
\hline Marabá & PA & Movie Cinemas Nova Marabá & 5 & & $\mathrm{x}$ \\
\hline João Pessoa & $\mathrm{PB}$ & Cinépolis Mangabeira & 5 & & $\mathrm{x}$ \\
\hline Teresina & PI & Cinépolis Rio Poti & 12 & & $\mathrm{x}$ \\
\hline Curitiba & $\mathrm{PR}$ & Cinépolis Pátio Label & 8 & & $\mathrm{x}$ \\
\hline Londrina & PR & Cinemark Boulevard & 7 & & $\mathrm{x}$ \\
\hline Londrina & $\mathrm{PR}$ & Cinesystem Norte Shopping & 6 & $\mathrm{x}$ & $\mathrm{x}$ \\
\hline Campos dos Goytacazes & RJ & Kinoplex & 5 & $\mathrm{x}$ & $\mathrm{x}$ \\
\hline \begin{tabular}{|l|} 
Duque de Caxias \\
\end{tabular} & RJ & Kinoplex & 5 & $\mathrm{x}$ & \\
\hline Itaboraí & RJ & Cinesystem Itaboraí Plaza & 10 & & $\mathrm{x}$ \\
\hline Rio de Janeiro & RJ & Cinemark Metropolitano & 7 & & \\
\hline Rio de Janeiro & RJ & Cinesystem Americas & 12 & & $\mathrm{x}$ \\
\hline Rio de Janeiro & RJ & Cinesystem Parque Sulacap & 12 & & $\mathrm{x}$ \\
\hline Rio de Janeiro & RJ & Kinoplex Madureira & 5 & & $\mathrm{x}$ \\
\hline Rio de Janeiro & $\mathrm{RJ}$ & Cinesystem Via Brasil & 6 & $\mathrm{x}$ & \\
\hline Rio de Janeiro & RJ & Cinesystem Carrefour Sulacap & 6 & $\mathrm{x}$ & \\
\hline Rio de Janeiro & RJ & Kinoplex Santa Cruz & 6 & $\mathrm{x}$ & \\
\hline São Gonçalo & RJ & Kinoplex Alcântara & 5 & $\mathrm{x}$ & \\
\hline São Gonçalo & RJ & Cinespaço Boulevard & 6 & $\mathrm{x}$ & \\
\hline Natal & $\mathrm{RN}$ & Cinépolis Natal Shopping & 6 & & $\mathrm{x}$ \\
\hline Natal & $\mathrm{RN}$ & Cinépolis Norte Shopping & 6 & & $\mathrm{x}$ \\
\hline Alvorada & RS & Kinoplex & 5 & $\mathrm{x}$ & \\
\hline Gravataí & $\mathrm{RS}$ & GNC Gravataí & 5 & $\mathbf{x}$ & $\mathrm{x}$ \\
\hline Pelotas & RS & Cineflix Pelotas & 5 & & $\mathrm{x}$ \\
\hline Porto Alegre & $\mathrm{RS}$ & Cinespaço Bourbon Wallig & 8 & $\mathrm{x}$ & \\
\hline Porto Alegre & RS & Cineart Serra Sul & 4 & $\mathrm{x}$ & \\
\hline Porto Alegre & $\mathrm{RS}$ & Kinoplex & 5 & $\mathrm{x}$ & \\
\hline Porto Alegre & $\mathrm{RS}$ & GNC Praia de Belas & 6 & $\mathrm{x}$ & \\
\hline Rio Grande & RS & Cinesystem Rio Grande & 4 & $\mathbf{x}$ & $\mathrm{x}$ \\
\hline Florianópolis & $\mathrm{SC}$ & Cinespaço Beiramar Shopping & 5 & $\mathrm{x}$ & \\
\hline Americana & SP & Kinoplex & 5 & $\mathrm{x}$ & \\
\hline Bauru & SP & Cinépolis Nações Bauru & 6 & & $\mathrm{x}$ \\
\hline Botucatu & SP & Cineflix Botucatu & 5 & & $x$ \\
\hline Cotia & SP & Cineart Square Open Mall & 7 & $\mathrm{x}$ & \\
\hline Guarulhos & SP & Cinépolis Parque Shopping Maia & 11 & & $x$ \\
\hline Hortolândia & SP & Cinesystem Hortolândia & 5 & $\mathrm{x}$ & \\
\hline Limeira & SP & Cineflix Nações & 6 & & $\mathrm{x}$ \\
\hline Mogi Guaçu & SP & Cineflix Buriti & 5 & & $\mathrm{x}$ \\
\hline Piracicaba & SP & Kinoplex & 6 & $\mathbf{x}$ & \\
\hline Ribeirão Preto & SP & Cinépolis Iguatemi & 6 & & $\mathrm{x}$ \\
\hline Santo André & SP & Cinemark Atrium & 7 & & $\mathrm{x}$ \\
\hline São Bernardo do Campo & SP & Cinemark Golden Square & 5 & & $\mathrm{x}$ \\
\hline São Bernardo do Campc & SP & Cinépolis São Bernardo Plaza & 8 & & $\mathrm{x}$ \\
\hline \begin{tabular}{|l|} 
São José do Rio Preto \\
\end{tabular} & SP & Cinépolis Iguatemi & 7 & & $\mathrm{x}$ \\
\hline São Paulo & SP & Cinemark Shopping Cidade & 6 & & $\mathrm{x}$ \\
\hline São Paulo & SP & Cinemark Lar Center & 3 & & $x$ \\
\hline São Paulo & SP & Cinemark Tietê Plaza & 7 & & $\mathrm{x}$ \\
\hline São Paulo & SP & Cinemark Nova 25 de Março & 9 & & $\mathrm{x}$ \\
\hline Sorocaba & SP & Kinoplex & 6 & $\mathrm{x}$ & \\
\hline Taubaté & SP & Cinemark Via Vale Garden & 6 & & $\mathrm{x}$ \\
\hline Votorantim & SP & Cinépolis Votorantim & 7 & & $\mathrm{x}$ \\
\hline TOTAL: $\quad 71$ & 18 & 10 & 461 & 29 & 48 \\
\hline
\end{tabular}

Fonte: Elaboração própria a partir de dados da Ancine 
Além destes 71 novos complexos, até meados de 2014, cerca de outros 160 também foram contemplados para modernização, totalizando um conjunto representativo de salas beneficiadas. $\mathrm{O}$ alcance do objetivo de descentralização, contudo, ainda se mostra bastante tímido, pois mais da metade dos novos complexos estão localizados em cidades com mais de 500 mil habitantes, sendo 77,5\% do total nas regiões Sul e Sudeste. Selmo Kaufmann (2014) ressalta que o programa funciona como um indutor da expansão do parque exibidor e que os locais onde são implementadas as salas, desde que atendam as prerrogativas, dependem do interesse das empresas. A significativa desoneração do custo de implementação das salas nos locais atendidos pelo programa facilita o interesse dos exibidores nessas praças, mas suas escolhas demonstram que o eixo sul-sudeste apresenta maior confiança na sustentabilidade do empreendimento, pela própria concentração populacional e econômica, e também revelam que o mercado nessas regiões ainda não está saturado.

Esta tendência também pôde ser constatada na pesquisa de campo. Entre as salas visitadas, o maior impacto de abertura do novo complexo verificou-se em Hortolândia, onde $87 \%$ dos entrevistados afirmaram que passaram a ir ao cinema com mais frequência, seguido do Rio de Janeiro, com 50\%. Como se trata do primeiro e único cinema da cidade, 90\% das pessoas em Hortolândia passaram a dar preferência a esta sala em detrimento daquelas as quais costumavam ir anteriormente. Já o Rio de Janeiro, cidade que apresenta uma maior oferta de cinemas, foi o local em que mais pessoas afirmaram que continuam dando preferência a outras salas (33\%). Em Imperatriz, apenas 37\% afirmaram que a nova sala interferiu positivamente no hábito de ir ao cinema, mas $87 \%$ disseram que preferem a nova sala em detrimento do outro cinema da cidade. 


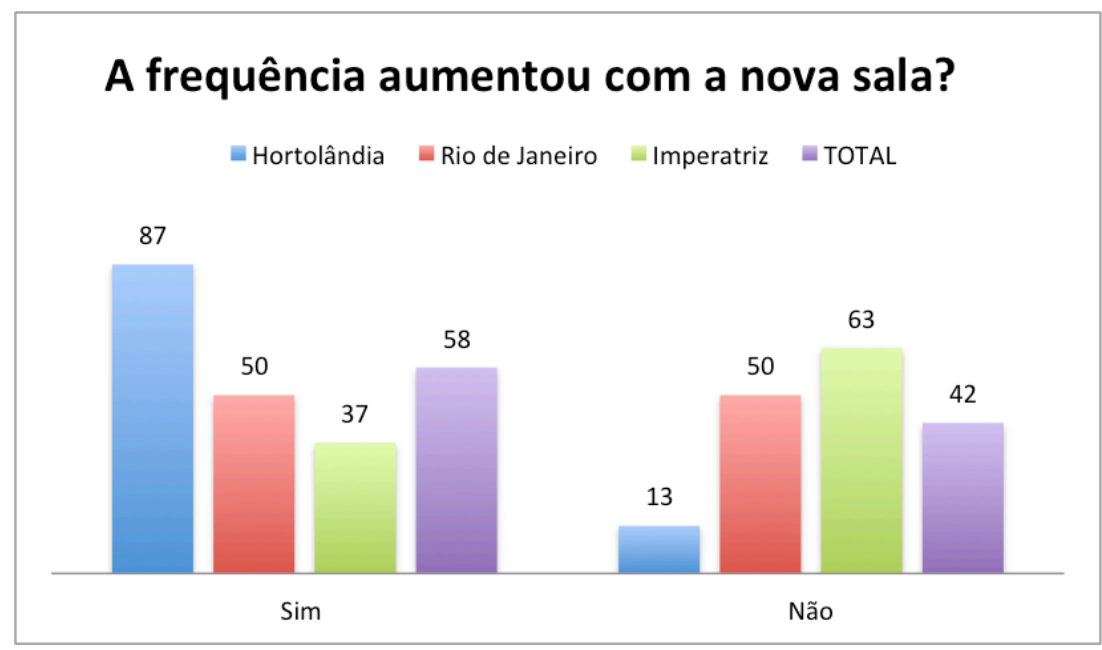

Gráfico 8 - A frequência aumentou com a nova sala? Fonte: Elaboração própria.

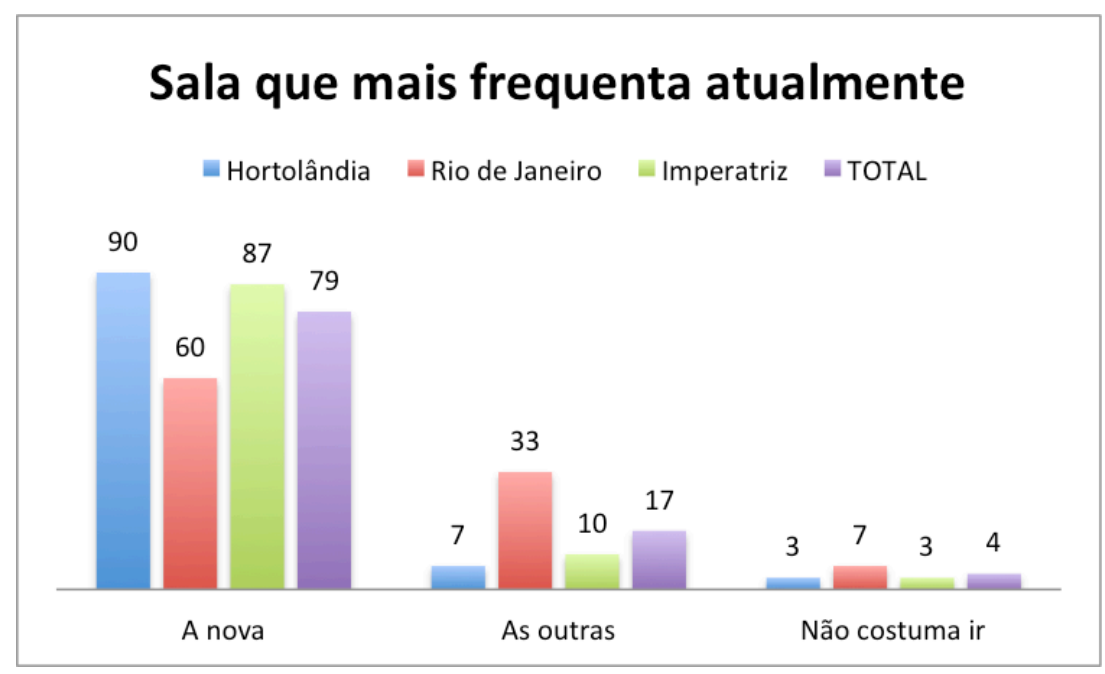

Gráfico 9 - Sala que mais frequenta atualmente. Fonte: Elaboração própria.

Além de um mercado aparentemente mais favorável, a diferença do aumento de frequência entre os entrevistados de Hortolândia e Imperatriz revela a importância das dimensões geográfica e econômica do acesso. O maior índice de proximidade entre a moradia e o cinema foi verificado em Hortolândia, onde 93\% dos entrevistados moram na mesma cidade ou bairro da sala, perto o suficiente para que um terço deles se desloque até o cinema a pé. Imperatriz apresentou o pior índice de proximidade: cerca de $33 \%$ dos entrevistados residem em cidade vizinhas, distantes de 30 a 126 quilômetros de Imperatriz, a única da região que possui cinema. Provavelmente por esse motivo, foi também a cidade em que os entrevistados mais mencionaram carro (67\%) e moto $(20 \%)$ como meios de 
transporte mais utilizados. Dessa forma, mesmo que exista uma grande oferta de cinemas em Campinas, cidade vizinha a Hortolândia, a grande maioria dos entrevistados prefere ir ao cinema mais próximo de casa e, por esse motivo, têm ido mais vezes, demonstrando que havia uma demanda na região e que a proximidade influencia diretamente na frequência. Já em Imperatriz, a distância geográfica ainda é uma barreira a ser vencida pelos moradores das cidades adjacentes, especialmente aqueles que não possuem veículo próprio para se deslocar.

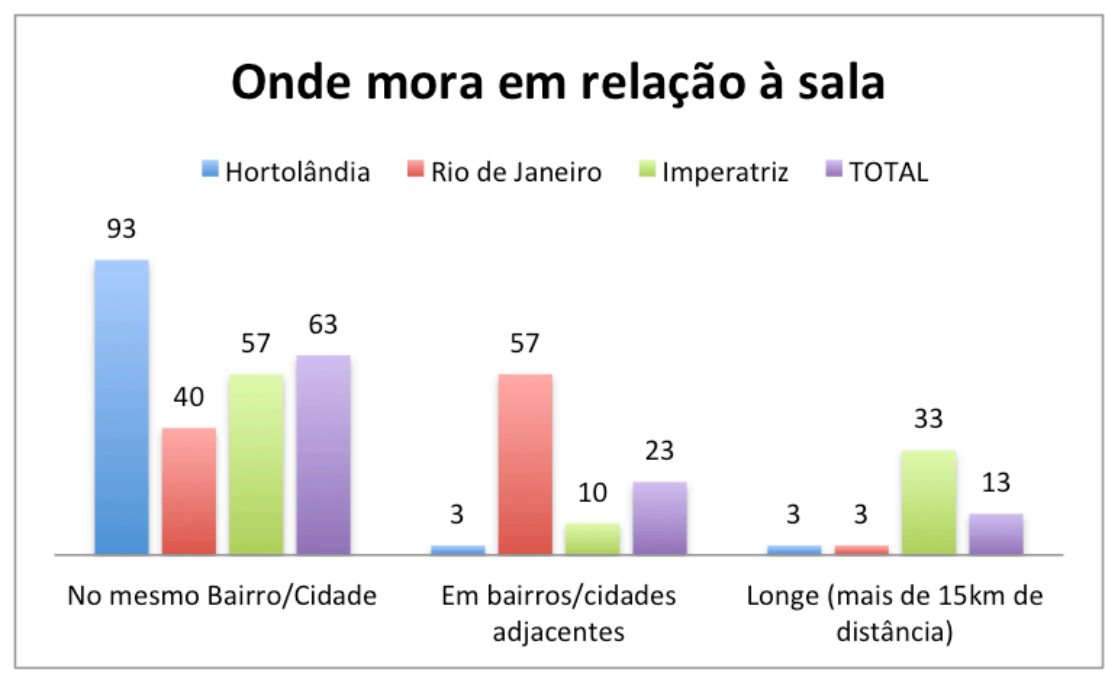

Gráfico 10 - Onde mora em relação à sala. Fonte: Elaboração própria.

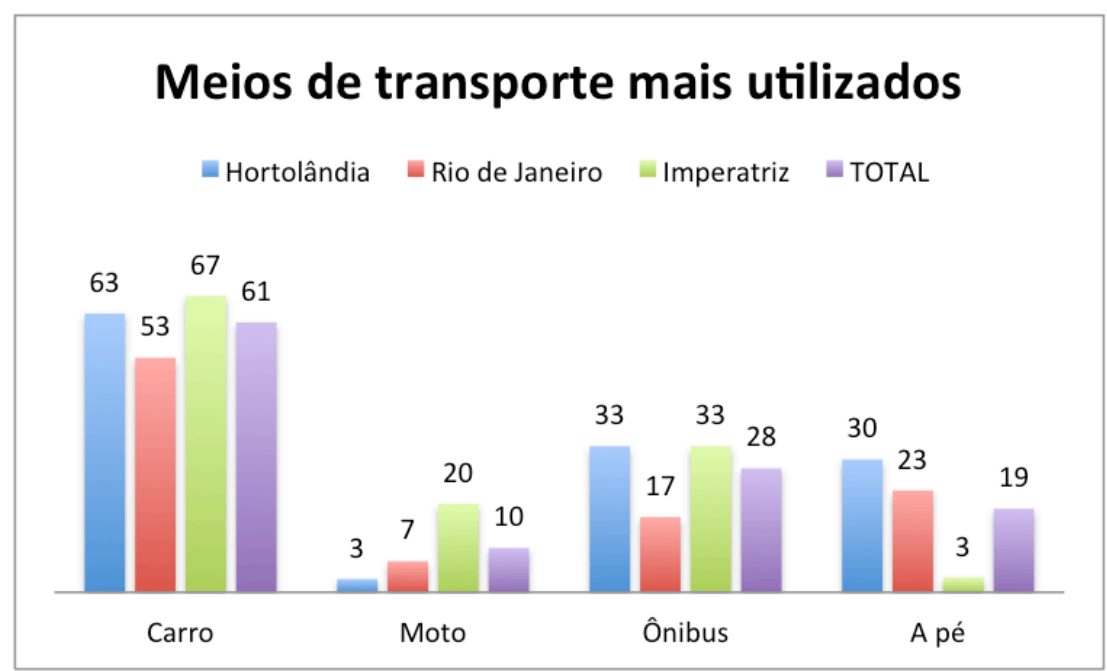

Gráfico 11 - Meios de transporte mais utilizados. Fonte: Elaboração própria. 
Do ponto de vista econômico, em Imperatriz, $50 \%$ das pessoas consideraram o valor dos ingressos caro e $67 \%$ afirmaram que iriam com mais frequência se o custo fosse menor, os maiores índices entre as três salas visitadas. A maior parte das pessoas em Hortolândia e no Rio de Janeiro (57\% e 53\%, respectivamente), também afirmou que iria ao cinema com mais frequência se os ingressos fossem mais baratos. Além disso, é relevante ressaltar que uma parte considerável das pessoas que avaliaram o valor do ingresso como barato justificou essa posição porque paga meia-entrada, seja por ser estudante ou idoso, seja porque dá preferência aos dias de promoção.

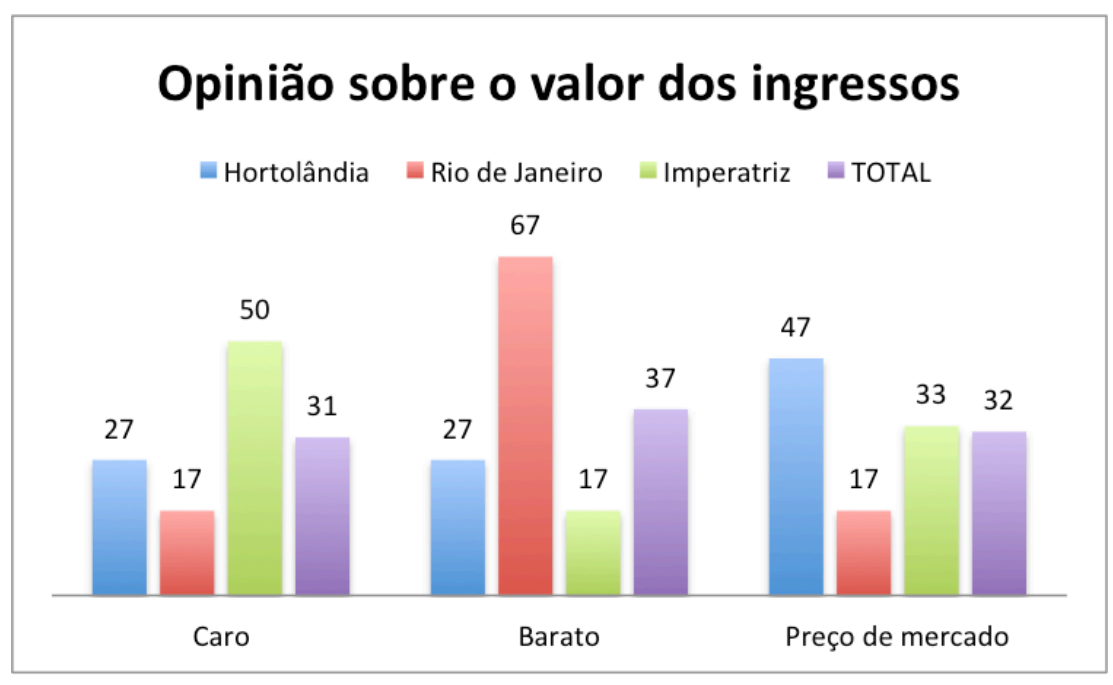

Gráfico 12 - Opinião sobre o valor dos ingressos. Fonte: Elaboração própria.

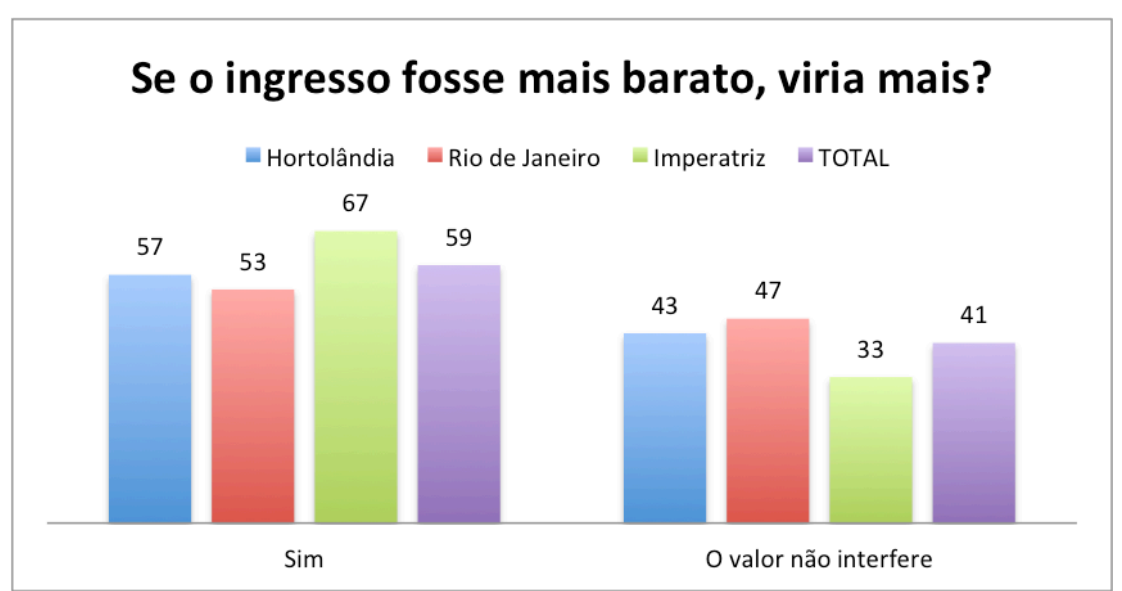

Gráfico 13 - Se o ingresso fosse mais barato, viria mais vezes? Fonte: Elaboração própria. 


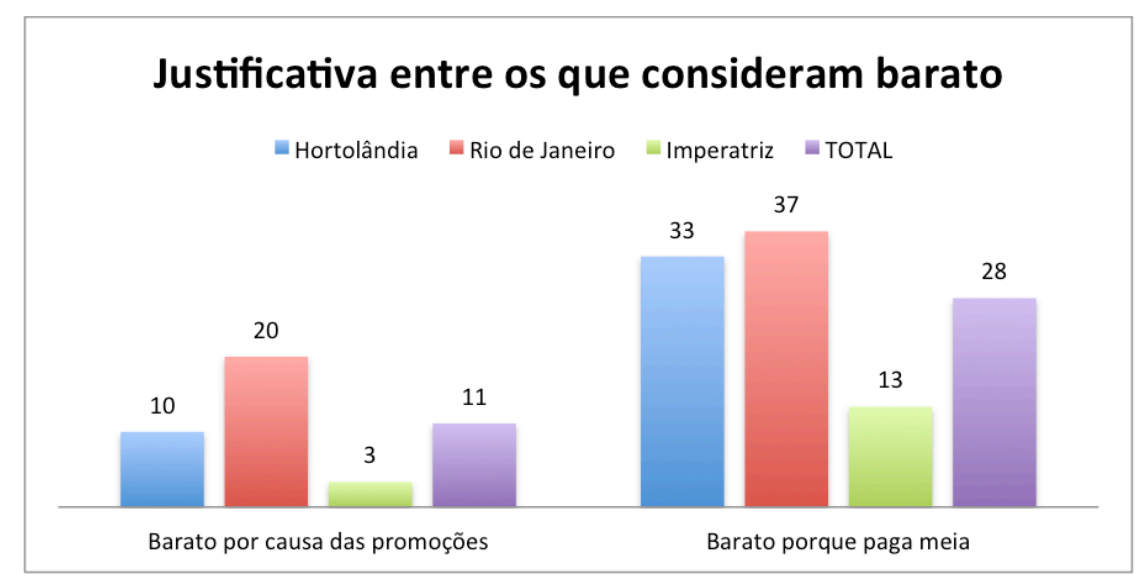

Gráfico 14 - Justificativas entre os que consideram o ingresso barato Fonte: Elaboração própria

É possível constatar, dessa forma, que o CPV, tal como foi formulado, tende a incentivar prioritariamente ${ }^{9}$ o modelo de exibição de multiplexes em shoppings e depende da expansão destes para concretizar a distribuição das salas pelo país. Além disso, como não prevê nenhuma contrapartida de barateamento dos ingressos nas salas contempladas, não consegue interferir significativamente no acesso financeiro dos espectadores. Segundo levantamento da Ancine, o preço médio do ingresso no Brasil, entre 2013 e 2014, foi de R\$ 12,15. Nas salas visitadas, o preço médio foi de $\mathrm{R} \$ 13,50$, demonstrando que está um pouco acima da média geral. Como aponta Barone, em relação aos entraves que esse padrão de exibição impõe atualmente,

\begin{abstract}
Não há perspectivas de grandes mudanças nesse quadro, por um conjunto de fatores de ordem econômica, política e também tecnológica. Há o alto custo de implantação e manutenção das salas de cinema no Brasil, todas em shoppings e nas grande cidades. O resultado é o ingresso caro, tornando o cinema inacessível à maioria da população. Um circuito com quatro mil salas, com maior abrangência geográfica, chegando ao interior do País, aumentaria também os custos de logística da operação de distribuição. Mais cópias, mais mídia, mais transporte e também mais publicidade. (BARONE, 2008, p.9)
\end{abstract}

A facilitação do crédito para novas salas, a desoneração tributária (que reduz em aproximadamente $30 \%$ o custo de implantação ou reforma) e o incentivo à digitalização (que diminui sensivelmente os custos de distribuição) podem estar contribuindo para a

\footnotetext{
${ }^{9}$ O Cinema da Cidade apresenta uma proposta de atuação diferente, mas a inexistência de salas beneficiadas por esse subprograma, até o momento de conclusão da pesquisa, impede uma avaliação adequada.
} 
ampliação do parque exibidor, mas o modelo de negócio ainda é caro e os incentivos não têm se mostrado eficazes no sentido de reduzir, por enquanto, o custo final para o espectador. Selmo Kaufmann (2014) afirma que, na formulação do programa, avaliou-se que uma interferência direta ou padronizada no valor dos ingressos, sem considerar as especificidades de cada local, poderia inibir as empresas ou comprometer a viabilidade econômica das salas. Ele defende que, à medida que o parque for crescendo, a concorrência tende a aumentar e, assim, isso obrigaria os exibidores a adotar medidas de atração do público, o que incluiria a redução de preços. O momento, no entanto, ainda seria de expansão e a concorrência não pode ser sentida.

O que se observa, entretanto, é que uma forte concorrência também tende a prejudicar os pequenos exibidores, que normalmente praticam ingressos mais baratos, porque os grandes conglomerados possuem maior capacidade de firmar parcerias e aplicar estratégias promocionais mais diversificadas. A rede Cinemark, por exemplo, em parceria com a empresa de telefonia Vivo, oferece $50 \%$ de desconto para os seus usuários. Correntistas do Banco Itaú usufruem do mesmo benefício nos cinemas das redes Kinoplex, UCI, Moviecom, Cineart, Playarte e Espaço Itaú de Cinema. Esse tipo de estratégia, contudo, atinge prioritariamente uma camada elitizada da população que já tinha mais acesso ao cinema. Aumentar demasiadamente a concorrência em um mercado que já é frágil e possui tão poucos agentes, sem a inclusão de novos estratos de espectadores, pode ter o efeito inverso ao preconizado pelo programa.

No panorama das políticas culturais atualmente em vigor, o Vale Cultura ${ }^{10}$ é a ação mais direta no sentido de interferir na dimensão financeira do acesso para os trabalhadores de classes mais baixas. No âmbito do CPV, contudo, nem mesmo a aceitação do Vale Cultura nos complexos beneficiados é uma exigência, embora grandes redes como o Cinemark, Kinoplex e Cinépolis já o aceitem. Kaufmann (2014) aponta que os exibidores responsabilizam a política de meia-entrada no Brasil como o principal fator que os impede de trabalhar com preços mais baixos. O que se observou na pesquisa de campo, por outro lado, é que o perfil de público que mais frequenta as novas salas é formado por jovens estudantes, não só porque possuem mais tempo livre para o lazer, mas também porque usufruem de preços mais baixos em qualquer dia da semana, sem depender das promoções

\footnotetext{
${ }^{10}$ Programa do Ministério da Cultura que realiza parceria com empresas e oferece R $\$ 50$ mensais, para trabalhadores com renda de até 5 salários mínimos, que podem ser gastos com produtos e serviços culturais.
} 
ou de clubes de vantagens. É de se questionar, portanto, se a inexistência da política de meia-entrada reduziria o valor global dos ingressos a ponto de ser financeiramente acessível para todos os segmentos de público ou se, pelo contrário, é ela quem garante que pelo menos os jovens de estratos sociais mais baixos tornem-se frequentadores assíduos.

Os clubes de vantagens e estratégias promocionais, embora estejam intimamente relacionados à dimensão econômica, também compõem a dimensão administrativa do acesso material. Outro aspecto relevante da dimensão administrativa que influencia na aceitação dos novos complexos é a estrutura oferecida não apenas pelas salas, mas pelos estabelecimentos onde estão localizadas. No Rio de Janeiro, apesar de a maioria das pessoas $(67 \%)$ considerar o ingresso barato, o alto índice de preferência pelas outras salas (33\%) pode ser justificado pela insatisfação com a variedade da programação, que será avaliada mais detalhadamente no próximo item, e pela estrutura da sala: $27 \%$ a avaliaram negativamente. Além das críticas à manutenção e às falhas na projeção e sistema de arcondicionado, algumas pessoas consideram que a pouca oferta de lojas e lanchonetes do supermercado, em comparação aos shoppings, influencia na escolha do cinema.

Em Hortolândia e Imperatriz, todas as pessoas que já conheciam a sala avaliaram a estrutura e a projeção positivamente, o que também explica o alto índice de preferência. Em Imperatriz, apesar de o outro cinema estar localizado em uma área mais central da cidade e de oferecer ingressos um pouco mais baratos (valor médio de R\$12), a nova sala do Imperial Shopping foi apontada como preferida por apresentar uma programação mais variada, uma estrutura melhor e mais confortável, além de mais opções de compras e alimentação que o Tocantins Shopping.

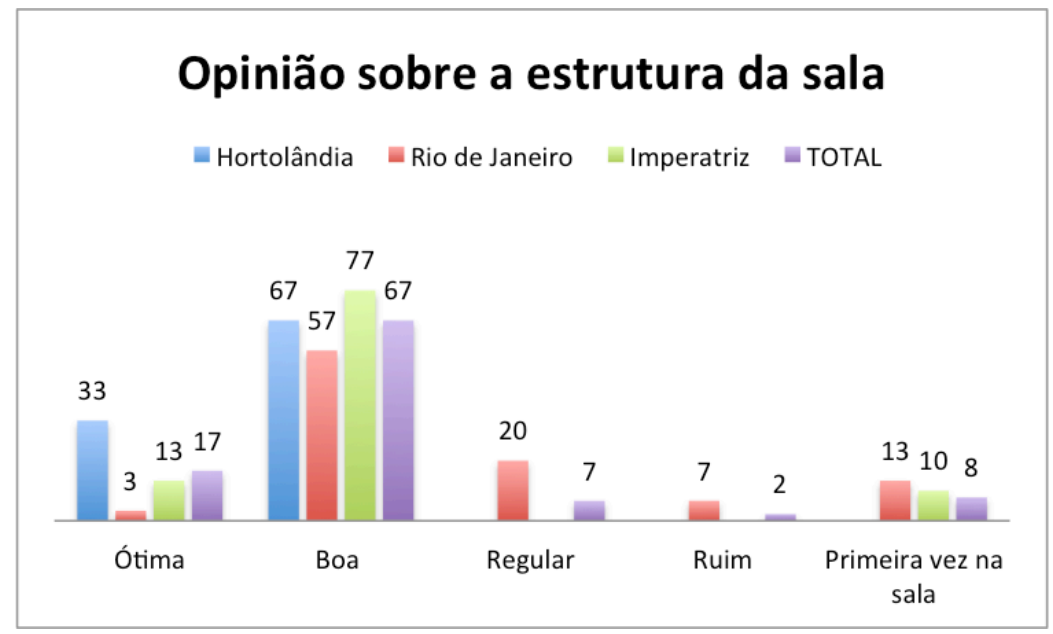

Gráfico 15 - Opinião sobre a estrutura da sala. Fonte: Elaboração própria. 
Ainda sob o ponto de vista administrativo, é possível constatar que o modelo de negócio das redes de multiplexes tende a concentrar e homogeneizar o planejamento e execução das estratégias de divulgação e atração do público. São as centrais de marketing e programação das redes de exibição, normalmente localizadas no eixo Rio-São Paulo, que definem quais são os filmes a serem exibidos e de que forma serão divulgados em todo país, o que dificulta a percepção das especificidades locais e regionais que podem influenciar o acesso dos espectadores. $\mathrm{O}$ caso de Imperatriz, por exemplo, mostra que um exibidor local como o Impera Cine pode ter mais autonomia e eficiência sobre sua divulgação, investindo em uma página do Facebook que registra mais de 24 mil seguidores, enquanto o Cinesystem do Imperial Shopping administra um grupo fechado com apenas 2,5 mil participantes.

A atuação do CPV na dimensão material do acesso revela que a distribuição geográfica das novas salas ainda apresenta uma concentração regional significativa, mas ao mesmo tempo responde às demandas de cada local e interfere positivamente na frequência das pessoas no cinema, ainda que em intensidades variáveis. Do ponto de vista econômico, o próprio modelo de consumo que faz parte do foco de incentivo do programa, bem como a ausência de estratégias mais contundentes no sentido de baratear os custo dos ingressos, apontam para a interferência da mercantilização na formulação da política, que ainda é frágil no sentido de atingir estratos sociais mais diversificados.

Mosco ressalta, a partir do que chama de mercantilização extensiva, que esse processo se estendeu a áreas institucionais como a educação pública, a cultura e as telecomunicações, que antes preservavam princípios de acesso universal, mas que atualmente têm sido alvo de privatizações, o que introduz a lógica econômica neoclássica do preço de custo e a gestão de acordo com os interesses dos que possuem poder comercial:

\footnotetext{
O processo de mercantilização adentrou lugares e práticas que antes tendiam a se organizar de acordo com uma lógica social diferente, baseada na universalidade, igualdade, participação social e cidadania, as quais, apesar de todas as deficiências levantadas, ampliavam os terrenos da ação social hoje crescentemente reduzida a uma lógica de mercado que equivale direitos a poder de consumo. (MOSCO, 1996, p.144, tradução nossa)
}

Embora o cinema, no Brasil, nunca tenha se caracterizado como um serviço público oferecido universalmente, é possível perceber que em outros momentos históricos houve 
uma conjuntura que favorecia a prática de ingressos a preços populares e a existência de salas não apenas nos bairros centrais das grandes cidades, mas também no interior e nas periferias. As condições para ampliação do acesso ao cinema certamente não são as mesmas dos anos 1970, especialmente quando se leva em consideração a capacidade de alcance da televisão e da Internet hoje. No entanto, o foco de atuação da política, além de se concentrar no modelo tradicional de exibição, o faz sob uma perspectiva majoritariamente comercial, atuando de forma muito restrita diante das possibilidades de acesso. Uma política pública não está livre das pressões e considerações do mercado, mas deve ser constituída de processos que privilegiem a igualdade, a diversidade e a participação diante da hegemonia do mercado.

Do ponto de vista das consequências da espacialização, é importante ressaltar que ela não interfere apenas na forma como os indivíduos e as empresas passam a se relacionar com o tempo e com o espaço, por meio da mídia e de tecnologias de comunicação, mas também influencia a forma como o Estado concebe e aplica a regulação do setor. Mosco ressalta que há uma tendência de se conceber a regulação como uma reação governamental diante de um dado problema. Dessa forma,

\footnotetext{
quando os formuladores de políticas e os analistas acadêmicos revisam a regulamentação do setor, eles tendem a examinar a prática do governo e argumentam sobre se a regulação é mais ou menos necessária. Assim, o debate sobre o papel do estado na indústria da comunicação frequentemente se resume à escolha entre regulamentação e desregulamentação. (MOSCO, 1996, p.176, tradução nossa)
}

Para o autor, eliminar a regulamentação governamental não é desregulamentar, mas expandir a regulação do mercado. Mosco defende que é preciso desmascarar o conceito de desregulação e considerar o papel constitutivo do Estado enquanto ente ativo na construção de diversas formas de regulação. Nesse sentido, ele destaca e critica quatro processos que caracterizam a atividade constitutiva do Estado atual. A comercialização é a substituição de formas de regulação baseadas no interesse público, no serviço público e na universalidade, por padrões de mercado que conferem maior ênfase à lucratividade. A liberalização caracteriza-se pela intervenção do Estado para expandir o número de empresas no mercado, com o argumento de que a concorrência acarreta a queda de preços, expande serviços e acelera o processo de inovação. A privatização é a venda de uma empresa estatal para a iniciativa privada, como uma emissora pública ou uma companhia 
telefônica, como forma de garantir a livre concorrência. O quarto processo é a internacionalização, ou seja, a criação, por parte dos governos, de suas próprias organizações regionais e globais que os integram em vários graus.

Entre esses processos, decorrentes tanto da mercantilização quanto da espacialização, os que se manifestam mais claramente no Cinema Perto de Você são a comercialização e a liberalização. Em relação ao primeiro processo, apesar de oferecer condições de crédito e investimento mais favoráveis para a criação de salas em cidades onde não há cinema ou com até 500 mil habitantes, a concretização dessa meta está sujeita à análise de mercado por parte das empresas exibidoras, que não enxergam nessas praças o potencial de lucro almejado. Por não conceber nenhuma outra estratégia, baseada no interesse público, que garanta a descentralização das salas e, consequentemente, a ampliação do acesso daqueles que não têm, o programa torna-se refém da regulação do mercado e acaba por privilegiar estados e cidades que não apresentam a mesma carência. Da mesma forma, a total ausência de uma política de preço de ingresso demonstra como o programa encara o acesso apenas como consumo, e não como direito à cultura, conferindo mais uma vez à regulação do mercado o controle de quais faixas de renda irão conseguir frequentar os cinemas financiados com verba pública e que deveriam, portanto, prezar pelo interesse público no seu funcionamento.

Já a perspectiva da liberalização reflete-se no raciocínio de que basta ofertar linhas de investimento e garantir juros mais baixos para realizar a inserção de novas empresas e, assim, promover a concorrência que leva à queda dos preços e à melhora dos serviços. $\mathrm{O}$ que se percebe é que apenas um número limitado de empresas consegue cumprir com as exigências financeiras e burocráticas do programa e que, apesar de ter contribuído consideravelmente para a expansão de exibidoras nacionais, a atividade ainda é controlada por poucas redes, o que contribui para a manutenção de um oligopólio no setor:

\footnotetext{
Os críticos rebatem [a liberalização] afirmando que é a substituição da regulação estatal pela regulação de um oligopólio privado, que realiza mandatos de preço, serviço e inovação que promovem os interesses de um cartel de oligopólio e de seus clientes mais privilegiados. (MOSCO, 2009, p.177, tradução nossa)
}

A forma como o incentivo é concebido e implementado, portanto, acaba favorecendo grandes empresas, inclusive internacionais, em vez de promover uma diversificação concreta. 
Mosco também ressalta que outra dimensão da espacialização, a da convergência tempo-espaço e custo-espaço, é o reforço de antigas desigualdades de acesso:

\begin{abstract}
Especificamente, a aglomeração espacial impõe novas hierarquias que concentram riqueza e poder em algumas cidades, enquanto outras declinam. Também estabelece hierarquias que concentram riqueza e poder em algumas partes das cidades, enquanto outras declinam. Essas disparidades regionais crescem junto com as disparidades de classes sociais. (MOSCO, 2009, p.174, tradução nossa)
\end{abstract}

A concentração da riqueza e do poder econômico em algumas cidades e em alguns bairros dessas cidades cria uma significativa concentração de poder econômico nessas áreas, enquanto empurra as pessoas com menor poder aquisitivo para as periferias. Quando formas de lazer e cultura como o cinema estão diretamente atreladas ao shopping, elas só vão chegar aos locais com grande potencial de consumo. Se, por um lado, a informação circula mais rápido e a comunicação transcende as barreiras físicas, a maior parte da população ainda tem que vencer não apenas a barreira financeira, mas também as barreiras geográfica e temporal, relacionadas à distância entre a moradia e o cinema e ao tempo dispendido nesse deslocamento em meios de transportes ineficientes, seja pela escassez nas áreas pouco habitadas, seja pelo congestionamento nos grandes centros urbanos.

Dessa forma, o programa é eficaz no incentivo à construção e modernização das salas, porém carece de estratégias mais contundentes para garantir a descentralização geográfica e a inclusão de novos estratos sociais nos cinemas. Juros mais baixos e maior percentual de empréstimo para a construção de salas nas cidades que formam os grupos de prioridade do programa, a desoneração tributária sobre produtos e serviços, e a digitalização, que barateia sensivelmente o custo da atividade de exibição cinematográfica, não têm se revelado condições suficientes para alcançar esses objetivos. Por conta dos prérequisitos financeiros e dos trâmites burocráticos que impõe às empresas pleiteantes, o programa beneficia prioritariamente o modelo de exibição adotado pelas grandes redes de multiplexes, o que acarreta a construção das salas apenas em shoppings, a implementação de um perfil de cinema que é altamente dispendioso e cujo custo é transferido para o espectador.

Para atrair exibidores locais e garantir a descentralização, é preciso facilitar o acesso aos empréstimos e investimentos do programa. Em março de 2014, houve uma primeira tentativa neste sentido, quando a Instrução Normativa $n^{0} 1.446$ simplificou o 
processo de habilitação de projetos no Recine, mas os trâmites para a linha de crédito e investimento não foram formulados de maneira a contemplar pequenas empresas que queiram abrir um cinema, por exemplo. Ao mesmo tempo em que minimiza os riscos do investimento, tal medida gera dependência em relação às empresas já estabelecidas no setor, que nem sempre possuem capacidade ou interesse de atingir as cidades de menor porte no país. Conforme apontou a pesquisa de campo, são as cidades com nenhuma ou baixíssima oferta que possuem o maior potencial de formação de novos espectadores. A inclusão de outros perfis e estratos sociais de público, entretanto, não dependem unicamente da existência do cinema.

\subsection{Acesso cultural e simbólico e a hegemonia dos grandes produtores de conteúdo}

A dimensão material é sem dúvida um traço decisivo na concretização do acesso ao cinema, mas haver salas em uma localização alcançável e possuir os meios materiais necessários (recursos financeiros e disponibilidade) não são as únicas condições quando se analisa especificamente o acesso aos filmes nacionais. A dimensão cultural e simbólica do acesso, relacionada aos hábitos e costumes dos espectadores e seus repertórios narrativos e estéticos, desempenha um papel importante na relação entre o público e o cinema e, mais do que preferências individuais, está intimamente ligada à constituição do mercado cinematográfico no Brasil e no mundo, desde a concepção dos filmes à sua recepção.

Além da crise de produção do início da década de 1990, o modelo de negócio do cinema, tal como se firmou desde então, afastou a produção nacional das telas e tornou o público desacostumado a estes filmes. O novo modelo de distribuição e exibição realizado pelas majors é pautado pelo lançamento simultâneo no maior número possível de salas e por ostensivas estratégias de publicidade e marketing, o que não é financeiramente viável para a maioria dos filmes brasileiros. Como aponta Karine dos Santos Ruy, em seu estudo sobre as características de distribuição dos filmes nacionais de maior bilheteria entre 2003 e 2008, apesar de as políticas públicas terem viabilizado, nos últimos anos, um grande número de produções:

A distribuição e exibição, contudo, não foram abarcadas pelo Estado, deixando a grande maioria dos filmes nacionais desprovidos de qualquer espécie de auxílio estratégico para se inserir no disputado circuito de exibição tradicional. Ao não 
atrair o interesse de majors do setor, e consequentemente condenados a um espaço limitado na cadeia de exibição - ou a espaço algum -, uma leva de filmes brasileiros é desconhecida de seus espectadores em potencial. (RUY, 2011, p.35)

Do ponto de vista da distribuição, o cenário já não é o mesmo do constatado na década de 2000, quando as majors dominavam o mercado não apenas de filmes estrangeiros, mas também conquistavam a maior parte do público e bilheteria dos filmes nacionais. Dados mais recentes da Ancine mostram que houve uma inversão na participação estrangeira na comercialização dos títulos brasileiros nos últimos anos: em 2009, as distribuidoras estrangeiras foram responsáveis por $21 \%$ dos títulos nacionais, os quais obtiveram mais de $60 \%$ do mercado. Já em 2014, o percentual de filmes nacionais distribuídos por empresas estrangeiras caiu para $5 \%$ e a renda alcançada pelos filmes comercializados por elas representaram $19,5 \%$ do total. Cerca de $80 \%$ da participação de mercado de títulos nacionais, portanto, foram atingidos pelos filmes distribuídos por empresas nacionais.

Quanto à exibição, já vimos que o Cinema Perto de Você é a principal ação de fomento ao setor desde a criação da Ancine. As diretrizes do programa revelam, entretanto, que a política carece de ações para incentivar a presença do filme nacional nas salas, o que poderia ser uma estratégia de formação de público. Assim como qualquer cinema comercial, as salas construídas ou reformadas com recursos do CPV têm apenas a obrigação de cumprir com a cota de tela. ${ }^{11}$ Para Selmo Kaufmann (2014), apesar de não ser uma medida direta, o cinema nacional ganha mais espaço, pois mais salas significam mais cota de tela a ser cumprida.

O que se percebe, contudo, é que a programação das salas incentivadas segue o padrão do grande mercado e exibe prioritariamente os títulos de maior potencial de renda. Analisando o perfil de programação de três salas construídas com recursos do CPV em diferentes estados e administradas por diferentes empresas, entre julho de 2013 e junho de 2014, é possível perceber que o filme nacional ocupa aproximadamente $20 \%$ da grade. Foram exibidos apenas 32 títulos brasileiros, 20 dos quais coproduzidos ou apoiados pela Globo Filmes, quando o total de lançamentos nacionais no período foi de 130 filmes

\footnotetext{
${ }^{11}$ O Decreto n. 8.176, de 27 de dezembro de 2013, ajustou o total de dias e de filmes brasileiros a serem exibidos pelos cinemas comerciais de acordo com a quantidade de salas dos complexos, variando de 28 a 63 dias por sala e de 3 a 24 títulos por ano.
} 
(Apêndice 1). O simples aumento do número de salas, portanto, não garante a diversidade nem assegura mais janela para o conjunto das produções nacionais.

Este panorama demonstra, ainda, que o fato de as distribuidoras nacionais terem conseguido retomar maior participação na comercialização dos filmes brasileiros não interferiu no padrão de comercialização herdado da indústria norte-americana: a maior parte dos filmes que conseguem uma boa inserção no mercado está associada a empresas com aporte financeiro e midiático capazes de fazer o produto circular de forma massiva. Além do grande número de cópias, que conseguem atingir mais da metade dos complexos existentes no país já na primeira semana, os altos investimentos em publicidade também têm reflexos nas escolhas do público. Cerca de 30\% dos entrevistados afirmaram que escolhem os filmes por conta de propagandas na televisão e $41 \%$, pela divulgação na Internet. A televisão, portanto, ainda desempenha um papel importante na divulgação e o alto custo de inserção de um comercial não está ao alcance da maioria dos filmes nacionais. Ao observar os lançamentos dos últimos cinco anos, constatamos que $90 \%$ dos títulos brasileiros com mais de 500 mil espectadores foram coproduzidos ou apoiados pela Globo Filmes, que utiliza todo o aparato midiático das Organizações Globo para divulgação.

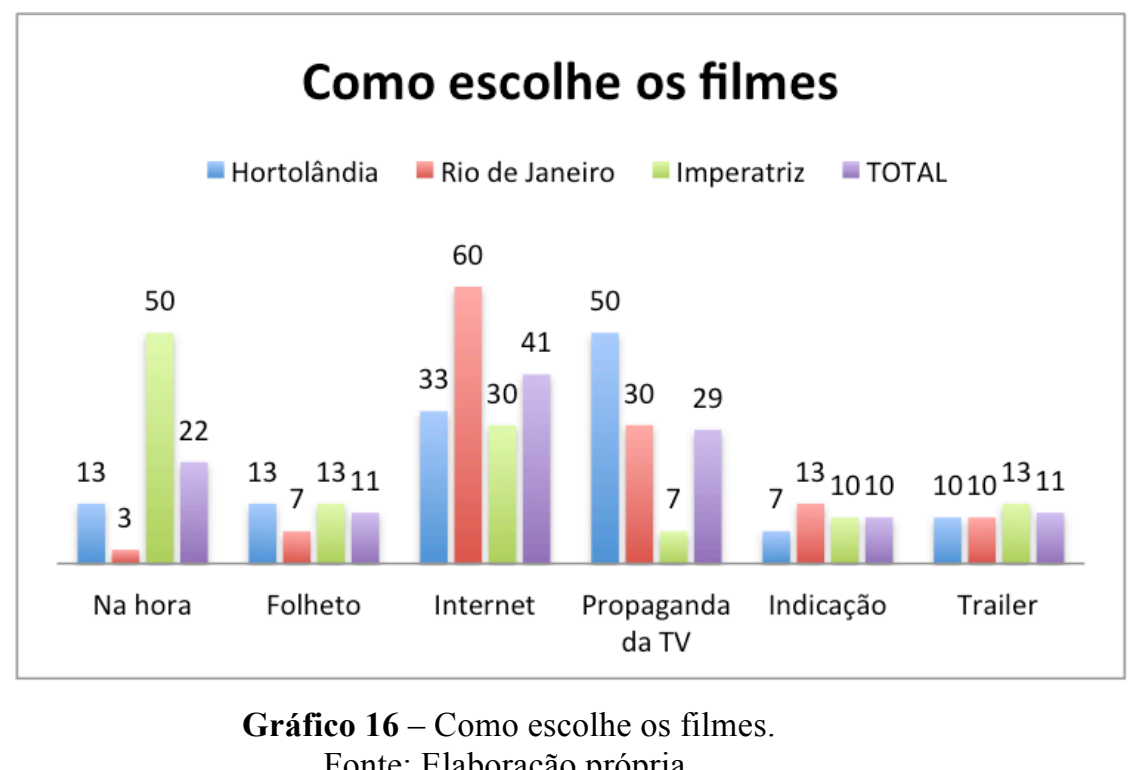

Esta participação da Globo Filmes aponta para uma concentração excessiva do mercado, porém tem sido eficiente em atrair novamente o grande público para filmes 
nacionais. Nas três cidades, a maior parte das pessoas afirmou ter o costume de assistir a filmes nacionais, sendo frequente o comentário de que a nossa produção melhorou de qualidade nos últimos anos. Entre os que não costumam assistir a filmes brasileiros, muitos consideram que os enredos são menos interessantes que os dos filmes estrangeiros e disseram se incomodar com os excessos de nudez e palavrões.

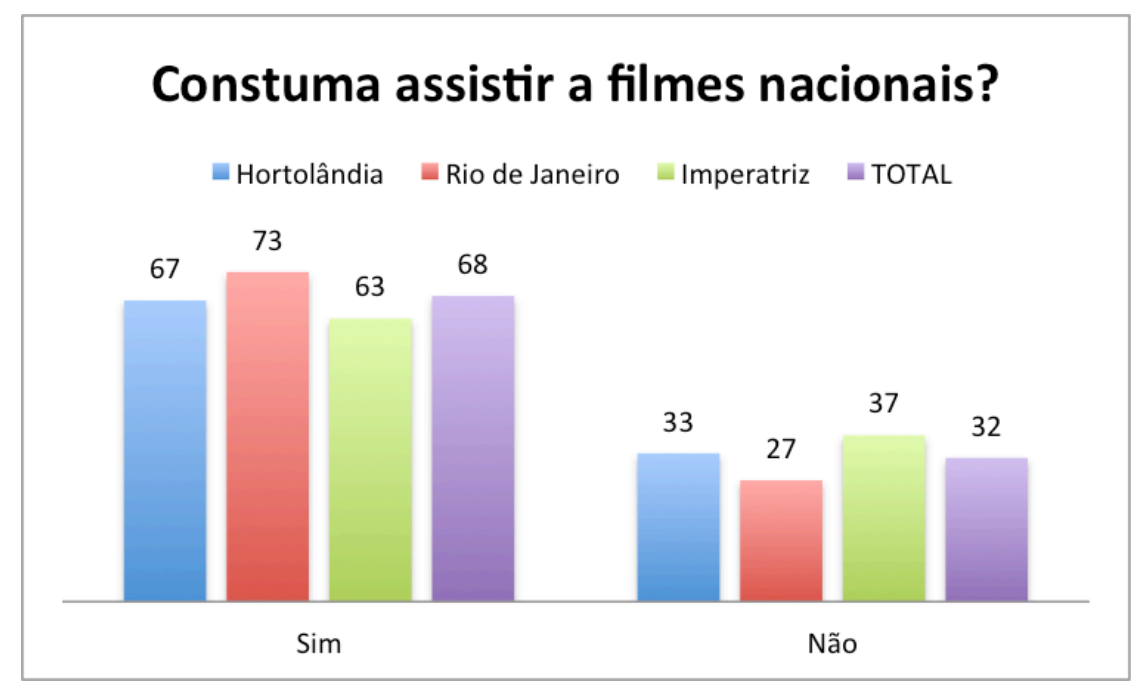

Gráfico 17 - Costuma assistir a filmes nacionais? Fonte: Elaboração própria.

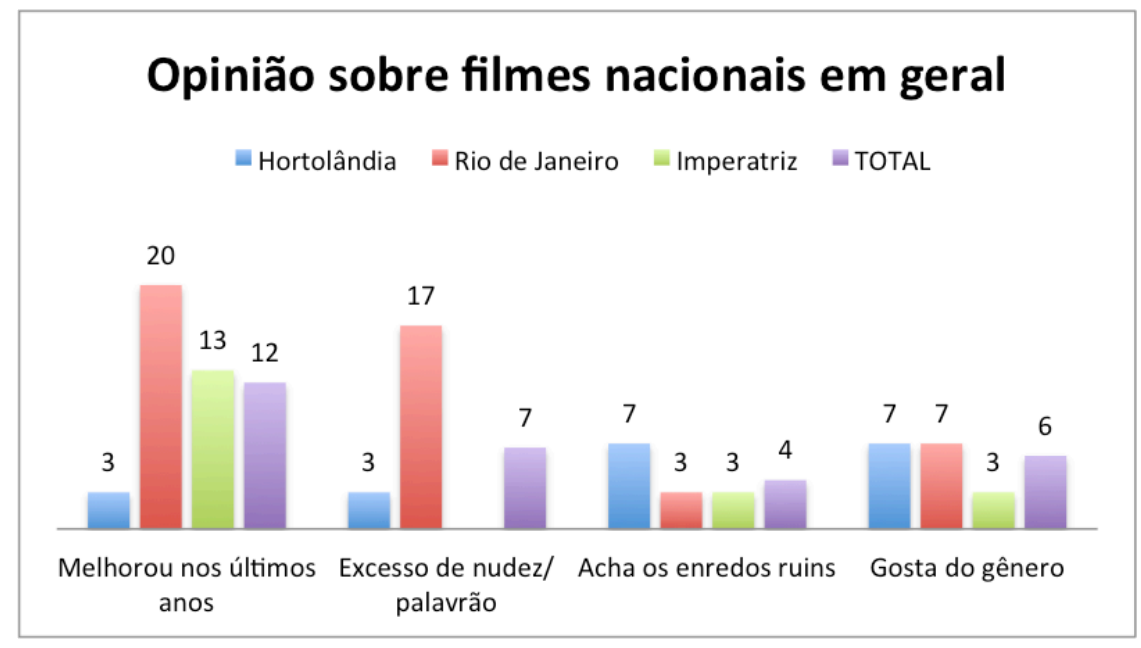

Gráfico 18 - Opinião sobre filmes nacionais em geral. Fonte: Elaboração própria. 
Esta rejeição provavelmente está relacionada a um estereótipo do filme nacional que remonta à produção da pornochanchada, mas que se distancia do perfil dos filmes de maior sucesso nos últimos anos. Títulos como Lisbela e o prisioneiro, Se eu fosse você, Dois filhos de Francisco e vários outros alinham-se estética e narrativamente ao modelo televisivo adotado pela Globo, funcionando como uma paradoxal via de mão dupla. Se, por um lado, aproveitam a familiaridade do público com o formato para atraí-lo de volta às salas e, assim, contribuir para a criação do hábito de assistir a filmes nacionais, por outro lado, consolidam um padrão de mercado e de consumo que é incompatível com a promoção da diversidade estético-narrativa das produções brasileiras nas salas comerciais. Conforme avalia Ruy,

\footnotetext{
Em um mercado que ainda tenta se estruturar, produzir filmes seguindo apenas um padrão de consumo capaz de garantir seu "sucesso" em termos de bilheteria pode ser entendido como uma prática constrangedora à diversidade das narrativas audiovisuais que historicamente diferencia as cinematografias nacionais. Contudo, pelos movimentos que se observam nos últimos anos, essa reprodução interna de um modelo de indústria cinematográfica assimétrica, no qual os grandes investimentos em distribuição e marketing transformam-se em componentes quase imprescindíveis para a mobilização de espectadores, está conseguindo se consolidar como um novo padrão para o mercado de cinema brasileiro. (RUY, 2011, p.42)
}

O público entrevistado demonstrou aceitação em relação a esse modelo, já que metade das pessoas considera boa a oferta de filmes nacionais nas salas visitadas. Apenas 2 dos 15 títulos nacionais mencionados nas entrevistas não são coproduções da Globo Filmes. Entre os mais lembrados estão: Até que a sorte nos separe, SOS mulheres ao mar, Minha mãe é uma peça e Vai que dá certo. É relevante notar, porém, que um alto número de pessoas também afirmou que não observa a programação de filmes brasileiros nas salas, revelando que eles não são, em princípio, uma tendência de escolha e que, mesmo se tratando dos títulos de maior aporte publicitário, também sofrem com a concorrência em relação aos filmes americanos. 


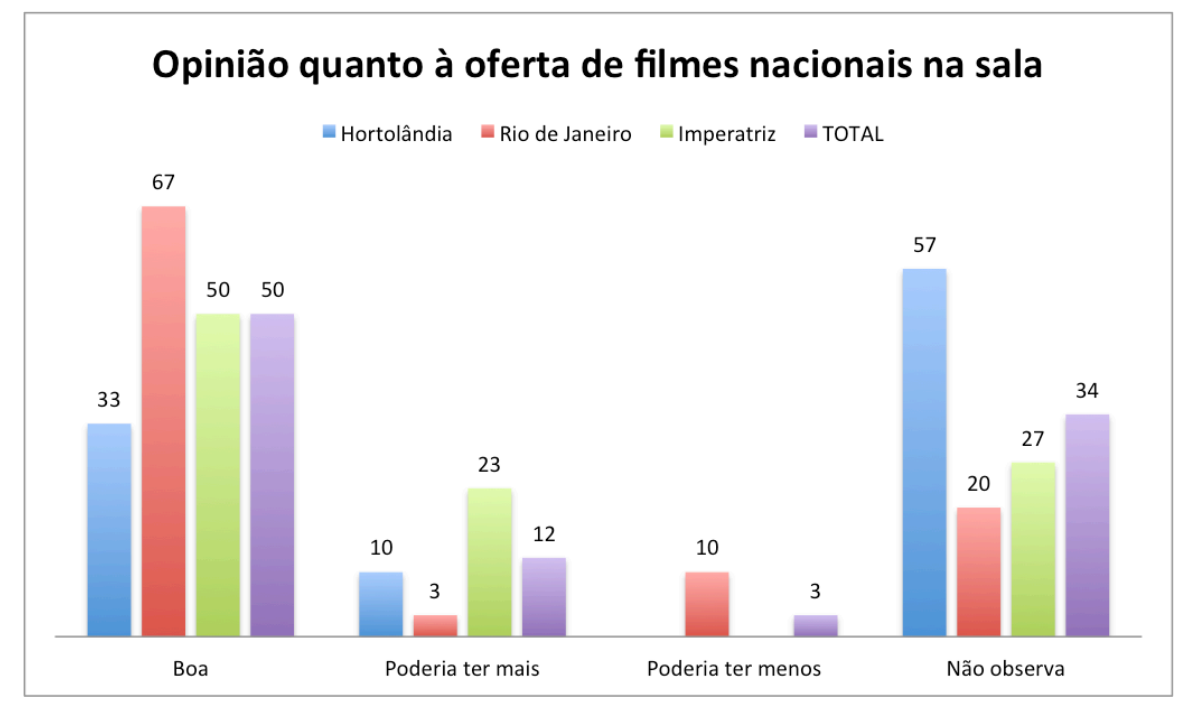

Gráfico 19 - Opinião quanto à oferta de filmes nacionais na sala. Fonte: Elaboração própria.

Quanto à programação geral nas salas visitadas, é possível notar que o público do Rio de Janeiro é mais exigente. Em Hortolândia e Imperatriz, 83\% dos entrevistados demonstraram estar satisfeitos com a programação, afirmando que sempre há algum filme de interesse em cartaz e que a variedade é maior que em outros cinemas da região. Já no Rio de Janeiro, onde há uma maior oferta de salas, algumas com perfil diferenciado de programação, 33\% consideram a programação do Cine 10 ruim ou regular.

\section{Opinião sobre a programação da sala}

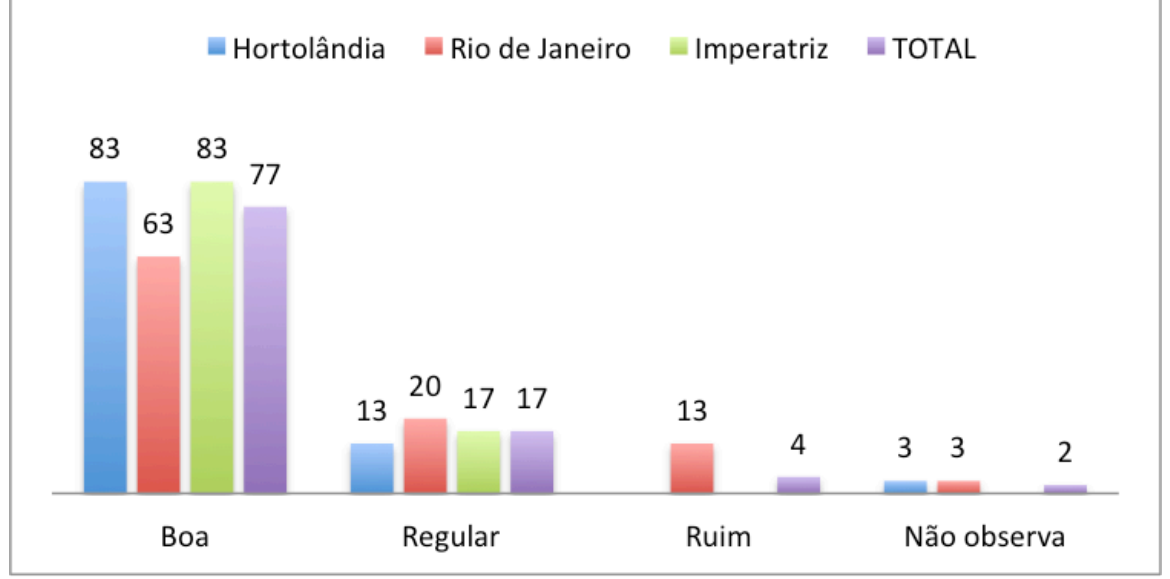

Gráfico 20 - Opinião sobre a programação da sala. Fonte: Elaboração própria. 
O nível de exigência mais alto no Rio de Janeiro pode estar relacionado a dois fatores. O primeiro é a escolaridade, já que a maior parte dos entrevistados (57\%) nesta cidade possui nível técnico ou superior. Foi o público, por exemplo, que mais demonstrou insatisfação com a predominância de filmes dublados na programação do Cine 10. A menor escolaridade foi a de Hortolândia, com $67 \%$ de nível fundamental ou médio. Imperatriz apresentou índices iguais para fundamental ou médio $(50 \%)$ e técnico ou superior $(50 \%)$. A escolaridade isoladamente, entretanto, não justifica a diferença de opinião no Rio de Janeiro, já que o índice de entrevistados com nível superior em Imperatriz é ligeiramente menor e, nesta cidade, o nível de aprovação da programação foi tão alto quanto o de Hortolândia.

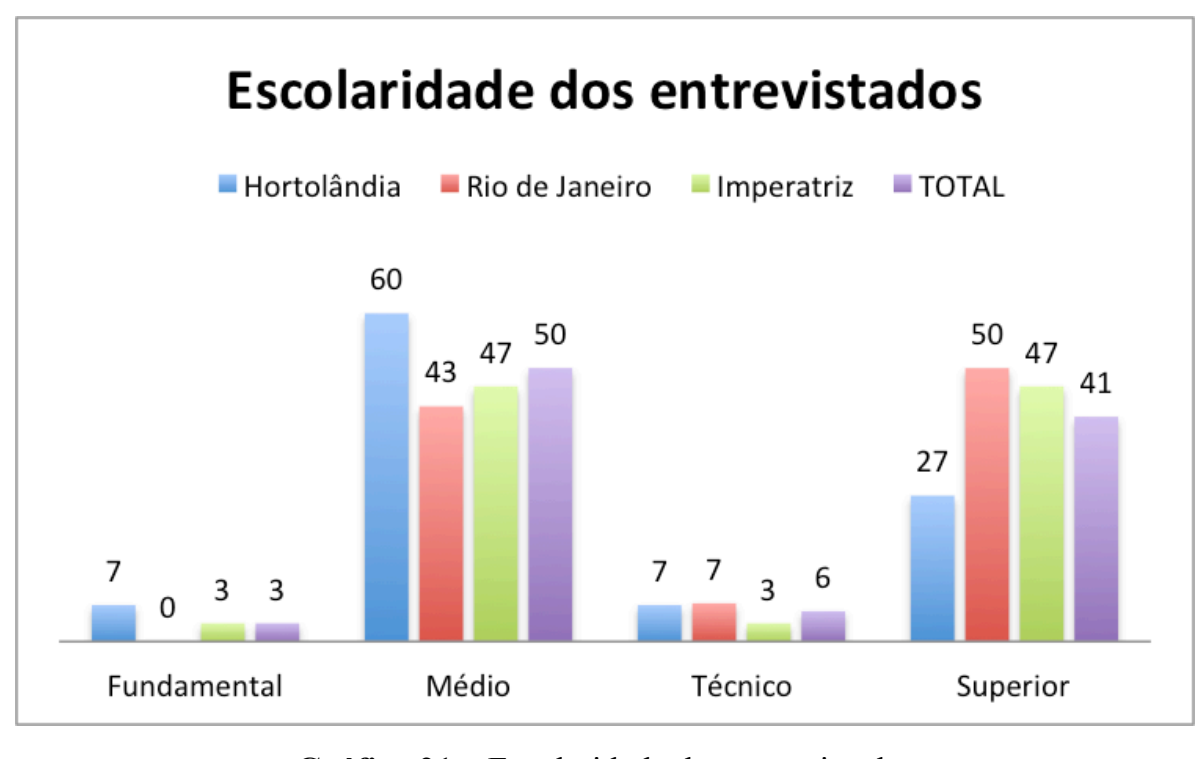

Gráfico 21 - Escolaridade dos entrevistados Fonte: Elaboração própria.

O segundo fator, igualmente relevante, é a maior oferta e variedade de informação, lazer e cultura disponível em uma cidade grande como o Rio de Janeiro, o que permite que parte significativa do público carioca demande uma programação de cinema mais diversificada. A reclamação mais constante foi a de que, no Cine 10, são exibidos somente filmes de grande apelo comercial e que nem mesmo os filmes indicados ao Oscar chegam à sala. Vários entrevistados afirmaram que deixaram de assistir a filmes de seu interesse porque não dispunham de tempo e transporte para se deslocar até a Zona Sul, onde há um circuito de salas com programação mais alternativa. 
Da mesma forma que Landini, Cowes e D'Amore (2014, p.236) ressaltam que uma limitada alfabetização em saúde - entendida como a capacidade dos usuários de obter e processar informações que permitam prevenir doenças e promover a saúde - pode se converter em uma barreira de acesso ao sistema de cuidados, as limitações educacionais e um repertório cultural e audiovisual mais restrito também podem se tornar um entrave à procura e fruição de filmes que não utilizem os padrões estéticos e narrativos com os quais o grande público está mais acostumado, para os quais foi "alfabetizado" pelas telenovelas e filmes blockbusters americanos. De todo modo, se os autores fazem uma reflexão crítica sobre a tendência de se pensar a alfabetização em saúde centrada nos conhecimentos e capacidades dos usuários, eximindo os profissionais e as estruturas dos sistemas, também é preciso que produtores e realizadores reflitam sobre suas estratégias de comunicação com os espectadores e que as políticas de cultura formulem ações mais efetivas para a formação de público, com o cuidado de não adotar uma perspectiva autoritária que pressuponha o que deve ou não ser produzido, exibido ou apreciado, mas sim permitindo a diversidade de olhares e a possibilidade ampliada de escolha.

Para Autran (2009, p.126), “ao longo da década de 1990 a centralidade da articulação política visando à necessária reestruturação das formas de financiamento público à produção não facilitou a elaboração de uma reflexão acerca do público do cinema brasileiro". Em sua análise sobre as noções de público e mercado exibidor que orientaram tanto a corporação cinematográfica quanto as políticas públicas de cinema, entre 1990 e 2005, Autran demonstra que a transição de modelo de exibição foi concomitante a uma mudança da forma de relação entre o Estado e o setor:

\footnotetext{
Ao invés de um órgão estatal centralizado [a Embrafilme] que definia a forma da liberação dos recursos financeiros e que atuava politicamente dentro do aparelho do Estado em busca de legislação protecionista, recursos financeiros, etc.; a partir dos anos 1990 estrutura-se um modo privado de gerir os recursos públicos através das empresas que se utilizam das leis de incentivo, o Estado apenas autoriza os projetos cinematográficos a captar recursos, fiscaliza o sistema e delibera sobre qual o montante anual de recursos a serem incentivados [por meio da Ancine]. (AUTRAN, p.122, grifos nossos)
}

Atualmente, mesmo que as leis de incentivo não sejam mais os únicos mecanismos de fomento ao cinema e que o Fundo Setorial tenha ampliado e diversificado os recursos, o produto cinematográfico brasileiro depende integralmente das verbas públicas para a sua realização e não consegue estabelecer uma relação orgânica com a exibição em cinemas, 
televisão ou vídeo doméstico. É possível que falte à formulação e à implementação das políticas públicas de cinema o exercício de transcender a tríade de mercado produçãodistribuição-exibição e deixar que o público, com seus hábitos, demandas, preferências, formas de se relacionar com o cinema, torne-se um foco de reflexão. Naturalizar o comportamento do público unicamente como uma tendência de mercado não contribui para a elaboração de ações mais efetivas de acesso e formação.

Se a finalidade de um filme é ser visto e se a meta da política é tornar a atividade cinematográfica sustentável, é preciso que os esforços centrados na produção e na infraestrutura se equilibrem com a formulação de estratégias que potencializem a recepção. A ênfase verificada nas dimensões materiais do acesso, especialmente em seus aspectos geográficos e financeiros, transparece não apenas uma perspectiva mercantilizada da política de acesso ao cinema, mas também indica que a atuação na dimensão cultural e simbólica do acesso requer ações mais profundas e complexas, que envolvem a garantia de educação de qualidade que promova a autonomia e a inserção coletiva dos cidadãos, bem como o incentivo à formação de hábitos mais diversos de fruição cultural. Para além de uma constatação das desigualdades de acesso material, é relevante questionar como a estruturação das relações de poder (econômico, cultural e simbólico) constrói um discurso hegemônico em torno do cinema e da cultura em geral:

\footnotetext{
A hegemonia difere da ideologia e dos valores na medida em que é a formação de curso de imagem e informação para produzir um mapa de senso comum, que é tão suficientemente persuasivo para a maioria das pessoas que oferece as coordenadas sociais e culturais para definir a atitude "natural" da vida social. A hegemonia é, portanto, mais valiosa que o conceito de ideologia, porque não é simplesmente imposta pelo poder de classe, mas constituída organicamente pelas geometrias dinâmicas do poder embutidos nas relações e organizações sociais em toda a sociedade. É mais útil do que o conceito de valores, porque a hegemonia incorpora tanto poder quanto senso comum enquanto os valores deixam pouco espaço para o poder. (MOSCO, 2009, p.206, tradução nossa, grifo do autor)
}

As disparidades de acesso, não só ao produto final, mas também aos meios de produção e distribuição do cinema, criam relações que operam no sentido de construir uma hegemonia da cultura como consumo, da dicotomia entre produtores e espectadores, do cinema comercial como o único modelo viável e da padronização decorrente disso. Esse pensamento hegemônico penetra a formulação do CPV e, além das consequências já apontadas, contribui para a reprodução de uma concepção de cinema que aparta o público 
da percepção de que todos somos produtores de cultura e que devemos participar não apenas por meio do consumo, mas também pela construção ativa da política, demandando mais diversidade e vias de concretização do acesso em todas as suas dimensões. A divisão entre uma "classe criativa" e uma "classe consumidora" nada mais é que a tradução do poder intelectual em poder econômico.

Não é politicamente neutro o discurso hegemônico de que há um livre fluxo de informação e de que a oferta é regulada pelo livre poder e capacidade de escolha do público, pois este é um instrumento que mascara as disparidades de produção e difusão dos filmes e de acesso dos espectadores. Embora seja importante reconhecer o poder ativo do público, é preciso ressaltar que, na forma como o cinema é majoritariamente estabelecido, este poder está circunscrito aos limites pautados pelo mercado, que define o que deve ser produzido, como deve ser distribuído e quanto custa. As empresas que dominam o mercado do audiovisual, tanto nacional quanto internacionalmente, reforçam a hegemonia de seus modelos de negócio e dos conteúdos que lhes são mais facilmente rentáveis, por sua própria repetição.

Por outro lado, Mosco aponta que, embora o consenso seja uma poderosa forma de controle, a sua construção implica resistência e o potencial de criação de formas alternativas de senso comum: "Assim, embora a hegemonia seja um meio central para realizar a estruturação das relações sociais, ela não garante sua reprodução" (MOSCO, 2009, p.208, tradução nossa). O próprio capitalismo traz consigo o dilema de tentar incorporar ao mercado as minorias, pouco representadas pelos poderes hegemônicos, e de se ver diante da necessidade de criar novas mensagens e imagens, que têm o potencial de desafiar as narrativas dominantes. Nessas fissuras, abre-se o espaço para contestar o modelo dominante e a representação das minorias, e reivindicar maior controle social sobre o mercado:

O capitalismo usa o poder de classe para estruturar as relações sociais de produção e consumo, mas não pode garantir que isso irá funcionar com sucesso, principalmente porque as pessoas que participam dessas práticas estruturantes são autorreflexivas e capazes de agir socialmente de acordo com suas próprias necessidades e interesses, embora distorcidas e parcialmente formuladas. Uma consequência disso é que as pessoas reconhecem a oportunidade na erosão dos laços tradicionais e assumem um papel ativo no processo de sua reestruturação. Como resultado, o processo de reprodução é contestado e as fontes de resistência social ao capitalismo são multiplicadas, mas também dispersas. (MOSCO, 2009, p.198, tradução nossa) 
Dessa forma, o Cinema Perto de Você responde a uma demanda social de mais acesso ao cinema, principalmente em áreas mais afastadas dos grandes centros econômicos, mas apresenta uma formulação e uma implementação tão fortemente pautadas pela mercantilização, pela espacialização e pela hegemonia do cinema comercial que não consegue interferir de forma significativa no acesso dos grupos sociais e regiões que diz priorizar. O programa, em seu curto tempo de funcionamento, apresenta diversos méritos, entre os quais se destacam o aumento e modernização do parque exibidor e a ampliação da oferta em cidades ou bairros que apresentam carência, porém dentro dos limites estabelecidos pelo mercado. Além disso, ao não interferir na regulação do preço dos ingressos e na programação das salas financiadas, termina por reforçar fatores etários e financeiros e contribuir para a consolidação do cinema comercial hegemônico. 


\section{CONSIDERAÇÕES FINAIS}

Esta pesquisa nasceu da observação de que a produção de filmes brasileiros de longa-metragem voltou a crescer consideravelmente na última década e de que isto se devia, em grande parte, à ampliação e diversificação de mecanismos de incentivo estatais, tanto federais quanto estaduais e municipais. Os relatórios de exibição publicados anualmente pela Ancine, contudo, mostravam que a média de público e renda dos filmes nacionais não sofreu maiores alterações, com exceção dos anos em que havia títulos de grande sucesso isolado. Partimos da hipótese de que as políticas públicas voltadas para difusão e acesso ao cinema eram secundárias diante dos incentivos à produção e que, por isso, não conseguiam interferir de forma mais enfática no desempenho das produções nacionais ao longo dos anos. Realizamos um levantamento das políticas federais e constatamos que há vários mecanismos e programas com foco na difusão e no acesso. Apesar de recente, o Cinema Perto de Você é o que apresenta o maior aporte de investimentos e o único que se propõe a atuar diretamente na cadeia produtiva do setor, e não apenas exercer influência em circuitos alternativos. Por esses motivos, foi escolhido como objeto para este estudo de caso e como ponto de partida para uma reflexão acerca do acesso na política audiovisual em vigor no Brasil. Além disso, a partir da construção de um estado da arte da pesquisa acadêmica sobre o tema, foi possível perceber que o acesso é um conceito e uma etapa do processo pouco estudado e que merece um olhar mais aprofundado.

Dessa forma, nossa proposta foi investigar a formulação e a implementação do Cinema Perto de Você, com o objetivo de entender qual a perspectiva de acesso adotada pelo programa e quais os interesses, atores e relações de poder envolvidos nesse processo, para tentar explicar de que forma ele contribui para o acesso ao cinema e que limitações apresenta. Como referencial teórico, consideramos que a abordagem mais adequada para a interpretação das nossas questões de pesquisa é a Economia Política da Comunicação. Primeiramente, por conta de sua postura teórico-metodológica, que encara o processo social enquanto uma transformação histórica, enxerga a totalidade das relações sociais e a constituição mútua das dimensões política e econômica, está comprometida com fundamentos de justiça social e entende a transformação social e a intervenção social como uma forma de conhecimento. Em segundo lugar, porque apresenta uma epistemologia 
realista, inclusiva, constitutiva e crítica, conforme apontado no segundo capítulo e retomado na análise do programa. Do arcabouço teórico da EPC, trouxemos os processos de mercantilização, espacialização e estruturação como pontos de partida para a interpretação dos dados e, a partir de outras contribuições teóricas, tentamos construir conceitos-chave que permearam todo o trabalho, entre os quais se destacam o conceito de política pública de cultura, os conceitos de Estado e hegemonia, e o conceito de acesso aplicado à cultura.

Retomando os principais marcos das relações entre o setor cinematográfico e o Estado brasileiro ao longo da história, foi possível constatar que, até a criação do INC e sua posterior fusão com a Embrafilme, não houve a implementação de uma política pública propriamente dita voltada para o cinema, mas sim medidas de incentivo pontuais, como o estabelecimento da cota de tela e a Lei da Dobra, ou o financiamento de filmes via empresas e bancos estatais. Com a atuação da Embrafilme como coprodutora e distribuidora dos filmes nacionais, a produção começou a crescer e a ocupar um lugar de importância nas salas de cinema e nos hábitos do público. Apesar dos avanços, essa política centralizadora tendeu a privilegiar grupos específicos de produtores e a suprimir os pequenos distribuidores nacionais.

No início da década de 1990, vimos como a atividade era totalmente dependente do incentivo estatal e minguou diante da total ausência de políticas voltadas para o cinema. A segunda metade da década foi marcada por uma política de incentivo via isenção fiscal, que permitiu a retomada da produção, mas não garantiu diversidade e equidade na obtenção dos recursos, sendo, portanto, uma política bastante limitada. Com o estabelecimento da Ancine e, especialmente, após a criação do Fundo Setorial do Audiovisual, constitui-se uma política cinematográfica mais ampla e diversificada, que tenta atuar nos diversos elos da cadeia de produção, desde o desenvolvimento dos projetos à exibição. Constatamos que esta política tem sido mais eficaz na garantia do aumento e da estabilização da produção e da nacionalização da distribuição, porém ainda age de forma incipiente nos pontos críticos que dificultam a difusão da produção independente e o acesso dos espectadores ao cinema e às obras nacionais, como o domínio de mercado, tanto na distribuição quanto na exibição, por parte de grandes conglomerados estrangeiros, e a hegemonia da Globo na produção e veiculação de conteúdo na televisão e no cinema. 
A partir da análise dos documentos levantados e de uma pesquisa de campo em três cinemas contemplados, nas cidades de Hortolândia, Rio de Janeiro e Imperatriz, foi possível constatar que, embora o Cinema Perto de Você seja o principal programa de acesso ao cinema hoje e vise ampliar, modernizar e descentralizar o parque exibidor, além de incluir público de faixas de renda mais baixas, a maneira como foram formuladas suas ações consegue atingir com sucesso apenas as metas de digitalização e aumento do número de salas. A maior parte das salas de cinema do país concentra-se nas regiões Sul e Sudeste e em municípios com mais de 500 mil habitantes e o programa acaba reforçando essa concentração, já que $77,5 \%$ das novas salas contempladas encontram-se nestas regiões e mais da metade, em cidades grandes. A inclusão de novas faixas de espectadores também é tímida, já que não há uma política de preço de ingresso. A maioria dos entrevistados já costumava frequentar outras salas de cinema e cerca da metade passou a ir com mais frequência por conta da proximidade ou de atrativos da nova sala, o que leva à conclusão de que não há propriamente a inclusão de espectadores, mas o aumento de frequência entre aqueles que já tinham acesso. Do ponto de vista da programação, foi possível perceber uma total ausência de medidas de incentivo à presença do cinema nacional. Chegam aos cinemas apenas os filmes com grande número de cópias e forte aparato de divulgação, a maioria deles coproduzida pela Globo Filmes. Dessa forma, as salas do CPV respondem a uma demanda de público nos locais onde são implementadas, porém não interferem de forma significativa nas barreiras de acesso econômico, financeiro e cultural.

Avaliamos que essa tendência decorre dos processos de mercantilização da sociedade, que avança também sobre o Estado e sobre as políticas públicas, de espacialização, que contribui para o domínio de grandes conglomerados internacionais de mídia e para a falta de regulação estatal do setor, e de estruturação, que constrói hegemonia em torno do modelo comercial de produção, distribuição e exibição dos filmes, bem como da relação com a cultura pela via do consumo, não do exercício de um direito. O modelo de exibição multiplex tornou-se hegemônico no mundo e, além de depender de grandes investimentos, apresenta um alto custo de manutenção, especialmente porque está atrelado ao funcionamento em shoppings. Ao adotar esse modelo como foco, o CPV rende-se às prerrogativas do mercado e da sustentabilidade do negócio (ou lucratividade, por que não dizer?) e não consegue atingir os objetivos de ampliar o acesso geográfico e financeiro dos espectadores. Por enxergar o cinema como prática de consumo, e não como direto à 
cultura, o programa não contribui significativamente para a diminuição das desigualdades de acesso e se esquiva de atuar sobre a falta de diversidade do conteúdo. Dessa forma, o CPV não só deixa de alcançar suas metas, mas também ajuda a reforçar modelos e práticas que se mostram prejudiciais à difusão do cinema nacional independente e a um acesso mais universal dos espectadores.

De um ponto de vista mais amplo, a constatação de que as políticas de acesso ainda se concentram primordialmente nas salas tradicionais de exibição revela que, por um lado, tais políticas não acompanham ou aproveitam a expansão de outros formatos de exibição, como o streaming, ${ }^{12}$ e, por outro, não ousam desafiar antigos poderes empresariais para fazer cumprir a função social da televisão aberta, enquanto concessão pública e janela de maior alcance entre os brasileiros, e garantir espaço para uma programação mais plural e menos subjugada aos preceitos do mercado. Além de formular estratégias para que a exibição em salas de cinema possa ser mais equânime, é preciso enxergar que este não é o único e nem mesmo o mais importante espaço de difusão dos filmes ou porta de acesso dos espectadores hoje.

\footnotetext{
${ }^{12}$ Serviços de transmissão e reprodução de dados multimídia pela Internet, que podem ser acessados em televisões com receptores apropriados e em computadores, celulares e outros dispositivos.
} 


\subsection{Referências bibliográficas}

ALBUQUERQUE JR., Durval. Gestão ou gestação pública da cultura: algumas reflexões sobre o papel do Estado na produção cultural contemporânea. In: RUBIM, Antônio e BARBALHO, Alexandre (Orgs.). Políticas culturais no Brasil. Salvador: EDUFBA, 2007, v. 1, p.61-86.

AGENCIA NACIONAL DO CINEMA (ANCINE). Bilheterias - 2002 a 2013. Brasília: Observatório Brasileiro do Cinema e do Audiovisual, 2014. Disponível em $<$ http://oca.ancine.gov.br/media/SAM/DadosMercado/2101.pdf $>$

Filmes Brasileiros com mais de 500.000 Espectadores - 1970 a 2013. Brasília: Observatório Brasileiro do Cinema e do Audiovisual, 2013. Disponível em $<\underline{\text { http://oca.ancine.gov.br/media/SAM/DadosMercado/2105.pdf }>}$

Informe Anual de Mercado 2013 - Distribuição em Salas. Brasília: Observatório Brasileiro do Cinema e do Audiovisual, 2014. Disponível em $<$ http://oca.ancine.gov.br/media/SAM/2013/DistribuicaoSalas/informeanual2013.pdf $>$

Informe Anual de Mercado 2013 - Salas de Exibição. Brasília: Observatório Brasileiro do Cinema e do Audiovisual, 2014. Disponível em $<$ http://oca.ancine.gov.br/media/SAM/2013/SalasExibicao/informe_anual_salasdeexibicao 2013.pdf $>$

. Informe Anual de Mercado 2013 - Vídeo Doméstico. Brasília: Observatório Brasileiro do Cinema e do Audiovisual, 2014. Disponível em $<$ http://oca.ancine.gov.br/media/SAM/2013/ObrasLancadas/informe_videodomestico_201 3.pdf $>$

Informe Anual de Mercado 2013 - TV Paga. Brasília: Observatório Brasileiro do Cinema e do Audiovisual, 2014. Disponível em $<\underline{\text { http://oca.ancine.gov.br/media/SAM/2013/Programacao/InformeTVPaga2013.pdf }>}$

Informe Anual de Mercado 2013 - TV Aberta. Brasília: Observatório Brasileiro do Cinema e do Audiovisual, 2014. Disponível em $<$ http://oca.ancine.gov.br/media/SAM/2013/MonitoramentoProgramacao/informetvaberta2 013.pdf $>$

Informe Anual Preliminar 2014 - Salas de Exibição. Brasília: Observatório Brasileiro do Cinema e do Audiovisual, 2015. Disponível em $<$ http://oca.ancine.gov.br/media/SAM/Informes/2014/Informe_anual_preliminar_2014_Ar quivodePublicacao.pdf $>$ 
- Listagem de Filmes Brasileiros Lançados - 1995 a 2013. Brasília: Observatório Brasileiro do Cinema e do Audiovisual, 2014. Disponível em $<$ http://oca.ancine.gov.br/media/SAM/DadosMercado/2102 12112014.pdf $>$

. Mapeamento Salas de Exibição. Brasília: Observatório Brasileiro do Cinema e do Audiovisual, 2011. Disponível em <http://www.ancine.gov.br/media/ SAM/Estudos/Mapeamento_Salas_Exibicao_errata.pdf $>$

- Mapeamento TV Aberta. Brasília: Observatório Brasileiro do Cinema e do Audiovisual, 2011. Disponível em $<$ http://www.ancine.gov.br/media/SAM/Estudos/ Mapeamento_TVAberta_Publicacao.pdf $>$

. Mapeamento TV Paga. Brasília: Observatório Brasileiro do Cinema e do Audiovisual, 2011. Disponível em $<$ http://www.ancine.gov.br/media/SAM/Estudos/ Mapeamento_TvPaga_Publicacao.pdf>

. Mapeamento Vídeo Doméstico. Brasília: Observatório Brasileiro do Cinema e do Audiovisual, 2011. Disponível em < $<$ ttp://www.ancine.gov.br/media/SAM/Estudos/ Mapeamento_VideoDomestico_Publicacao.pdf $>$

. Quadro evolutivo com valores de fomento direto - 2003 a 2012. Brasília: Observatório Brasileiro do Cinema e do Audiovisual, 2013. Disponível em $<$ http://oca.ancine.gov.br/media/SAM/DadosMercado/2801-25032013.pdf $>$

AUTRAN, Arthur. O pensamento industrial cinematográfico brasileiro. Campinas: Unicamp, 2004.

O cinema brasileiro contemporâneo diante do público e do mercado exibidor. Significações: Revista de Cultura Audiovisual. São Paulo: Annablume. v. 32, p.119-136, 2009.

BAHIA, Lia. Uma análise do campo cinematográfico brasileiro sob a perspectiva industrial. Niterói: UFF, 2009.

. Majors e Globo filmes: uma parceria de sucesso no cinema nacional. Estudos de Cinema e Audiovisual Socine, São Paulo, v. 10, p.135-149, 2010.

BAPTISTA, Nair. Estado e cinema na Venezuela: as políticas cinematográficas no Governo Chávez. Brasília: UnB, 2012.

BARBALHO, Alexandre. Textos nômades: política, cultura e mídia. Fortaleza: Banco do Nordeste do Brasil, 2008. 144p.

BARONE, João Guilherme. Exibição, crise de público e outras questões do cinema brasileiro. Sessões do imaginário: cinema, cibercultura, tecnologias da imagem. Porto Alegre: Famecos/PUCRS, n. 20, p.6-11, dez/2008. 
BOLAÑO, C. R. S.; MANSO, A. C. Por uma economia política do audiovisual brasileiro: Cinema, televisão e o novo modelo de regulação da produção cultural. In: MELEIRO, Alessandra. Cinema e Economia Política. São Paulo: Escrituras editora, 2009, p.87-100.

BOLAÑO, C. R. S.; MASTRINI, G.; HERSCOVICI, A. Economia Política da Comunicação e da Cultura: uma apresentação. In: Globalización y monopolios en la comunicación en América Latina. Buenos Aires: Biblos, 1999. 1ed. v. 1, p.9-25.

BORGES, Danielle. A retomada do cinema brasileiro: uma análise da indústria cinematográfica nacional de 1995 a 2005. Barcelona: Universidade Autônoma de Barcelona, 2007.

BOSI, Ecléia. Cultura de massa e cultura popular: leitura de operárias. Petrópolis, 1981. 5ed.

BOTELHO, Isaura. Políticas culturais: discutindo pressupostos. In: NUSSBAUMER, Gisele (org.). Teorias e políticas da Cultura: visões multidisciplinares. Salvador: EDUFBA, 2007, p.171-180.

BOURDIEU, Pierre; DARBEL, Alain. O amor pela arte: os museus de arte na Europa e seu público. São Paulo: Edusp/Zouk, 2007.

BRASIL. Agência Nacional do Cinema. Instrução Normativa $n^{0} 77$, de 7 de outubro de 2008. Estabelece as normas gerais para a execução do programa de fomento à universalização do acesso às obras audiovisuais cinematográficas brasileiras de longametragem no segmento de mercado de salas de exibição. Diário Oficial da União, Brasília, 9 out. 2008 .

BRASIL. Presidência da República. Lei n. 8.313, de 23 de dezembro de 1991. Institui o Programa Nacional de Apoio à Cultura (Proac) e dá outras providências. Diário Oficial da União, Brasília, 24 dez. 1991.

BRASIL. Presidência da República. Lei n. 8.685, de 20 de julho de 1993. Cria mecanismos de fomento à atividade audiovisual e dá outras providências. Diário Oficial da União, Brasília, 21 jul. 1993.

BRASIL. Presidência da República. Lei 12.485, de 12 de setembro de 2011. Dispõe sobre a comunicação audiovisual de acesso condicionado e dá outras providências. Diário Oficial da União, Brasília, 13 set. 2011.

BRASIL. Presidência da República. Lei 12.599, de 23 de março de 2012. Institui o Programa Cinema Perto de Você e dá outras providências. Diário Oficial da União, Brasília, 26 mar. 2012.

BRASIL. Presidência da República. Medida Provisória n. 2228-1, de 6 de setembro de 2001. Diário Oficial da União, Brasília, 10 set. 2001.

BRASIL. Receita Federal do Brasil. Instrução Normativa $n^{0} 1.446$, de 17 de fevereiro de 2014. Dispõe sobre a aplicação do Regime Especial de Tributação para Desenvolvimento 
da Atividade de Exibição Cinematográfica (Recine). Diário Oficial da União, 18 fev. 2014.

BRASIL. Economia e política cultural: acesso, emprego e financiamento. Brasília: Ministério da Cultura, 2007.

BRITTOS, V. C.; BOLAÑO, C. R. S.; ROSA, A. M. O. O GT Economia política e políticas de comunicação da Compós e a construção de uma epistemologia crítica da comunicação. In: XIX Encontro Anual da Compós, 2010, Rio de Janeiro.

CALABRE, Lia. Políticas culturais no Brasil: balanço e perspectivas. In: RUBIM, Antônio; BARBALHO, Alexandre (Orgs.). Políticas culturais no Brasil. Salvador: EDUFBA, 2007, v. 1, p.87-108.

CAMARGOS, Carla. Produção audiovisual independente e televisão: a luta pelo espaço de exibição. Brasília, UnB: 2001.

CARNOY, Martin. Estado e teoria política. Campinas: Papirus, 1988.

CASTRO, M. H. G. de. Políticas públicas: conceitos e conexões com a realidade brasileira. In: CANELA, G. Políticas públicas sociais e os desafios para o jornalismo. São Paulo: Cortez Editora, 2008.

CHALUPE, Hadija. Difusão ou restrição: ações de acessibilidade do audiovisual brasileiro. Estudos de Cinema e Audiovisual Socine, São Paulo, v. 10, p.105-121, 2010a.

. Distribuição: a ponte entre o filme e o espectador. Estudos de Cinema e Audiovisual Socine, São Paulo, v. 11, p.514-529, 2010 b.

IKEDA, Marcelo. O modelo das leis de incentivo fiscal e as políticas públicas cinematográficas a partir da década de noventa. Niterói: UFF, 2011.

COUTINHO, Carlos Nelson. Gramsci: um estudo sobre o pensamento político. Rio de Janeiro: Civilização Brasileira, 2012.

DUARTE, Jorge; BARROS, Antonio. Métodos e técnicas de pesquisa em Comunicação. São Paulo: Atlas, 2006.

DEMO, Pedro. Metodologia científica em ciência sociais. 2. ed. São Paulo: Atlas, 1989.

GATTI, André. Distribuição e exibição na indústria cinematográfica brasileira (19932003). Campinas: Unicamp, 2005. $\overline{2007.113} \mathrm{p}$.

Embrafilme e o cinema brasileiro. São Paulo: Centro Cultural São Paulo,

A exibição cinematográfica: ontem, hoje e amanhã. São Paulo: Centro Cultural São Paulo, 2008. 
GIL, Antonio Carlos. Métodos e técnicas de pesquisa social. São Paulo: Atlas, 2008.

LANDINI, Fernando; COWES, Valeria; D'AMORE, Eliana. Hacia un marco conceptual para repensar la accesibilidad cultural. Rio de Janeiro: Cad. Saúde Pública, 30(2): 231, fev. 2014.

MARSON, Melina. O cinema da retomada: Estado e cinema no Brasil da dissolução da Embrafilme à criação da Ancine. Campinas: Unicamp, 2006.

MATTA, João Paulo. Análise competitiva da indústria cinematográfica brasileira no mercado interno de salas de exibição, de 1994 a 2003. Salvador: UFBA, 2004.

MICHEL, Rodrigo. A indústria cinematográfica no Brasil: análise da produção, distribuição e exibição de filmes nacionais no período 1995-2009. Uberlândia: UFU, 2011.

MOSCO, Vincent. The Political Economy of Communication: rethinking and renewal. Londres: SAGE Publications, 1996.

MOSCO, Vincent. La Economía Política de la Comunicación: una actualización diez años después. Cuadernos de Información y Comunicación, v. 11, p.57-79, 2006.

MOSCO, Vincent. The Political Economy of Communication. Londres: SAGE Publications, 2009. 2 ed.

MOURA, Roberto. Interessa-nos essa nova situação do cinema brasileiro? Estudos de Cinema e Audiovisual Socine, São Paulo, 2010, v. 10, p.122-134.

PORTO, Marta. Cultura para a política cultural. In: RUBIM, Antônio; BARBALHO, Alexandre (Orgs.). Políticas culturais no Brasil. Salvador: EDUFBA, 2007, v. 1, p.157179.

RUA, Maria das Graças. Políticas públicas. Florianópolis: Departamento de Ciências da Administração/ UFSC; Brasília: CAPES:UAB, 2009.

RUBIM, Antônio. Políticas culturais no Brasil: itinerários e atualidade. In: BOLAÑO, César; GOLIN, Cida; BRITTOS, Valério (Orgs.). Economia da arte e da cultura. São Paulo: Itaú Cultural, 2010, p.51-71.

. Políticas culturais: entre o possível e o impossível. In: NUSSBAUMER, Gisele (Org.). Teorias e políticas da cultura. Salvador: EDUFBA, 2007. p.139-158.

RUY, Karina. Para onde vão nossos filmes: um estudo sobre a circulação do blockbuster nacional no mercado de salas. Porto Alegre: PUCRS, 2011.

SARAVIA, Enrique. Introdução à teoria da política pública. In: SARAVIA, E; FERRAREZI, E. Políticas públicas: coletânea. Brasília: ENAP, 2009, p.21-42. 
SELONK, Aletéia. Distribuição cinematográfica no Brasil e suas repercussões políticas e sociais: um estudo comparado da distribuição da cinematografia nacional e estrangeira. Porto Alegre: PUCRS, 2004.

SIMIS, Anita. A política cultural como política pública. In: RUBIM, Antônio; BARBALHO, Alexandre (Orgs.). Políticas culturais no Brasil. Salvador: EDUFBA, 2007, v. 1, p.133-155.

Cinema e política cinematográfica. In: BOLAÑO, César; GOLIN, Cida; BRITTOS, Valério. Economia da arte e da cultura. São Paulo: Itaú Cultural, 2010, p.137-164.

Estado e Cinema no Brasil. São Paulo: Annablume, 2008. 2 ed. 311 p.

TRAVASSOS, Claudia; MARTINS, Mônica. Uma revisão sobre os conceitos de acesso e utilização de serviços de saúde. Cadernos de Saúde Pública, Rio de Janeiro, v. 20, 2004. p.190-198.

WASKO, J., MURDOCK, G.; SOUSA, H. The Political Economy of Communications: Core Concerns and Issues. In: Wasko, J., Murdock, G.; Sousa, H. (orgs.) The Handbook of Political Economy of Communications. Malden \& Oxford: Wiley-Blackwell, 2011.

WASKO, J. La Economía Política del cine. Cuadernos de Información y Comunicación, v. 11, p.95-110, 2006.

\subsection{Entrevistas}

KAUFMANN, Selmo. Coordenador de Infraestrutura e Projetos Especiais da Ancine. Rio de Janeiro, abr. de 2014. Entrevista concedida a Milena Times.

BASÍLIO, Vanessa. Assistente administrativa do Cinesystem Imperatriz. Imperatriz, abr. de 2014. Entrevista concedida a Milena Times.

SANTOS, Patrícia. Gerente do Cinesystem Hortolândia. Hortolândia, abr. de 2014. Entrevista concedida a Milena Times.

ARAGÃO, Rosana. Assistente administrativa do Cine 10 Sulacap. Rio de Janeiro, abr. de 2014. Entrevista concedida a Milena Times.

GAMBARIN, Jane. Gerente de expansão da Rede Cinesystem. Maringá, set. de 2013 e abr. de 2014. Entrevista concedida, via e-mail, a Milena Times. 


\subsection{Páginas eletrônicas}

www.ancine.gov.br

oca.ancine.gov.br

fsa.ancine.gov.br

cinemapertodevoce.ancine.gov.br

www.cultura.gov.br/audiovisual/secretaria

www.filmeb.com.br

www.globofilmes.globo.com

samukaitz.blogspot.com 
Apêndice 1 - Programação de jul/2013 a jun/2014 (em quantidade de semanas em cartaz)

\begin{tabular}{|c|c|c|c|c|c|c|}
\hline TÍTULO & ORIGEM & GÊNERO & ANO & $\begin{array}{l}\text { Cinesystem } \\
\text { Imperatriz }\end{array}$ & $\begin{array}{c}\text { Praia de Belas } \\
\text { Porto Alegre } \\
\end{array}$ & $\begin{array}{c}\text { Cinespaço } \\
\text { Granja Viana }\end{array}$ \\
\hline 12 anos de escravidão & EUA/RU & Drama & 2013 & - & - & 1 \\
\hline 13o Distrito & FRA/CAN & Ação & 2014 & 2 & - & - \\
\hline 300 - A ascensão do Império & EUA & Ação & 2014 & 3 & 5 & 5 \\
\hline 47 Ronins & EUA & Ação & 2014 & 2 & 3 & - \\
\hline A culpa é das estrelas & EUA & Romance & 2014 & 4 & 4 & 4 \\
\hline A face do mal & EUA & Terror & 2014 & 1 & - & 1 \\
\hline A gaiola dourada & França & Comédia & 2013 & - & - & 2 \\
\hline A grande beleza & Itália & Drama & 2013 & - & - & 2 \\
\hline A menina que roubava livros & EUA/ALE & Drama & 2014 & 3 & 4 & 2 \\
\hline A música nunca parou & EUA & Drama & 2011 & - & - & 1 \\
\hline A Vida secreta de Walter Mitty & EUA & Aventura & 2013 & 3 & 4 & 4 \\
\hline Adeus, Minha Rainha & FRA/ESP & Drama & 2013 & - & - & 1 \\
\hline Álbum de família & EUA & Drama & 2013 & - & 3 & 4 \\
\hline Alemão & BRA & Drama & 2014 & 3 & 4 & 3 \\
\hline Amante a domicílio & EUA & Comédia & 2014 & - & - & 2 \\
\hline Amazônia & BRA/França & Aventura & 2014 & - & - & 1 \\
\hline Aposta máxima & EUA & Suspense & 2013 & - & - & 4 \\
\hline As aventuras de Peabody \& Sherman & EUA & Animação & 2014 & 4 & 4 & 4 \\
\hline As bem-armadas & EUA & Comédia & 2013 & - & 3 & 2 \\
\hline Até que a sorte nos separe 2 & BRA & Comédia & 2013 & 6 & 6 & 5 \\
\hline $\begin{array}{l}\text { Atividade paranormal: marcados pelo } \\
\text { mal }\end{array}$ & EUA & Terror & 2014 & 4 & 2 & 2 \\
\hline Aviões & EUA & Animação & 2013 & 4 & 4 & 4 \\
\hline Bling Ring - a gangue de Hollywood & EUA & Drama & 2013 & - & - & 2 \\
\hline Blue Jasmine & EUA & Comédia & 2013 & - & - & 5 \\
\hline Bons de Bico & EUA & Animação & 2013 & 5 & 6 & 4 \\
\hline Caçadores de obras-primas & EUA/ALE & Aventura & 2014 & - & 3 & - \\
\hline Caminhando com Dinossauros & EUA/AUS/RU & Animação & 2014 & 4 & 3 & 2 \\
\hline Capitão América 2 - O soldado invernal & EUA & Aventura & 2014 & 6 & 5 & 5 \\
\hline Capitão Philips & EUA & Drama & 2013 & 2 & - & - \\
\hline Carrie: a estranha & EUA & Terror & 2013 & 3 & 2 & - \\
\hline Casa de mãe Joana 2 & BRA & Comédia & 2013 & - & 2 & 2 \\
\hline Cidade Cinza & BRA & Documentário & 2013 & - & - & 1 \\
\hline Círculo de Fogo & EUA & Ação & 2013 & 3 & 3 & 4 \\
\hline Como não perder essa mulher & EUA & Comédia & 2012 & - & 2 & - \\
\hline Como treinar o seu dragão 2 & EUA & Animação & 2014 & 2 & 2 & 2 \\
\hline Confia em mim & BRA & Drama & 2013 & - & 1 & - \\
\hline Confissões de Adolescente & BRA & Comédia & 2014 & 2 & 8 & 5 \\
\hline Copa de Elite & BRA & Comédia & 2014 & - & 4 & 3 \\
\hline Crô - O filme & BRA & Comédia & 2013 & 4 & 4 & 2 \\
\hline De repante pai & EUA & Comédia & 2014 & 1 & 2 & - \\
\hline Divergente & EUA & Ação & 2014 & 3 & 3 & 4 \\
\hline Dose dupla & EUA & Ação & 2013 & - & - & 2 \\
\hline Dragon Ball Z: A batalha dos deuses & Japão & Animação & 2013 & 2 & - & - \\
\hline É o fim & EUA & Comédia & 2013 & - & - & 1 \\
\hline Elysium & EUA & Ficção Científica & 2013 & 4 & 4 & 6 \\
\hline Ender's Game - O jogo do Exterminador & EUA & Ficção Científica & 2013 & 3 & 2 & 3 \\
\hline Entre nós & BRA & Drama & 2014 & - & - & 3 \\
\hline $\begin{array}{l}\text { Eu não faço a menor ideia do que eu tô } \\
\text { fazendo com a minha vida }\end{array}$ & BRA & Comédia & 2013 & - & - & 2 \\
\hline Família do bagulho & EUA & Comédia & 2013 & - & 2 & 1 \\
\hline Flores Raras & BRA & Drama & 2012 & - & 2 & 4 \\
\hline Frances Ha & EUA & Comédia & 2013 & - & - & 1 \\
\hline Frankenstein - Entre anjos e demônios & EUA/AUS & Terror & 2014 & 2 & 2 & 2 \\
\hline Frozen - Uma aventura congelante & EUA & Animação & 2014 & 6 & 7 & 5 \\
\hline Gente Grande 2 & EUA & Comédia & 2013 & 6 & 3 & - \\
\hline Getúlio & BRA & Drama & 2014 & - & 4 & 4 \\
\hline Godzilla & EUA & Ação & 2014 & 3 & 3 & 3 \\
\hline Gravidade & EUA & Ficção Científica & 2013 & 2 & 4 & 9 \\
\hline Guerra Mundial Z & EUA & Ficção Científica & 2013 & 5 & 4 & 4 \\
\hline Hannah Arendt & ALE/FRA & Drama & 2013 & - & - & 3 \\
\hline Hércules & EUA & Aventura & 2014 & 2 & 2 & 1 \\
\hline Homem de Aço & EUA/Canadá/RU & Ação & 2013 & 3 & 3 & 5 \\
\hline Hubble 3D & Canadá & Documentário & 2010 & - & - & 3 \\
\hline Inatividade paranormal 2 & EUA & Comédia & 2014 & 2 & - & 2 \\
\hline Infectados & EUA & Ficção Científica & 2013 & 1 & - & - \\
\hline
\end{tabular}




\begin{tabular}{|c|c|c|c|c|c|c|}
\hline Insonia & BRA & Comédia & 2012 & - & 1 & - \\
\hline Invocação do Mal & EUA & Terror & 2013 & 4 & 4 & 2 \\
\hline Jobs & EUA & Drama & 2013 & - & 2 & 3 \\
\hline Jogos Vorazes: em chamas & EUA & Ação & 2013 & 4 & 5 & 5 \\
\hline Jovem e bela & França & Drama & 2013 & - & - & 2 \\
\hline \begin{tabular}{|l|} 
Julio Sumiu \\
\end{tabular} & BRA & Comédia & 2013 & - & 2 & 2 \\
\hline Justin Bieber's Believe & EUA & Doc & 2014 & 2 & - & - \\
\hline Justin e a espada da coragem & ESP & Animação & 2014 & 2 & - & - \\
\hline Livres por natureza 3D & EUA & Documentário & 2013 & - & - & 5 \\
\hline Malévola & EUA & Fantasia & 2014 & 5 & 5 & 6 \\
\hline Mato sem cachorro & BRA & Comédia & 2013 & 3 & 4 & 5 \\
\hline Meninos de kichute & BRA & Drama & 2014 & 2 & - & - \\
\hline Metallica - Through the never & EUA & Musical & 2013 & - & - & 1 \\
\hline Meu Malvado Favorito 2 & EUA & Animação & 2013 & 6 & 5 & 9 \\
\hline Meu passado me condena & BRA & Comédia & 2013 & 5 & 7 & 6 \\
\hline Minha mãe é uma peça & BRA & Comédia & 2012 & 4 & 3 & 5 \\
\hline Minhocas & BRA/CAN & Animação & 2011 & - & 3 & - \\
\hline Muita calma nessa hora 2 & BRA & Comédia & 2014 & 4 & 5 & 3 \\
\hline Mulheres ao ataque & EUA & Comédia & 2014 & 2 & 3 & 3 \\
\hline Muppets 2 - procurados e amados & EUA & Animação & 2014 & 1 & 1 & - \\
\hline Namoro ou liberdade & EUA & Romance & 2014 & 2 & - & 2 \\
\hline Need for speed - O filme & EUA & Ação & 2014 & 2 & 2 & 2 \\
\hline Ninfomaníaca - Volume 2 & DIN & Drama & 2013 & - & 2 & 5 \\
\hline No limite do amanhã & EUA/AUS & Ação & 2014 & 3 & 3 & 3 \\
\hline Noé & EUA & Aventura & 2014 & 5 & 6 & 6 \\
\hline O Ataque & EUA & Ação & 2013 & 3 & 2 & 2 \\
\hline O capital & França & Drama & 2013 & - & - & 1 \\
\hline O casamento do ano & EUA & Comédia & 2012 & - & 2 & 1 \\
\hline O cavaleiro solitário & EUA & Ação & 2013 & 3 & 3 & 4 \\
\hline O Concurso & BRA & Comédia & 2013 & 2 & 3 & 3 \\
\hline O conselheiro do crime & EUA/RU & Suspense & 2013 & - & 2 & 4 \\
\hline $\begin{array}{l}\text { O espetacular Homem Aranha 2: A } \\
\text { ameaça de Electro }\end{array}$ & EUA & Ação & 2014 & 5 & 4 & 4 \\
\hline O filho de Deus & EUA & Drama & 2014 & 2 & - & - \\
\hline O grande herói & EUA & Drama & 2014 & - & 2 & 1 \\
\hline O herdeiro do diabo & EUA & Terror & 2014 & - & 2 & - \\
\hline O Hobbit: a desolação de Smaug & EUA/NZ & Aventura & 2013 & 3 & 6 & 6 \\
\hline O lobo de Wall Street & EUA & Drama & 2014 & 5 & 4 & 2 \\
\hline O renascimento do parto & BRA & Documentário & 2013 & - & - & 1 \\
\hline O tempo e o vento & BRA & Drama & 2013 & 2 & 7 & - \\
\hline O verão da minha vida & EUA & Comédia & 2013 & - & - & 1 \\
\hline Obsessão & EUA & Suspense & 2013 & - & - & 1 \\
\hline One Direction: This is us & EUA & Doc & 2013 & 2 & 2 & - \\
\hline Operação sombra - Jack Ryan & EUA & Suspense & 2014 & 2 & 2 & - \\
\hline Os Escolhidos & EUA & Terror & 2013 & 2 & 2 & - \\
\hline Os estagiários & EUA & Comédia & 2013 & - & 4 & 4 \\
\hline $\begin{array}{l}\text { Os homens são de marte... E é pra lá que } \\
\text { eu vou }\end{array}$ & BRA & Comédia & 2014 & 3 & 5 & 3 \\
\hline $\begin{array}{l}\text { Os Instrumentos Mortais: Cidade dos } \\
\text { ossos }\end{array}$ & EUA/ALE & Aventura & 2013 & 3 & 2 & 3 \\
\hline Os Smurfs 2 & EUA & Animação & 2013 & 6 & 6 & 7 \\
\hline Os Suspeitos & EUA & Suspense & 2013 & 2 & - & 2 \\
\hline Percy Jackson e o Mar de Monstros & EUA & Aventura & 2013 & 4 & 4 & 4 \\
\hline Philomena & EUA & Drama & 2014 & - & 3 & - \\
\hline Pompeia & EUA/ALE & Ação & 2014 & 3 & 1 & 1 \\
\hline Praia do futuro & BRA/ALE & Drama & 2014 & - & - & 1 \\
\hline $\begin{array}{l}\text { Que estranho chamar-se Federico - Scola } \\
\text { conta Fellini }\end{array}$ & Itália & Documentário & 2014 & - & - & 1 \\
\hline \begin{tabular}{|l|} 
R.I.P.D. Agentes do Além \\
\end{tabular} & EUA & Ação & 2013 & 2 & 1 & - \\
\hline $\begin{array}{l}\text { Red 2: Aposentados e ainda mais } \\
\text { perigosos }\end{array}$ & EUA & Ação & 2013 & 2 & 2 & 3 \\
\hline Riddick 3 & EUA & Ficção Científica & 2013 & 3 & 2 & - \\
\hline Rio 2 & EUA & Animação & 2014 & 8 & 8 & 8 \\
\hline Robocop & EUA & Ação & 2014 & 4 & 5 & 3 \\
\hline Rota de Fuga & EUA & Ação & 2013 & 3 & - & 1 \\
\hline Rush: no limite da emoção & EUA/ALE/RU & Drama & 2013 & 2 & 4 & - \\
\hline S.O.S Mulheres ao mar & BRA & Comédia & 2014 & 3 & 4 & 4 \\
\hline Santo Marcos, goleiro de placa & BRA & Doc & 2013 & 1 & - & - \\
\hline Se puder... Dirija! & BRA & Comédia & 2012 & 2 & 3 & 2 \\
\hline Sem dor, sem ganho & EUA & Comédia & 2013 & - & 2 & - \\
\hline Sem escalas & EUA/FRA & Suspense & 2014 & 3 & - & 3 \\
\hline
\end{tabular}




\begin{tabular}{|c|c|c|c|c|c|c|}
\hline Serra Pelada & BRA & Drama & 2012 & 1 & 2 & 4 \\
\hline Silent Hill - Revelação & EUA/FRA/CAN & Terror & 2013 & - & 2 & 1 \\
\hline Sobrenatural: capítulo 2 & EUA & Terror & 2013 & 2 & 2 & - \\
\hline Somos o que somos & EUA & Terror & 2013 & - & - & 2 \\
\hline Tá chovendo hambúrguer 2 & EUA & Animação & 2013 & 4 & 5 & 6 \\
\hline Tarzan: a evolução da lenda & ALE & Animação & 2014 & 3 & 3 & 2 \\
\hline Tese sobre um homicídio & ARG/ESP & Suspense & 2013 & - & - & 2 \\
\hline Thor: o mundo sombrio & EUA & Ação & 2013 & 6 & 5 & 7 \\
\hline Tinker Bell - Fadas e piratas & EUA & Animação & 2014 & 4 & 3 & 3 \\
\hline Todo Mundo em Pânico 5 & EUA & Comédia & 2013 & 2 & 2 & 1 \\
\hline Toque de mestre & EUA/ESP & Suspense & 2014 & - & 2 & 2 \\
\hline Transcendence - A revolução & EUA & Drama & 2014 & - & 2 & 2 \\
\hline Transformers - A era da extinção & EUA/ China & Ação & 2014 & - & - & 1 \\
\hline Trapaça & EUA & Suspense & 2014 & - & - & 1 \\
\hline Trem noturno para Lisboa & EUA/ ALE/ Suiça & Drama & 2013 & - & - & 4 \\
\hline Truque de Mestre & EUA/FRA & Suspense & 2013 & 2 & 2 & 8 \\
\hline Tudo por um fio & EUA & Comédia & 2014 & - & 1 & - \\
\hline Turbo & EUA & Animação & 2013 & 2 & 2 & 3 \\
\hline Última viagem a Vegas & EUA & Comédia & 2013 & 2 & 3 & 3 \\
\hline Um conto do destino & EUA & Fantasia & 2014 & - & 2 & 2 \\
\hline Um mar de aventuras 3D & EUA/CAN & Documentário & 2009 & - & - & 1 \\
\hline Um Plano Brilhante & FRA/ RU & Comédia & 2014 & - & - & 2 \\
\hline Um time show de bola & ARG/ESP & Animação & 2013 & 3 & 3 & 2 \\
\hline Uma aventura Lego & EUA/AUS & Aventura & 2014 & 4 & 4 & 1 \\
\hline Uma História de Amor e Furia & BRA & Animação & 2013 & - & - & 2 \\
\hline Universidade Monstros & EUA & Animação & 2013 & 6 & 3 & 4 \\
\hline Vendo ou alugo & BRA & Comédia & 2012 & - & 2 & 2 \\
\hline Vizinhos & EUA & Comédia & 2014 & 2 & 2 & 2 \\
\hline Vovô sem vergonha & EUA & Comédia & 2013 & - & 4 & 3 \\
\hline $\begin{array}{l}\text { Walt Disney nos bastidores de Mary } \\
\text { Poppins }\end{array}$ & EUA & Drama & 2013 & - & 2 & 2 \\
\hline Wolverine: Imortal & EUA & Ação & 2013 & 6 & 6 & 6 \\
\hline X-men: dias de um futuro esquecido & EUA & Ação & 2014 & 4 & 6 & 4 \\
\hline & & \multicolumn{2}{|c|}{ TOTAL DE TÍTULOS: } & 97 & 112 & 133 \\
\hline & & \multicolumn{2}{|c|}{ TÍTULOS NACIONAIS: } & 16 & 23 & 23 \\
\hline
\end{tabular}

TOTAL GERAL:

TOTAL NACIONAIS:

TOTAL AMERICANOS: 